\title{
AVALIAÇÃO DA RESISTÊNCIA À FRATURA EM COROAS METALOCERÂMICAS E CERAMOCERÂMICAS UTILIZANDO INFRA-ESTRUTURAS COM E SEM REFORÇO
}

DANIEL EDUARDO BAYARDO-GONZÁLEZ

Dissertação apresentada à Faculdade de Odontologia de Bauru da Universidade de São Paulo, como parte dos requisitos para obtenção do titulo de Mestre em Odontologia, área de Reabilitação Oral. 


\section{AVALIAÇÃO DA RESISTÊNCIA À FRATURA EM COROAS METALOCERÂMICAS E CERAMOCERÂMICAS UTILIZANDO INFRA-ESTRUTURAS COM E SEM REFORÇO}

DANIEL EDUARDO BAYARDO-GONZÁLEZ

Dissertação apresentada à Faculdade de Odontologia de Bauru da Universidade de São Paulo, como parte dos requisitos para obtenção do titulo de Mestre em Odontologia, área de Reabilitação Oral.

Orientador: Prof. Dr. Gerson Bonfante 


\section{Bayardo-González, Daniel Eduardo.}

B34a Avaliação da resistência à fratura em coroas metalocerâmicas e ceramocerâmicas, utilizando infra-estruturas com e sem reforço.

/Daniel Eduardo Bayardo-González. -- Bauru, 2007. 101p. : il. ; $30 \mathrm{~cm}$.

Dissertação. (Mestrado) -- Faculdade de Odontologia de Bauru, Universidade de São Paulo.

Orientador: Prof. Dr. Gerson Bonfante.

Autorizo, exclusivamente para fins acadêmicos e científicos, a reprodução total o parcial desta dissertação/tese, por processos fotocopiadores e outros meios eletrônicos.

Assinatura do autor:

Data: 1 


\section{Daniel Eduardo Bayardo-González}

23 de Agosto de 1981

Guadalajara, Jalisco, México

Nascimento

Filiação

Rubén Eduardo Bayardo Casillas † Evangelina González Gómez

$1999-2004$

Curso de Graduação em Odontologia pelo Centro Universitário de Ciências da Saúde da Universidade de Guadalajara - Jalisco - México

$2003-2004$

Curso de Atualização em Prótese Fixa e Oclusão pelo Centro de Estudos de Posgrado em Odontologia, Guadalajara - Jalisco - México

$2005-2007$

Curso de Pós-Graduação - Mestrado em Reabilitação Oral, pela Faculdade de Odontologia de Bauru Universidade de São Paulo - SP Brasil

Associações

Seminários Odontológicos Latinoamericanos - Seção México

Colégio de Odontólogos Universitários de Jalisco - México 


\section{DEDICATORIA}

\section{A Deus.}

A minha mãe Evangelina, por tudo, me conceber, me cuidar desde meu nascimento, dar apoio, esperança, segurança, ensinar-me tantas coisas, e o mais importante dar-me sempre muito amor.

Ao meu Pai Rubén †, padre por treinta o cuarenta años, amigo de mi vida todo el tiempo, protector de mi miedo, brazo mío, palabra clara, corazón resuelto.

A meus irmãos Rubén, Emmanuel e Alecsia, os parceiros da minha vida e meus melhores amigos.

A Sara Ángela, por todo amor. Me aprendo en ti más que en mi mismo. Eres como un milagro a todas horas, como un dolor sin sitio. Sino fueras mujer fueras mi amigo. Dulce como tu nombre, como un higo, me esperas en tu amor hasta que arribo.

\section{A Sabina†.}

A vocês com todo meu amor, dedico este trabalho. 


\section{AGRADECIMENTOS}

Ao meu Orientador, Prof. Dr. Gerson Bonfante, meu reconhecimento por sua constante paciência e orientação, com que conduziu este trabalho, sempre ajudando nos momentos precisos, dando-me liberdade para conduzir minhas próprias idéias, sinto muito orgulho de ser seu orientado. Pelo apoio, pela confiança serei eternamente grato.

A minha mãe brasileira a Profa. Dra. Jane Elizabeth Kraus pela maneira que me recebeu na sua casa, por todos os ensinamentos que transformaram esta experiência de vida em inúmeros e inesquecíveis momentos agradáveis.

Ao Lic. Francisco Javier De la Vega Álvarez, pelo incentivo e confiança, por acreditar em mim, alicerçado em seu exemplo de determinação e competência, cresceu meu desejo de desenvolvimento e a certeza de que, com trabalho, persistência e fé, realizamos nossos sonhos.

Ao Dr. Luis Fernando Maciel Ramirez, por ter-me acompanhado no caminho e por compartilhar tudo seu conhecimento e sua amizade, a você devo mais que meus conhecimentos. 


\section{AGRADECIMENTOS INSTITUCIONAIS}

A minha Alma Matter, a Universidade de Guadalajara.

A Faculdade de Odontologia de Bauru, da Universidade de São Paulo, na pessoa do seu diretor Prof. Dr. Luiz Fernando Pegoraro, obrigado pelos conhecimentos e experiência transmitidos, seu exemplo de dedicação à profissão são inestimáveis, sendo uma inesgotável fonte de inspiração.

Ao Departamento de Prótese da Faculdade de Odontologia de Bauru (FOBUSP), na pessoa do seu chefe Prof. Dr. Acácio Lins do Valle, pelo apoio que recebi durante todo o curso, por sua constante dedicação.

Ao Centro Universitário de Ciências da Saúde da Universidade de Guadalajara representada pelo ex-reitor, Dr. Raul Vargas.

Ao Chefe do Departamento de Odontologia para a Preservação da Saúde do Centro Universitário de Ciências da Saúde da Universidade de Guadalajara, Dr. Jose Humberto Muñoz López, e os professores Dr. Fernando Moreno Casillas e Dr. Luis Fernando Moreno López.

Ao Chefe do Departamento de Clínicas Odontológicas Integradas do Centro Universitário de Ciências da Saúde da Universidade de Guadalajara, Prof. Ms. Álvaro Cruz González. 
À Coordenadora do curso de Odontologia do Centro Universitário de Ciências da Saúde da Universidade de Guadalajara, Dra. Luz Patrícia Santibañez Escobar.

Ao Coordenador do curso de Técnico em Prótese Dental do Centro Universitário de Ciências da Saúde da Universidade de Guadalajara, Dr. Angel Sánchez Michel.

Ao Presidente internacional dos Seminários Odontológicos Latinoamericanos (SOLA), Prof. Dr. Raul Quezada Arcega.

Ao Comitê Diretivo do Centro de Estudos de Posgrado em Odontologia (CEPO), Dr. Luis Fernando Maciel Ramirez, Dr. Manuel Navarro Herrera, Dr. Gustavo Esqueda Orozco. 


\section{AGRADECIMENTOS A AGENCIAS E PESSOAS}

\section{FINANCIADORAS}

- À Fundação de Amparo à pesquisa do Estado de São Paulo (FAPESP), projeto 2005/04581-1.

- Ao Conselho Nacional de Desenvolvimento Cientifico e Tecnológico (CNPq), Programa de Estudantes-Convênio de Pós-graduação (PECPG).

- Ao Programa de Aperfeiçoamento em Ensino (PAE).

- Lic. Francisco Javier De la Vega Álvarez.

- Sra. Rosa González Gómez.

- Sra. Cecilia González Gómez.

- Q.F.B. Karla Montoya Bayardo.

- Dr. Benito Sánchez.

- Dr. Luis Fernando Maciel Ramírez.

- Sra. Josefina Gómez.

- Profa. Dra. Jane Elizabeth Kraus.

- Sra. Rosa López.

- Familias González Gómez e Bayardo Casillas.

A vocês devo tudo, ter chegado ao Brasil e ter voltado ao meu México com uma formação profissional de qualidade, muito obrigado pela confiança depositada em mim. Meu eterno agradecimento para todos vocês. 


\section{AGRADECIMENTOS}

A todos meus Professores da faculdade de Odontologia de Bauru, especialmente ao Prof. Dr. Paulo César Conti, Prof. Dr. José Henrique Rubo, Prof. Dr. Paulo Martins, Prof. Dr. Carlos Araújo, Prof. Dr. Milton Salvador, Prof. Dr. Vinicius Carvalho, Profa. Dra. Lucimar Falavinha, Prof. Dr. Wellington Bonachella, Prof. Dr. Renato de Freitas, Prof. Dr. Sebastião Luis Aguiar Greghi pelos conhecimentos transmitidos, apoio e confiança oferecida durante o curso.

Ao Prof. Dr. José Mondelli um exemplo de profissionalismo e um ser humano em todas suas atitudes.

Ao Prof. Dr. José Roberto Lauris, pela orientação e paciência na confecção da analise estatística do presente estudo.

Ao Prof. Dr. Ricardo Marins Carvalho, pelo aconselhamento cientifico na obtenção do auxilio FAPESP para o desenvolvimento do presente trabalho.

Ao Prof. Dr. Alberto Consolaro, pelas maravilhosas bem-vindas ao curso de mestrado.

Ao Prof. Dr. Pedro César Garcia de Oliveira, pelo apoio e as sensatas sugestões em este projeto. 
Aos meus amigos e colegas do Mestrado Valeria, Adriana, Gabriela, Flora, Luciana, Ana Paula, Paola, Roman, Thiago, Luis Eduardo, Jefferson, Daniel, Rafael e Fernando, pela amizade e convivência, encorajando-me sempre nos momentos difíceis e presentes nos momentos de alegria. Obrigado por estarem sempre acrescentando para o curso e para minha formação.

Aos meus amigos e colegas do Doutorado Rodrigo, Estevam, Rafael, Patrícia, Kátia, Ayub, Renato, Fukashi, Ricardo, Jefferson, Tatiany, Paulo, Leylha, Luiz Gustavo, Mikaela, Andréa, Marcio Taga, e Lívia, por dividirem os conhecimentos e as experiências. Em particular pela sinceridade e presteza em sempre ajudar, pelo espírito de companheirismo e amizade.

A todos meus amigos em Brasil, especialmente a Juan, Ramiro, Valeria, Leonardo caricoa, Adriano Mondelli, Thiago Bugre, Leonardo chuco, Rogério Pre, Eduardo Picho, Leonardo mineiro, Claudia Danielli, Melissa, Dafna, Fernando Bonfante, Erik, Renzo, Juan Carlos, Neimar Pavarini, Daniel Resende, Vladimir, Juliana, Juan Fernando, Eugenio, Hugo, Leo e Cadu, pela acolhida carinhosa e o apoio constante, minha família brasileira que sempre lembrarei. Amigos para siempre.

Aos funcionários do Departamento de Prótese Claudia e Débora e das clínicas, especialmente à Cleusa, Valquiria, Hebe e Eduardo.

Aos protéticos Reivanildo, Nelson e Marcelo, pela ajuda no desenvolvimento experimental deste trabalho. 
Ao corpo de funcionários da biblioteca, especialmente a Rita, Vera, Valeira, César, Ademir, Ana Paula.

Aos funcionários da Pós-Graduação, especialmente à Giane, Maria Margareth, Ana Letícia e Geyce.

A todos meus amigos no México, em especial a Luis, Jesus, Toño, Carlos, Genaro, Roberto, Jorge Jacome, José Maria, Jorge Barba, Ana Luisa, Alica Carolina, Doria, Julian Casillas, Jorge Chacon, Javier Ramirez, Diego Nuñez, Pablo Andrade, Jesus Mejia, Ernenek Mejia, Mariana Petroni, Raul Hernandez, Armando Barba, Dr. Raul Hernandez, Sra. Ana Luisa Barba Dr. Armando Barba e Diego Espinoza, amigos de toda la vida, amigos para siempre. Ustedes son el mejor vinculo que tengo con mi pasado y con certeza por eso estaremos unidos en el futuro. Es como dice un amigo, ustedes son mas allá del bien y del mal.

A Sra. Josefina Bayardo e ao Sr. Samuel Melendrez.

Aos amigos e colegas no México que sempre estiveram acompanhando meu desenvolvimento no mestrado, Dr. Antonio Sordo, Dr. Roberto Espinosa, Dr. Aníbal Padilla, Mario Quintero e Dr. Enrique Del Castillo, obrigado pela força parceiros. 
Ao laboratório que fabricou os corpos de prova necessários para o desenvolvimento deste estudo, representado pelo Prof. Dr. Jose Gilmar e Paulo Renato.

A todas as pessoas que laboram ou laboraram na clínica de "Odontologia do Desenvolvimento".

A todas as pessoas que de alguma forma contribuíram, diretamente ou indiretamente, para a conclusão deste trabalho, jamais esquecerei de vocês.

MUITO OBRIGADO 


\section{SUMÁRIO}

Lista de figuras $\quad$..............................................................................

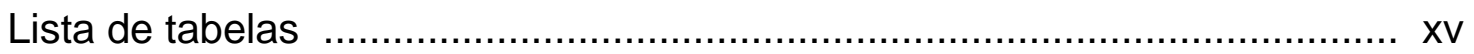

Lista de abreviaturas e símbolos ........................................................ xvi

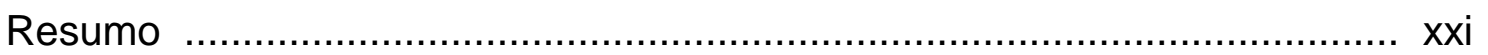

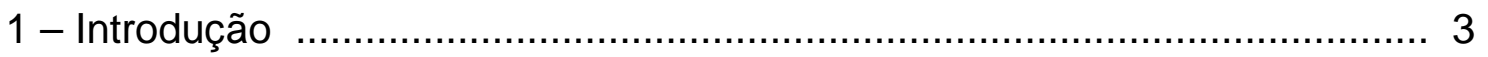

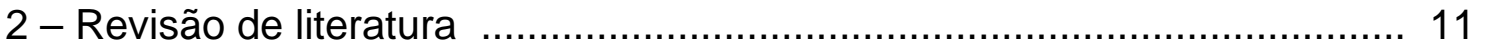

3 - Proposição ................................................................................. 43

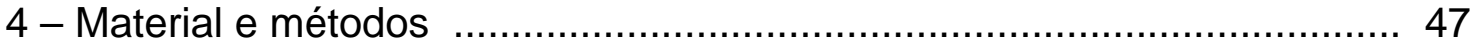

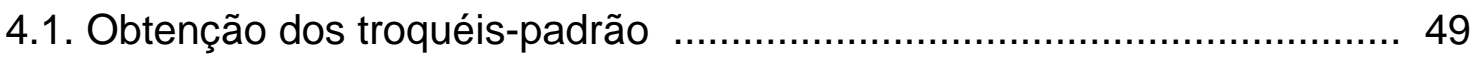

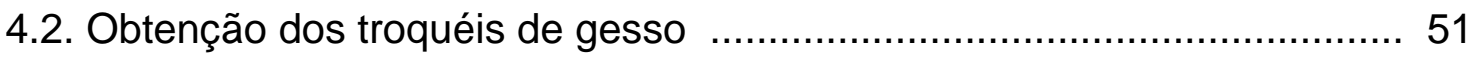

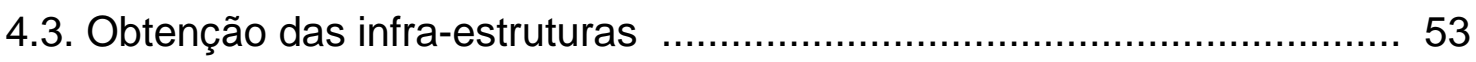

4.3.1. Desenho das infra-estruturas .................................................... 54

4.3.2. Obtenção das infra-estruturas metálicas ....................................... 55

4.3.2.1. Obtenção dos padrões de cera ............................................... 55

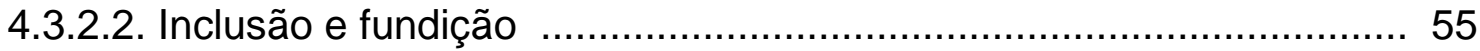

4.3.3. Obtenção das infra-estruturas cerâmicas …................................... 56

4.3.3.1. Preparação da mistura ..................................................... 57

4.3.3.2. Cocção de sinterização no forno Vita Inceramat .......................... 57

4.3.3.3. Cocção de infiltração no forno Vita Inceramat ............................. 58

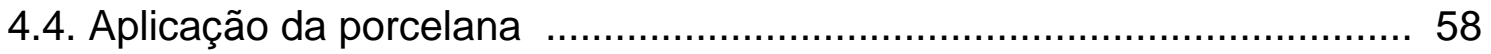

4.4.1. Aplicação e cocção da porcelana sobre as infra-estruturas

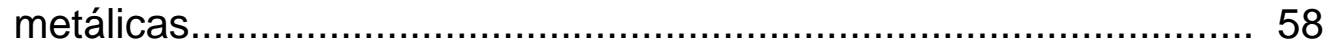

4.4.2. Aplicação e cocção da porcelana sobre as infra-estruturas

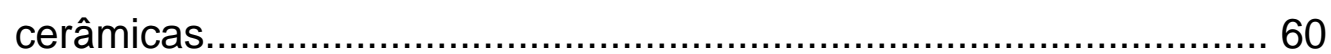

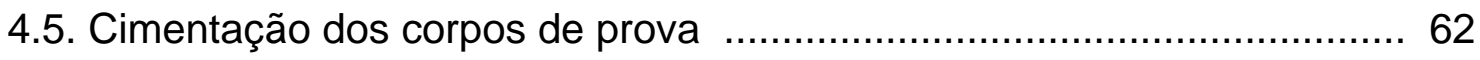

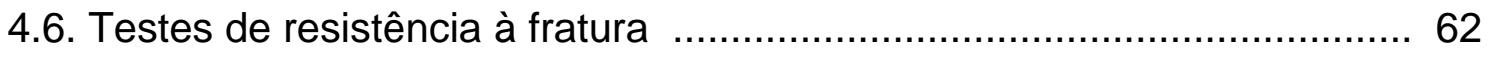

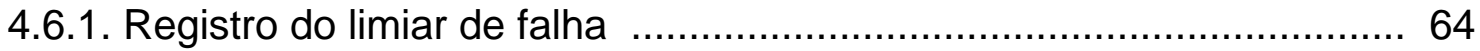

4.6.2. Análise dos corpos de prova fraturados ....................................... 64

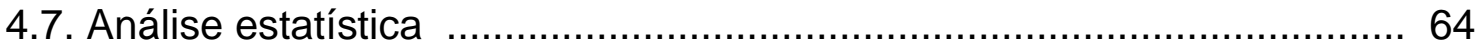

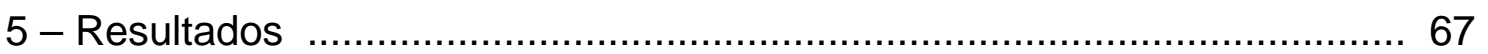


6 - Discussão

75

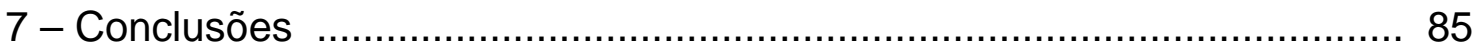

Referências bibliográficas ............................................................... 89

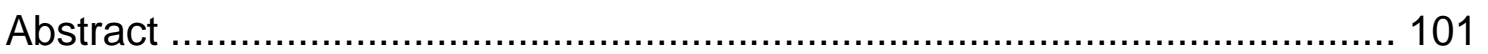




\section{LISTA DE FIGURAS}

Figura 4.1 - Troquéis-padrão metálicos. Vista proximal (a) e vista oclusal (b) de um troquel; quatro troquéis, um para cada grupo experimental (c).

Figura 4.2 - Base da resina acrílica Duralay mostrando pinos que se encaixam nos orifícios na plataforma do paralelômetro modificado (a); base de resina acrílica Duralay fixada na plataforma do paralelômetro (b); e base e troquel-padrão fixados à base de resina Duralay(c).

Figura 4.3 - Paralelômetro modificado com base acrílica encaixada e moldeira no troquel metálico (a); detalhe da carga estática mantida pelos dispositivos para carga (b).

Figura 4.4 - Vista proximal (a) e oclusal (b) de um troquel de gesso tipo IV.

Figura 4.5 - Infra-estruturas metálicas de níquel-cromo com reforço (a, e) e sem reforço $(b, f)$; infra-estruturas cerâmicas In-Ceram Alumina com reforço (c, g) e sem reforço (d, h). Vista proximal (a-d) e vista oclusal (e-h)

Figura 4.6 - Matriz de silicona para padronização da espessura de porcelana

Figura 4.7 - Coroas metalocerâmicas com reforço (a) e sem reforço (b); coroas ceramocerâmicas com reforço (c) e sem reforço (d)... 61 
Figura 4.8 - Base metálica para fixação do troquel metálico (a); parte da máquina de testes universal Kratos com a base metálica acoplada (b); cilindro de aço em contato com o corpo de prova (c); detalhe do cilindro de aço em contato com as duas vertentes internas das cúspides da coroa (d).

Figura 5.1 - Média de resistência à fratura das coroas metalocerâmicas com reforço (Grupo 1) e sem reforço (Grupo 2); e das coroas ceramocerâmicas com reforço (Grupo 3) e sem reforço (Grupo 4) .................................................................. 68

Figura 5.2 - Aspecto das coroas fraturadas. As imagens à esquerda mostram uma das coroas com fratura de cada grupo, em maior aumento. Coroas metalocerâmicas com reforço (a) e sem reforço (b); coroas ceramocerâmicas com reforço (c) e sem reforço (d). 


\section{LISTA DE TABELAS}

Tabela 5.1 Valores de resistência à fratura (kgf) para cada corpo de prova e médias e respectivos desvios padrão para os grupos de coroas metalocerâmicas e ceramocerâmicas, com e sem reforço na infra-estrutura.

Tabela 5.2 - Médias de resistência à fratura $(\mathrm{kgf})$ e respectivos desvios padrão para coroas metalocerâmicas com reforço (Grupo 1) e sem reforço (Grupo 2), e coroas ceramocerâmicas com reforço (Grupo 3) e sem reforço (Grupo 4)

Tabela 5.3 Análise de variância (ANOVA) a dois critérios (1= Material da infra-estrutura: níquel-cromo e In-Ceram Alumina; 2= Presença de reforço: cinta lingual e poste proximal) para os valores de resistência à fratura dos corpos de prova......

Tabela 5.4 Teste de TUKEY para comparações múltiplas entre as médias dos valores de resistência à fratura (kgf) entre todos os grupos: coroas metalocerâmicas com reforço (1), coroas metalocerâmicas sem reforço (2), coroas ceramocerâmicas com reforço (3) e coroas ceramocerâmicas sem reforço (4) 


\section{LISTA DE ABREVIATURAS E SÍMBOLOS}

$\%$

0

$\mathrm{Al}_{2} \mathrm{O}_{3}$

bar

CAD-CAM

CEREC

${ }^{\circ} \mathrm{C}$

DCM

${ }^{\circ} \mathrm{F}$

g

$\mathrm{g} / \mathrm{cm}^{3}$

$\mathrm{kg}$

kgf

$\mathrm{kgf} / \mathrm{seg}$.

Ibs

$\mathrm{lbs} / 20$

$\mu \mathrm{m}$

$\mathrm{mm}$

$\mathrm{mm} / \mathrm{min}$.

$\mathrm{mL}$

$\mathrm{MPa}$

$\mathrm{N}$

$\mathrm{nm}$

$\mathrm{N} /$ seg.

$\mathrm{Ni}-\mathrm{Cr}$

$p$

psi

Vitadur

ZPE

Hi-Ceram
Por Cento.

Graus.

Óxido de Alumínio.

Unidade de pressão.

Computer-aided-design - computer-aided machining.

Ceramic Reconstruction.

Graus Celsius.

Direct ceramic machining.

Graus Fahrenheit.

Gramas.

Gramas por centímetro cúbico.

Quilogramas.

Quilograma força.

Quilograma força por segundo.

Libras.

Unidade de força.

Micrometro.

Milímetro.

Milímetro por minuto.

Mililitros.

Megapascal.

Newton.

Nanômetro.

Newton por segundo.

níquel-cromo.

Nível de significância.

Pound per square inch (Libra por polegada ao quadrado).

Porcelana aluminizada convencional.

Zircônia parcialmente estabilizada.

Cerâmica aluminizada. 


\begin{tabular}{|c|c|}
\hline Optec & Cerâmica reforçada por leucita. \\
\hline Cerestore & Cerâmica aluminizada livre de contrações. \\
\hline Dicor & $\begin{array}{l}\text { Cerâmica de vidro fundível com cristais de fluórmica } \\
\text { tetrassilícica. }\end{array}$ \\
\hline Dicor MGC & $\begin{array}{l}\text { Cristais de fluórmica tetrassilícica em um volume de } \\
\text { aproximadamente } 70 \% \text {. }\end{array}$ \\
\hline IPS Empress & $\begin{array}{l}\text { Vidro ceramizado prensado, contendo aproximadamente } \\
34 \% \text { em volume de leucita. }\end{array}$ \\
\hline IPS Empress 2 & $\begin{array}{l}\text { Vidro ceramizado prensado, contendo aproximadamente } \\
70 \% \text { cristais de dissilicato de lítio. }\end{array}$ \\
\hline In-Ceram & $\begin{array}{l}\text { Infra-estrutura de alumina de maior resistência } \\
\text { Infunsionado com vidro de baixa fusão. }\end{array}$ \\
\hline In-Ceram Alumina & Cerâmica aluminizada e infiltrada por vidro para núcleo. \\
\hline In-ceram Spinell & Porcelana de óxido de magnésia infiltrada por vidro. \\
\hline In-Ceram Zircônia & $\begin{array}{l}\text { Cerâmica de zircônia-alumina, infiltrada por vidros para } \\
\text { núcleo. }\end{array}$ \\
\hline Procera AllCeram & $\begin{array}{l}\text { Cerâmica aluminizada para núcleo sinterizado, prensada a } \\
\text { seco e usinada. }\end{array}$ \\
\hline Lava & $\begin{array}{l}\text { Bloco de zircônia para núcleo parcialmente ou } \\
\text { completamente sinterizado. }\end{array}$ \\
\hline
\end{tabular}


RESUMO 


\section{RESUMO}

As restaurações metalocerâmicas apresentam relatos de sucesso clínico a longo prazo e as características de reforço (cinta lingual e poste proximal) das infra-estruturas metálicas parecem ser de grande importância para este sucesso. Estes reforços freqüentemente estão ausentes nas infraestruturas das restaurações ceramocerâmicas. O objetivo deste estudo foi testar a hipótese nula de que coroas confeccionadas com infra-estruturas cerâmicas com desenho com e sem reforço não resultam em valores de resistência à fratura diferentes de coroas com infra-estruturas metálicas confeccionadas com os mesmos desenhos. Para a realização deste trabalho foram fabricadas 40 coroas, dividas em quatro grupos $(n=10)$ : (1) coroas metalocerâmicas - infra-estrutura com reforço; (2) coroas metalocerâmicas infra-estrutura sem reforço; (3) coroas ceramocerâmicas - infra-estrutura com reforço; e (4) coroas ceramocerâmicas - infra-estrutura sem reforço. Os corpos de prova foram cimentados com ionômero de vidro modificado por resina nos troquéis metálicos e submetidos à análise de resistência à fratura usando uma máquina de teste universal Kratos, a uma velocidade de $0,5 \mathrm{~mm} / \mathrm{min}$. Todos os corpos de prova foram mantidos sob pressão até a fratura. Os resultados de resistência à fratura (kgf) foram submetidos à análise de variância (ANOVA) a dois critérios e ao teste de Tukey. O nível de significância considerado em todas as análises foi de $5 \%(p<0,05)$. Os valores médios de resistência à fratura foram de 237,637 kgf para as coroas metalocerâmicas com infraestruturas com reforço, 171,738 kgf para as coroas metalocerâmicas com infraestruturas com reforço, 127,588 kgf para as coroas ceramocerâmicas com infra-estruturas com reforço e 93,914 kgf para as coroas ceramocerâmicas com infra-estruturas sem reforço, com diferença estatisticamente significante $(p<0,05)$, entre os quatro grupos. As coroas metalocerâmicas com reforço (Grupo 1) apresentaram o maior valor de resistência à fratura e estatisticamente significante, entre todos os grupos. As coroas confeccionadas com infra-estruturas com reforço apresentaram maior resistência à fratura do 
que as confeccionadas sem reforço, tanto nas coroas metalocerâmicas como nas ceramocerâmicas.

Palavras-chave: Coroas ceramocerâmicas. Coroas metalocerâmicas. Desenho da infra-estrutura. Resistência à fratura. Poste proximal. Cinta lingual. 
1 - INTRODUÇÃO 


\section{1 - INTRODUÇÃO}

Considera-se que as primeiras incrustações e coroas de porcelana fundida que tiveram relativo sucesso foram feitas por $\operatorname{LAND}^{39}$, em Detroit (USA), por volta de 1886. LAND tirou uma patente do método de queimar lâminas de platina a fim de fazer uma matriz para a fusão da porcelana com o auxílio de um forno a gás, em 1887.

A porcelana dentária tem várias características muito desejáveis, que favorecem o seu emprego em substituição aos dentes naturais. Entretanto, ela apresenta fragilidade inerente como todos os materiais vítreos e cerâmicos(ANUSAVICE ${ }^{3}$, 2005). Para minimizar essa desvantagem, a literatura ressalta a importância das características no desenho da infra-estrutura, assim como uniformidade da espessura da porcelana de revestimento, que não deve ser menor que 1,0 mm ou maior que 2,0 mm (CHICHE; PINAULT ${ }^{11}, 1994$, DONOVAN; CHEE $^{17}$, 1993, HOBO; SHILLINGBURG ${ }^{29}$, 1973, KUWATA ${ }^{38}$, 1988, MCLEAN et al. $^{52}, 1978$, ROSENSTIEL; LAND; FUJIMOTO ${ }^{78}, 2002$, SOZIO $^{90}, 1977$, STEIN; KUWATA ${ }^{92}, 1977$, WEISS $\left.{ }^{106}, 1977\right)$.

Em 1956 ocorreu um desenvolvimento significante no uso da porcelana fundida com certas ligas de ouro para formar próteses unitárias e fixas. Previamente eram usadas ligas de irídio-platina e paládio, mas a união da porcelana com ligas de ouro permitiu a combinação da estética da porcelana e a ductilidade, força e resistência da liga de ouro (HOBO; SHILLINGBURG $^{29}$, 1973, RAMOS JUNIOR; BATISTA; MIRANDA $\left.{ }^{76}, 1997\right)$.

Em 1974, as infra-estruturas das restaurações metalocerâmicas passaram a utilizar ligas de metal básico, principalmente as não-preciosas de níquel-cromo e cobalto-cromo associadas à porcelana. Este sistema se tornou extremadamente popular quando o preço do ouro se elevou muito em 1980, sendo atualmente as restaurações mais utilizadas (ANUSAVICE ${ }^{3}, 2005$, GREY; PIDDOCK; WILSON ${ }^{23}, 1993$, WEISS $^{106}, 1977$ ).

Dentre os sistemas restauradores utilizados, as restaurações metalocerâmicas apresentam relatos de sucesso clínico a longo prazo (DONOVAN; CHEE ${ }^{17}, 1993$, GARDNER et al. ${ }^{21}, 1997$, JOSEPHSON et al. ${ }^{35}$, 
1985, JOSEPHSON et al. $\left.{ }^{34}, 1991\right)$, e as características de suas infra-estruturas metálicas são de grande importância para este sucesso (CASTELLANI et al. ${ }^{10}$, 1994, CHICHE; PINAULT ${ }^{11}$, 1994, MILLER ${ }^{56}, 1977$, NAYLOR $^{61}, 1992$, THOMPSON; REKOW ${ }^{96}$, 2004). Como principais características das restaurações metalocerâmicas podem ser citadas: tipo de material, módulo de Young, espessura da infra-estrutura e porcelana de revestimento, porosidade, geometria, módulo de elasticidade, rigidez de suporte, coeficiente térmico de expansão, integridade marginal, dureza e desenho da infra-estrutura metálica.

As tradicionais coroas metalocerâmicas satisfazem à demanda da alta resistência requerida pela cavidade oral, mas estas restaurações apresentam deficiência estética, como a presença de sombra do metal na área gengival, assim como reações de hipersensibilidade causadas pelas ligas metálicas (CHRISTENSEN $\left.{ }^{12}, 1994\right)$.

Visando a estética, função e biocompatibilidade dos sistemas restauradores, novas técnicas e materiais foram desenvolvidos afim de substituir as ligas metálicas utilizadas na confecção da infra-estrutura das restaurações metalocerâmicas, gerando diferentes sistemas cerâmicos com reforço de alumina, zircônia e leucita. Assim, as coroas ceramocerâmicas foram criadas e mostraram resultados positivos e similares aos obtidos pelas restaurações metalocerâmicas, além de as superarem no quesito estético (THOMPSON; REKOW ${ }^{96}$, 2004).

Com relação à resistência à fratura das próteses unitárias de porcelana, um avanço significativo foi registrado em 1965, por McLEAN; HUGHES $^{51}$, que introduziram o método que utilizava um núcleo cerâmico aluminizado. Este consistia em uma matriz vítrea com aproximadamente $40 \%$ a $50 \%$ em peso de oxido de alumina $\left(\mathrm{Al}_{2} \mathrm{O}_{3}\right)$.

Os primeiros sistemas com porcelanas reforçadas surgiram na década de 90, tais como: In-Ceram Alumina (Vita $\left.{ }^{\circledR}\right)$, composto por óxido de alumínio infiltrado por vidro; IPS Empress 2 (Ivoclar®), reforçado por cristais de silicato e orto-silicato de lítio; e Procera AllCeram (Nobel Biocare ${ }^{\circledR}$ ), feito de óxido de alumínio sinterizado e prensado (ANDERSSON; ODEN², 1993, HOLAND $^{31}$, 2000, ZENG; ODEN; ROWCLIFFE ${ }^{109}$, 1996).

A pesar de terem sido propostos vários tipos de cerâmica reforçada, as restaurações ceramocerâmicas apresentam friabilidade como principal 
desvantagem, Havendo, portanto, a necessidade de uma infra-estrutura mais resistente (HONDRUM ${ }^{32}, 1992$, NEIVA et al. $\left.{ }^{62}, 1998\right)$.

Para aumentar a resistência da porcelana e inibir a propagação da fratura foram utilizados diferentes materiais e técnicas na confecção da infraestrutura como, por exemplo: a incorporação de um material cristalino, capaz de sofrer uma mudança estrutural quando colocado sob tensão, como acontece com a zircônia parcialmente estabilizada (ZPE), adição de partículas de um material cristalino e tenaz como leucita ou lítio de magnésio (ANUSAVICE ${ }^{3}$, 2005).

Para o sistema In-Ceram os fabricantes recomendam um desenho das infra-estruturas para coroas na região posterior de $0,7 \mathrm{~mm}$ na região oclusal e de 0,5 mm na região circundante (VITA $\left.{ }^{100}, 2005\right)$.

Entretanto, McLEAN ${ }^{45}, 1998$, chamou a atenção para o fato de que, para se obter a resistência necessária para suportar os esforços mastigatórios, as infra-estruturas das coroas ceramocerâmicas, como as feitas de alumina, deveriam apresentar as mesmas características das infra-estruturas das coroas metalocerâmicas.

De acordo com os estudos realizados por GUAZZATO et al. ${ }^{24}, 2001$, não foi encontrada diferença estatisticamente significante na resistência à fratura entre os sistemas com porcelanas reforçadas de alumina e de zircônia. . No entanto, o desempenho clínico das restaurações ceramocerâmicas tem sido desanimador quando comparado com as restaurações metalocerâmicas, especialmente para as coroas e próteses fixas localizadas na região posterior da cavidade oral (NEIVA et al. ${ }^{62}$, 1998). Além disso, a fabricação de coroas ceramocerâmicas apresenta uma técnica altamente sensível e sua limitada resistência à fratura restringe seu uso na clínica (GREY; PIDDOCK; WILSON ${ }^{23}$, 1993).

Desse modo, as coroas metalocerâmicas ainda são as mais utilizadas quando se deseja maior resistência à fratura. Por outro lado, as necessidades clínicas demandam uma coroa que tenha as características estéticas e de biocompatibilidade das coroas ceramocerâmicas e as características de alta resistência à fratura que apresentam as coroas metalocerâmicas (GREY; PIDDOCK; WILSON ${ }^{23}, 1993$ ). 
Visando satisfazer as necessidades do mercado tem ocorrido um rápido desenvolvimento de novos materiais para os sistemas ceramocerâmicos. Tal situação torna difícil à verificação do desempenho clínico das coroas ceramocerâmicas, principalmente a longo prazo, além de que os interesses puramente comerciais das empresas mostram seus produtos sempre com uma visão otimizada, que nem sempre é real (CASTELLANI et al. $\left.{ }^{10}, 1994\right)$.

As porcelanas odontológicas resistem à carga compressiva, mas tendem a sucumbir ao esforço de tração. Por tanto, a infra-estrutura deve ser projetada de forma a que qualquer esforço de tração na porcelana seja minimizado (ROSENSTIEL; LAND; FUJIMOTO ${ }^{78}$, 2002).

Vale ressaltar que muitos dos testes realizados para avaliar a resistência da porcelana à fratura nas restaurações ceramocerâmicas não têm levado em consideração a influência do desenho da infra-estrutura. Geralmente foram testados corpos de prova com formas simples, nos quais a morfologia da porcelana não foi considerada (ORAM; DAVIES; CRUICKSHANKS-BOYD ${ }^{65}$, 1984).

A maioria das restaurações odontológicas fabricadas com cerâmica deve ser projetada de modo a sobrepujar suas desvantagens, isto é, sua baixa resistência à tração, fragilidade ou friabilidade e suscetibilidade a iniciar trincas em superfícies defeituosas. O desenho das infra-estruturas das restaurações deve evitar a exposição da cerâmica a altas tensões de tração, do mesmo modo que deve evitar a contração de tensões em ângulos vivos ou as concentrações ocorridas quando há grandes alterações na espessura (ANUSAVICE ${ }^{3}$, 2005).

Uma revisão de literatura mostrou ausência de trabalhos demonstrando a importância das estruturas de reforço na resistência final (cinta lingual e poste proximal) e esses princípios parecem estar mais assentados em bases clínicas do que em trabalhos de pesquisa. Com freqüência, artigos científicos, de divulgação e livros têm mostrado infra-estruturas sem qualquer estrutura de reforço, que possibilitam apenas a obtenção de coroas com espessuras diferentes de porcelana e, consequentemente, uma perda significativa de resistência à fratura. 
Assim, é fundamental acrescentar pesquisas em técnicas de mensuração das propriedades físicas e químicas dos materiais dentários (TESK; ANUSAVICE ${ }^{95}$, 1988), bem como avaliar a influência das características das infra-estruturas metálicas e cerâmicas na resistência final à fratura para melhorar o potencial de uso destes materiais na odontologia protética e restauradora $\left(\mathrm{SGRO}^{84}, 2002\right)$, principalmente no que diz respeito às estruturas de reforço. 
porcelana Ceramco. O teste de resistência ao impacto foi realizado por meio de um tubo plástico localizado sobre o corpo de prova. Foram utilizadas coroas com dimensões padronizadas, e colocadas sobre os troquéis metálicos. Uma esfera de aço com um peso de $18,9 \mathrm{~kg}$ foi solta sobre o espécime a partir de várias alturas até a fratura da porcelana ocorrer. Os resultados obtidos foram medidos em dina-centímetros: grupo (1) 411.000; grupo (2) 176.000; grupo (3) 117.000; grupo (4) 205.000; grupo (5) 323.000; e grupo (5) 164.000. Os autores concluíram que as técnicas de fusão metal-porcelana são muito resistentes, estáveis e apresentam a melhor técnica, Também relataram que o metal da intra-estrutura apresentou ótimas características físicas e mecânicas no comportamento com porcelana, quando utilizando com uma espessura de 0,5 $\mathrm{mm}$ nas regiões marginais do preparo.

Em 1962, SHELBY ${ }^{85}$ em sua revisão de literatura fez considerações sobre o desenho das restaurações metalocerâmicas. Descreveu os requisitos básicos para se ter êxito nas restaurações metalocerâmicas: (1) dureza do metal e desenho da infra-estrutura; (2) tipo de material; (3) módulo de elasticidade; (4) rigidez do suporte; (5) integridade marginal; (6) preparo; (7) material de cimentação e (8) espessura de película. O autor relatou especificamente que o desenho da infra-estrutura que suporta a porcelana deve ser fabricado de modo a oferecer máxima resistência à porcelana de revestimento e ter qualidades que evitem as forças de torque e cisalhamento.

Em 1965, MUMFORD ${ }^{58}$ escreveu alguns fatores que determinam o sucesso das restaurações metalocerâmicas. Entre esses fatores, indicou 0 desenho da infra-estrutura, espessura da infra-estrutura metálica de 0,33 $\mathrm{mm}$ a 0,5 mm nas áreas de aplicação de porcelana, propriedades físicas das ligas metálicas, distorção da infra-estrutura, cor e técnica de cozimento, combinando, assim, as propriedades de rigidez, resistência à fratura e estética que caracterizam as restaurações metalocerâmicas.

Nessa mesma época, McLEAN; HUGHES ${ }^{51}$, 1965, desenvolveram uma nova cerâmica e uma técnica de aplicação que melhorariam as propriedades mecânicas e de resistência à fratura comparada com as cerâmicas convencionais. Foi utilizado um núcleo cerâmico aluminizado que consistia em uma matriz vítrea com aproximadamente 40\% a 50\% em peso de óxido de alumina $\left(\mathrm{Al}_{2} \mathrm{O}_{3}\right)$. Os resultados obtidos nos testes mecânicos e 
clínicos mostraram que o uso de cristais de alumina como uma fase de reforço na matriz vítrea tornou-a aproximadamente duas vezes mais resistente, quando comparada com as porcelanas dentais convencionais.

Em 1966, STRAUSSBERG; KATZ; KUWATA ${ }^{93}$ em sua revisão de literatura descreveram 0 desenho das infra-estruturas áureas para restaurações metalocerâmicas e relataram a importância da espessura mínima de 0,5 mm na infra-estrutura. Segundo esses autores, a porcelana é resistente à pressão, mas é débil para os esforços de tração, e é necessário desenhar as infra-estruturas com ângulos arredondados para prevenir isto; a infra-estrutura também deve prover um espaço suficiente para-se colocar a porcelana com espessura adequada, assim como apresentar uma cinta metálica de $3 \mathrm{~mm}$ na região lingual.

McLEAN $^{47}$, em 1967, investigou uma prótese confeccionada com porcelana a base de alumina, que apresentava uma alta resistência e não necessitava de preparo para coroa total. Segundo esse autor, uma prótese contendo $97,2 \%$ de alumina e com um pôntico de 4,0 mm de diâmetro, teria um módulo de ruptura médio de 50,490 lbs/pol², que é suficiente para resistir às forças oclusais. Para evitar que ocorressem fraturas na porcelana de revestimento durante a queima, devido à diferença de condutividade térmica desta porcelana e da alumina, foi necessário desenvolver uma cerâmica a base de alumina, contendo vidro para a obtenção da infra-estrutura, pois a fratura depende da formação de qualquer tipo de estresse entre a alumina e a porcelana de revestimento. O desenvolvimento dessa técnica possibilitou a confecção de próteses fixas com infra-estrutura em alumina com um custo aceitável.

Em 1971, CRAIG; EL-EBRASHI; PEYTON ${ }^{14}$ avaliaram a distribuição de estresse nas restaurações e nas estruturas de suporte (infra-estruturas), usaram diferentes desenhos, áreas de carga e magnitudes de força. Os autores utilizaram um modelo fotoelástico, bi-dimensional, para pesquisar a distribuição de estresse em coroas de porcelana com infra-estruturas fundidas de ouro e de porcelana. Foram fabricados seis modelos com diferentes seções vestíbulo-lingual e cinco modelos com diferentes seções mesio-distais na infraestrutura. O estresse foi avaliado em zonas relacionadas na restauração e na infra-estrutura. Os resultados indicaram que as coroas suportadas por ouro 
foram superiores ás suportadas por porcelana e a presença da cinta metálica na região gengival da infra-estrutura reduziu o estado de estresse. Verificaram que a união da porcelana com o ouro deveria localizar-se longe do contacto oclusal; também encontraram que a cobertura completa de porcelana da infraestrutura de ouro não contribuía na resistência, assim como a cinta metálica, na região lingual.

SHILLINGBURG; HOBO; FISHER ${ }^{86}$ em 1973 estudaram a relação entre a configuração do termino do preparo e a estabilidade marginal das restaurações metalocerâmicas durante o processo de cozimento. Foram testados quatro diferentes términos cervicais: (1) chanfrado; (2) chanfrado longo com bisel; (3) ombro com bisel e (4) ombro sem bisel. Para realizar o teste de cozimento foram fabricadas coroas padronizadas por meio de um troquel metálico com forma similar a um incisivo central superior. O desenho das infra-estruturas das restaurações metalocerâmicas tinha uma cinta metálica de $3 \mathrm{~mm}$ na região lingual e espessura de $0,33 \mathrm{~mm}$ a 0,5 mm nas demais áreas; posteriormente, foram aplicadas as diferentes camadas de porcelana e foi realizado o cozimento. Os autores concluíram que os términos com ombro com e sem bisel mostraram menor distorção nas margens labiais quando comparados com os outros grupos. Também observaram que a contração da porcelana durante o cozimento é a primeira causa de distorção da margem, recomendando o aumento da cinta metálica da infra-estrutura nesta região.

Ainda em 1973, HOBO; SHILLINGBURG ${ }^{29}$ descreveram quatro fatores que influíam no sucesso das restaurações metalocerâmicas: (1) a união metal-porcelana; (2) as diferenças entre o ponto de fusão do metal e a temperatura de fusão da porcelana; (3) as diferenças dos coeficientes de expansão térmica e (4) a resistência do metal. Dentro das características da resistência do metal, relataram a importância do desenho, assim como uma espessura adequada no metal da infra-estrutura. Também descreveram a importância do desenho da infra-estrutura metálica nas restaurações metalocerâmicas, que quase sempre é passada por alto. O desenho pode ter um importante efeito no sucesso ou fracasso das restaurações, este não deve ser sacrificado para a obtenção de mais espaço para a porcelana, pois este procedimento não afetara esteticamente a restauração. Os autores citaram três 
características de importância no desenho da infra-estrutura metálica de uma restauração metalocerâmica: (1) a extensão da área a ser coberta pela porcelana; (2) a grossura da cinta metálica marginal e (3) a localização dos pontos de contato. A porcelana deve ter o mínimo de espessura compatível com boa estética. Porcelana com uma espessura uniforme suportada por metal é muito resistente. O mínimo de espessura que pode chegar a ter é de 0,7 mm. Para assegurar adequada resistência e rigidez, a infra-estrutura deverá ter de 0,3 a $0,5 \mathrm{~mm}$ de espessura.

Em 1974, KORNFELD ${ }^{36}$, em sua revisão de literatura descreveu os fundamentos essenciais que uma restauração deve ter para incrementar sua resistência à fratura. São eles: presença da cinta marginal e poste proximal, porcelana com uma espessura uniforme de 1,0 $\mathrm{mm}$ a $1,5 \mathrm{~mm}$, e infra-estrutura metálica com espessura de $0,5 \mathrm{~mm}$. Os pontos de contato oclusal deveriam ocorrer pelo menos a 2,0 mm de distância da linha de junção metal-porcelana.

FARAH; CRAIG $^{18}$, em 1975, estudaram os desenhos de restaurações metalocerâmicas recomendados em artigos previamente publicados por STRAUSSBERG; KATZ; KUWATA ${ }^{93}$, 1966, e NALLY; FARAH; CRAIG $^{60}$, 1971, e relataram que as características da infra-estrutura são de grande importância no sucesso destas restaurações. Para realizar este estudo combinaram os desenhos com um modelo de dente computarizado, aplicando um esquema real de carga para examinar o modelo dental sob esforços de compressão e tração. Os autores concluíram que as superfícies de estresse das coroas de porcelana pura são muito similares as das coroas metalocerâmicas com infra-estruturas em ouro, níquel-cromo ou das coroas de porcelana reforçadas por alumina.

Em 1976, WARPEHA; GOODKING ${ }^{104}$ avaliaram a resistência à fratura de restaurações metalocerâmicas in vitro, utilizando vários desenhos da infra-estrutura metálica e manipulação da porcelana. Para determinar a resistência à fratura foram fabricadas 44 coroas com três diferentes desenhos de infra-estrutura. A resistência à fratura dos corpos de prova foi testada simulando a ação de um pré-molar superior contra um pré-molar inferior, auxiliados pela máquina universal de testes Instron a uma velocidade de 1,27 $\mathrm{mm} / \mathrm{min}$. Os autores concluíram que o desenho da infra-estrutura metálica tem relação significante com a resistência à fratura, sendo a mais importante das 
variáveis, junto com a manipulação dos materiais durante a fabricação da restauração.

MILLER ${ }^{56}$, 1977, descreveu os princípios mecânicos que governam o desenho da maioria das restaurações: (1) rigidez de suporte; (2) resistência à compressão; (3) possuir coeficiente térmico de expansão similar à porcelana de revestimento; (4) permitir biocompatibilidade como o tecido periodontal; (5) oferecer estética e função e (6) facilidade para higienização. O autor propôs, especificamente, para o desenho da infra-estrutura: a utilização de cinta metálica, poste proximal e espessura na infra-estrutura de 0,3 $\mathrm{mm}$ na região vestibular e de 0,5 mm na região lingual e oclusal. Ele acreditava que o desenho da infra-estrutura metálica era fundamental para que qualquer restauração metalocerâmica obtivesse sucesso clínico.

STEIN; KUWATA ${ }^{92}$, em 1977, estudaram cinco elementos das restaurações metalocerâmicas: (1) infra-estrutura metálica; (2) interface metal e porcelana; (3) camada de porcelana opaca; (4) camada da dentina e esmalte da porcelana e (5) superfície externa da porcelana. Os autores descreveram as características do desenho da infra-estrutura metálica, que possibilitam êxito clínico nas restaurações metalocerâmicas. Segundo eles, o desenho da infraestrutura depende diretamente da forma, inclinação e quantidade de desgaste no preparo. Também foi importante colocar a cinta metálica marginal e poste proximal para resistir às forças de distorção, assim como desenhar a infraestrutura para restaurar o perfil de emergência da restauração.

Também em 1977, WEISS ${ }^{106}$ apresentou novos parâmetros para um novo desenho baseado nas propriedades da liga níquel-cromo. Nesse trabalho, o autor mostrou que a eliminação do ouro nas ligas semi-preciosas foi adotada por duas razões: (1) evitar o alto custo e (2) incrementar a resistência. Foi proposta uma espessura de 0,1 a 0,2 $\mathrm{mm}$ para a infra-estrutura metálica em restaurações unitárias, e de 0,2 mm em restaurações múltiplas, assim como uma espessura de 0,2 $\mathrm{mm}$ de opaco e porcelana e cinta metálica lingual de não mais de 1,0 mm. Recomendou que o desenho da infra-estrutura deveria fornecer uma espessura da porcelana uniforme para evitar as fraturas desta, baseado em que a porcelana de cobertura recebe a maioria dos esforços de tração. 
Ainda em 1977, SOZIO $^{90}$ propôs um desenho da infra-estrutura para restaurações metalocerâmicas sem cinta metálica (collarless) na margem cervical da região vestibular, que combina as propriedades físicas favoráveis das coroas metalocerâmicas convencionais e as propriedades estéticas das coroas ceramocerâmicas. Entretanto, o autor relatou que uma das desvantagens dessas coroas é a fratura da porcelana sem suporte metálico na margem cervical da região vestibular.

A seguir, em 1978 McLEAN et al. ${ }^{52}$ descreveram um novo método para unir porcelana a metais preciosos, utilizando camadas finas de óxido. Uma folha de platina é unida à porcelana aluminizada, formando uma câmara protetora, o que reduz o desenvolvimento de microfraturas e aumenta a resistência da coroa. Também melhoro a translucidez da coroa usando espessas camadas de porcelana. Essa técnica permite o uso de cinta de porcelana na margem vestíbulo-cervical.

Em 1980, FAUCHER; NICHOLLS ${ }^{19}$ avaliaram in vitro a magnitude e a localização da distorção marginal durante a cocção da porcelana. Compararam a susceptibilidade da distorção de cada desenho marginal investigado e relacionaram cada um com a extensão do término cervical. Os desenhos comparados foram: (1) chanfrado; (2) ombro e (3) ombro com bisel. Para este estudo foram fabricadas coroas sobre um troquel que simulava 0 preparo de um incisivo central superior. As infra-estruturas das coroas apresentavam espessura de 0,5 mm, exceto na margem vestibular. Posteriormente, foram aplicadas as diferentes camadas de porcelana e realizado o cozimento destas. Os resultados obtidos suportaram a teoria de que colocando, metal adicional na margem gengival, se reforça a margem e evita a distorção marginal.

Alguns anos depois, o desenvolvimento de sistemas de cerâmica pura obtida por meio de uma cristalização vítrea controlada (Dicor) foi apresentado por ADAIR; ROSSMAN ${ }^{1}$, em 1984. O vidro era fundido e injetado em um molde refratário e, subsequentemente, cristalizado para formar o vidro ceramizado Dicor, que possuía cristais de fluórmica tetrassilícica inseridos na matriz vítrea.

Também em 1984, DEHOFF; ANUSAVICE ${ }^{15}$ avaliaram o efeito do desenho da infra-estrutura na distribuição do estresse residual e o 
deslocamento do metal das coroas metalocerâmicas devido ás diferenças na contração térmica. O estresse residual foi calculado por meio de elemento finito. Foram utilizadas combinações de ligas de níquel-cromo e ouro-paládio para fabricar as coroas metalocerâmicas com as seguintes configurações na terminação cervical: chanfrado em lâmina, chanfrado sem colar, ombro com colar e ombro com bisel sem colar. Segundo os, autores a distorção marginal depende diretamente das diferenças de contração térmica metal-porcelana e é insensível ao efeito do desenho da infra-estrutura.

PHILP; BRUKL ${ }^{67}$ (1984) avaliaram in vitro a resistência à fratura de coroas de cerâmica aluminizada convencional, coroas de dupla folha de platina e coroas Cerestore (cerâmica aluminizada). As coroas foram cimentadas nos troquéis de policarbonato com cimento de fosfato de zinco e depois os corpos de prova foram mantidos por 48 horas a 100\% de umidade. A resistência à fratura dos corpos de prova foi testada numa máquina de testes universal Instron, a uma velocidade de $1,0 \mathrm{~mm} / \mathrm{min}$, sendo utilizada uma ponta de aço cilíndrica para distribuir a força. Foram encontrados os seguintes resultados: $195,08 \mathrm{kgf}$ para as coroas Cerestore, 180,30 kgf para as coroas convencionais e 139,81 kgf para as coroas de dupla folha de platina. Aplicando o teste de ANOVA, as coroas Cerestore mostraram os valores mais altos de resistência, mas não foram estatisticamente diferentes dos das coroas de cerâmica aluminizada convencionais. As coroas de dupla folha de platina tiveram os valores menores de resistência, comparadas com os demais sistemas.

Ainda em 1984, COORNAERT; ADRIAENS; DeBOEVER ${ }^{13}$ avaliaram clinicamente, por sete anos, 2.181 restaurações metalocerâmicas com infraestruturas de liga de ouro. Os resultados revelaram que somente 2,3\% das coroas falharam e a maioria (1,8\%) falhou nos primeiros 24 meses. Este estudo clínico mostrou uma excelente longevidade de 97,7\% das próteses unitárias e próteses fixas metalocerâmicas nos primeiros sete anos. Na maioria das preparações foi utilizada uma terminação de bisel e chanfrado. A espessura do metal, do opaco e da porcelana foi de 0,2 a 0,3 $\mathrm{mm}, 0,35 \mathrm{~mm}$ e de 0,65 $\mathrm{mm}$, respectivamente. As razões de falha foram: oclusão ou bruxismo (42,3\%), desenho inadequado da infra-estrutura $(23,1 \%)$, espessura inadequada da infra-estrutura $(13,5 \%)$, desenho inadequado da infra-estrutura mais oclusão 
$(13,4 \%)$ e razões desconhecidas (7,7\%). Na análise não foram incluídas as falhas por cáries, enfermidade periodontal e outras condições patológicas.

Em 1984, ORAM; DAVIES; CRUICKSHANKS-BOYD ${ }^{65}$ avaliaram a resistência à fratura in vitro de cinco sistemas metalocerâmicos e ceramocerâmicos, utilizando corpos de prova que tivessem uma morfologia mais próxima à das coroas dentais. Os corpos de prova foram desenhados com forma cilíndrica, de tamanho aproximado ao de uma coroa. A resistência à fratura dos corpos de prova foi testada na máquina de testes universal Instron a uma velocidade de $0,5 \mathrm{~mm} / \mathrm{min}$ até ocorrer a fratura. Para aplicar a força utilizaram uma folha de alumínio com uma espessura de 1,5 mm. Foram encontrados os seguintes resultados para os corpos de prova dos diferentes grupos testados: $12,4 \pm 6,9$ kgf para o grupo 1 (sistema convencional de porcelana aluminizada); 17,2 $\pm 3,8 \mathrm{kgf}$ para o grupo 2 (sistema ativado de folha de platina); 18,8 $\pm 2,8 \mathrm{kgf}$ para o grupo 3 (sistema Sandblasted de folha de

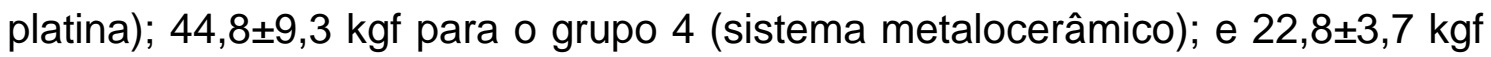
para o grupo 5 (sistema de folha metálica preciosa estampada). Os autores encontraram que o grupo de coroas metalocerâmicas apresentou valores mais altos de resistência comparados com os outros grupos, devido em parte à alta resistência da porcelana e, em parte, pela localização da porcelana longe das áreas de maior estresse.

Para comparar a resistência à fratura in vitro de coroas de cerâmica aluminizada convencional, coroas ceramocerâmicas Cerestore e coroas metalocerâmicas, JOSEPHSON et al. $^{35}$, 1985, testaram dezoito coroas colocando a mesma força em sentido oclusal. Obtiveram os seguintes resultados: 453,62 kgf para as coroas metalocerâmicas, 212,44 kgf para as coroas Cerestore e 117,03 kgf para as coroas de cerâmica aluminizada convencional. Os resultados foram submetidos a análise de variância e verificou-se que as coroas Cerestore foram significativamente menos resistentes que as coroas metalocerâmicas, sendo estas duas vezes mais resistentes.

No ano de 1986, MARKER; GOODKIND; GERBERICH ${ }^{43}$ compararam a resistência à compressão de infra-estruturas fabricadas com ligas de metais preciosos e não-preciosos, utilizando três desenhos diferentes: (1) cobertura de porcelana nas cúspides vestibulares; (2) cobertura de 
porcelana até o sulco central e (3) cobertura completa de porcelana. Cento e trinta e cinco coroas metalocerâmicas foram fabricadas. Neste estudo, três ligas foram utilizadas para fabricar as infra-estruturas, uma de metal precioso (Olympia) e duas de metais não preciosos (Rexillium III e Talladium). As restaurações foram cimentadas nos troquéis e testada a resistência à fratura por compressão na máquina de testes universal Instron. Obtiveram-se os seguintes resultados para a liga Olympia: $18,59 \mathrm{kgf}$ com o desenho 1, 16,78 kgf com o desenho 2 e 16,78 kgf com o desenho 3. Com o uso da liga Rexillium III os resultados foram: 17,23 kgf com o desenho 1, 16,32 kgf para o desenho 2 e 16,32 kgf para o desenho 3. A liga Talladium apresentou os seguintes valores: 22,46 kgf com o desenho 1, 18,32 kgf com o desenho 2 e 21,89 kgf com o desenho 3 . Os autores encontraram que as coroas com o desenho número 1 foram as mais resistentes quando comparados com os desenhos números $2 \mathrm{e}$ 3. Concluíram que as propriedades físicas e mecânicas do metal e a localização do estresse residual na união metal-porcelana tem um efeito maior na resistência a fratura quando comparados com o desenho da infra-estrutura.

Em 1987, STEIN ${ }^{91}$ realizou uma revisão de literatura onde descreveu o colar metálico vestibular como a forma ideal em termos de selamento marginal, saúde periodontal e rigidez durante a cimentação.

Em 1987, McLEAN; KEDGE ${ }^{53}$ avaliaram a resistência de vários sistemas cerâmicos. Nenhum dos sistemas cerâmicos estudados igualou a resistência dos sistemas metalocerâmicos e o uso deles na região posterior apresentou algumas limitações. Dentro dos sistemas cerâmicos, as coroas de porcelana aluminizada e as coroas de porcelana unidas a uma folha de platina foram preferidas pela sua fácil produção, baixo custo, estética e resistência. Os autores descreveram que a espessura ideal para uma infra-estrutura de porcelana pura em áreas onde houvesse concentração de cargas deveria ser de pelo menos 1,0 mm, sendo que em áreas estéticas poderia ser reduzida até 0,3 mm. Também indicaram a confecção de uma cinta de reforço nas regiões cervical e lingual da infra-estrutura, como uma forma de aumentar a resistência, da mesma forma que é feito nas infra-estruturas metálicas. Segundo esses autores, as falhas na resistência de coroas ceramocerâmicas podem ser atribuídas ao material, já que os dentistas e técnicos em prótese acreditam que espessuras de 0,3 $\mathrm{mm}$ a 0,5 mm na infra-estrutura cerâmica teriam o mesmo 
desempenho que o das infra-estruturas metálicas. Concluíram que abordando o conhecimento do desenho para infra-estruturas de cerâmica reduze-se a maioria dos fracassos das restaurações.

No ano seguinte, KUWATA ${ }^{38}$ descreveu os requisitos morfológicos para restaurações metalocerâmicas. Dentre eles podem ser mencionados: (1) a porcelana em conexão com a infra-estrutura metálica deve ter espessura uniforme. Como a porcelana tem uma baixa resistência à tensão e baixa elasticidade, a menos que seja adequadamente suportada pela infra-estrutura, ela não resistirá às forças mastigatórias; (2) a porcelana deve ter uma espessura mínima em todas as áreas de maior estresse oclusal, porque a fratura desta é mais freqüente na região cervical, áreas das pontas das cúspides e em outras regiões fracas da restauração; (3) presença de uma cinta metálica na região cervical para diminuir o efeito de pressão, pois ela aumenta a resistência à fratura da restauração; (4) o desenho da infra-estrutura de metal deve ser projetado de forma a converter as forças oclusais tencionais exercidas sobre a porcelana em forças compressivas.

Em 1989, BERGER ${ }^{6}$ propôs alguns elementos de importância na resistência e estética final das restaurações metalocerâmicas, tais como, 0 enceramento diagnóstico, desenho da infra-estrutura e espaço suficiente para a porcelana, para se obter uma restauração com os requerimentos fisiológicos, estéticos e de resistência à fratura.

Ainda no ano 1989 , McLEAN ${ }^{50}$ propôs que as seções com menos de $1 \mathrm{~mm}$ de espessura de porcelana nas coroas ceramocerâmicas de alumina deveriam ser evitadas, e idealmente o dentista deveria obter secções de 1,5 $\mathrm{mm}$.

DICKINSON et al. ${ }^{16}, 1989$, avaliaram in vitro a resistência à fratura de coroas ceramocerâmicas fabricadas com porcelana aluminizada do sistema Cerestore e do sistema Dicor utilizando. Para determinar a resistência à fratura fabricaram quinze coroas de cada grupo, obtidas a partir de um troquel-padrão. Dez coroas de cada sistema foram cimentadas nos troquéis metálicos. Em seguida, elas foram submetidas à pressão com o auxílio de uma máquina de testes universal Instron até ocorrer à fratura catastrófica delas. Não foi encontrada diferença significativa significante na resistência à fratura nos três sistemas testados Entretanto, sete de dez coroas Cerestore mostraram um 
padrão de fratura em duas fases: fratura inicial seguida por fratura catastrófica. As outras coroas apresentaram uma única fase de fratura: fratura catastrófica junto com a fratura inicial.

Ainda em 1989, CAMPBELL ${ }^{9}$ avaliou a resistência flexural de quatro sistemas cerâmicos restauradores (Dicor, Optec, Hi-Ceram e Cerestore e três sistemas restauradores metalocerâmicos (Jelenko O, Olympia e Rexillium III) com e sem aplicação de porcelana. Para determinar a resistência flexural foram fabricados corpos de prova com as seguintes dimensões: $20 \mathrm{~mm}$ de comprimento por 2,5 mm de largura, que foram submetidos à fratura utilizando o aparelho de carga de três pontos com o auxílio de uma máquina de testes universal. Análise de variância (ANOVA) e teste de Tukey demonstraram que a liga Rexillium III com aplicação de porcelana foi estatisticamente mais resistente que todos os demais grupos, exceto a liga Olympia e a infraestrutura New Cerestore sem aplicação de porcelana. Os autores concluíram que a rigidez e a espessura do material de base da porcelana têm um papel essencial na resistência flexural da restauração.

MCLEAN $^{48}$, 1990, descreveu as causas de insucesso das restaurações odontológicas. As restaurações ceramocerâmicas, em particular, são propensas a falhar em preparos retentivos, curtos ou excessivos. As restaurações de cerâmica pura falham dependendo das microfraturas presentes na superfície da margem e não devem ser indicadas quando existe alto estresse oclusal. Diferentemente, as restaurações metalocerâmicas apresentam maior resistência ao estresse oclusal. A infra-estrutura metálica, além de reforçar a porcelana e reduzir as fraturas por tensão, protege a superfície interna da porcelana contra o fracasso mecânico devido à profundidade das microfraturas. O autor concluiu que as características das restaurações metalocerâmicas são as únicas que se ajustam idealmente para resistir ao estresse oclusal máximo, na maioria das condições clínicas. Por sua vez, as restaurações ceramocerâmicas devem ser indicadas exclusivamente por razões estéticas; deve-se evitar sua indicação em áreas de maior estresse oclusal como na região posterior da cavidade oral.

Em 1990, um vidro ceramizado prensado, (IPS Empress) contendo aproximadamente $34 \%$ em volume de leucita, foi lançado no mercado. Esta cerâmica apresentava uma resistência e adaptação marginal semelhante ao do 
vidro ceramizado Dicor, mas sem a necessidade de um tratamento de cristalização especializado. Mais tarde, um vidro ceramizado prensado (IPS Empress 2), mas resistente à fratura e que continha aproximadamente $70 \% \mathrm{em}$ volume de cristais de disilicato de lítio foi desenvolvido no final desse mesmo ano (ANUSAVICE $\left.{ }^{3}, 2005\right)$.

Ainda em 1990, HOJJATIE; ANUSAVICE ${ }^{30}$ afirmaram que devido ao grande número de falhas em coroas de porcelana pura em dentes posteriores, estas restaurações somente deveriam ser indicadas para dentes anteriores, até que se obtenha progresso significativo para melhorar o desenho, a composição e as condições de processamento dos materiais utilizados na sua confecção.

Em 1991, JOSEPHSON et al. ${ }^{34}$ avaliaram a resistência à fratura in vitro de coroas convencionais de porcelana aluminizada e dos sistemas ceramocerâmicos, Dicor e Renaissance, comparativamente ás coroas do sistema Cerestore. As coroas metalocerâmicas foram utilizadas como grupo controle. Para determinar a resistência à fratura, os autores utilizaram a metodologia e equipamento reportado num prévio estudo ${ }^{34}$. Encontraram que as coroas metalocerâmicas foram as mais resistentes aos esforços de fratura que as coroas convencionais de porcelana aluminizada. Os resultados encontrados para resistência à fratura foram de 323,56 kgf para as coroas metalocerâmicas, 214,69 kgf para as coroas do sistema Renaissance, 186,57 kgf para as coroas do sistema Dicor, 127,52 kgf para as coroas do sistema Cerestore e para as coroas convencionais de porcelana aluminizada, 106,82 kgf. Comentaram, ainda, que as coroas dos sistemas Renaissance e Dicor poderiam ser utilizadas em algumas situações na região posterior da cavidade oral.

NAYLOR ${ }^{61}$, em 1992, descreveu as características e funções das infra-estruturas das restaurações metalocerâmicas. Dentre elas, as mais importantes são: (1) o mínimo de espessura da infra-estrutura deve ser de 0,3 $\mathrm{mm}$ a 0,5 mm, dependendo da liga utilizada; a infra-estrutura deve ter uma espessura suficiente para resistir à flexão ou deformação quando colocada em função e as diferentes espessuras da infra-estrutura proverão resistência e suporte da porcelana; (2) a infra-estrutura deverá ser desenhada para restaurar o contorno original do dente em sua forma e função; (3) a infra-estrutura metálica deverá repor a estrutura dental perdida para obter uma espessura 
uniforme da porcelana. A espessura da porcelana varia de acordo com as diferentes áreas da restauração, por exemplo, no terço gengival seria ideal uma espessura de 1,0 mm e para obter uma dimensão ideal na área incisal ou oclusal, a espessura seria de 1,5 a 2,0 mm. O autor descreveu que em situações de espessura maior que 2,0 mm, a restauração poderia fracassar.

LUND; BARBER ${ }^{40}$, 1992, avaliaram o efeito do desenho da infraestrutura na resistência à fratura de coroas metalocerâmicas da região posterior, in vitro. Compararam a resistência de quatro desenhos propostos na literatura: (1) cobertura de porcelana na região vestibular; (2) cobertura de porcelana na região vestibular e cúspide com mínimo suporte oclusal; (3) cobertura de porcelana vestibular e oclusal até a fossa central e (4) cobertura de porcelana vestibular e oclusal total. Confeccionaram um troquel metálico simulando o preparo de um segundo pré-molar inferior. As coroas foram cimentadas com fosfato de zinco no troquel e, a seguir, submetidas à pressão axial sobre a superfície da cúspide vestibular com o auxílio de uma máquina de testes universal Instron. Os resultados obtidos para a resistência à fratura dos diferentes grupos foram: $223 \mathrm{~kg}$ para o desenho de cobertura de porcelana na região vestibular; $117 \mathrm{~kg}$ para o desenho de cobertura de porcelana na região vestibular e cúspide com mínimo suporte oclusal; $132 \mathrm{~kg}$ para o desenho de cobertura de porcelana vestibular e oclusal até a fossa central; e 108 kg; cobertura de porcelana vestibular e oclusal total. Os autores concluíram que o desenho da infra-estrutura de coroas metalocerâmicas com cobertura de porcelana na região vestibular apresentou os valores mais altos de resistência à fratura apresentado diferença estatisticamente significante entre os outros três grupos.

Em 1992, PRÖBSTER; DIEHL ${ }^{73}$ apresentaram o sistema In-Ceram, que combina os processos de sinterização e infiltração por vidro para se obter uma infra-estrutura cerâmica. Partículas de óxido de alumínio são sinterizadas, formando uma estrutura porosa que será infiltrada por vidro fundido. A combinação destes dois processos dá ao material, segundo os autores, suas excelentes propriedades. O processo de sinterização acontece praticamente sem contração, provendo boa adaptação marginal, enquanto que a infiltração pelo vidro não deixa porosidades, resultando em alta resistência. O artigo 
descreveu os procedimentos técnicos e clínicos do sistema, além de discutir indicações, resistência flexural e integridade marginal.

Também em 1992, PRÖBSTER ${ }^{70}$ avaliou a resistência à compressão in vitro de dois novos sistemas de coroas ceramocerâmicas, InCeram e IPS Empress, comparando-os com coroas metalocerâmicas que utilizavam infra-estruturas fabricadas com níquel-cromo. Obteve-se um troquel de cobalto-cromo preparado com as características de um incisivo central superior e foram confeccionadas seis coroas de cada sistema. A espessura das infra-estruturas utilizadas para o sistema In-Ceram foi de 0,5 $\mathrm{mm}$ na área vestibular e de 0,6 mm na área palatal, para o sistema IPS Empress de 0,6 mm na área vestibular de 0,7 $\mathrm{mm}$ na área palatina, e para o sistema metalocerâmico 0,4 $\mathrm{mm}$ na área vestibular e de 0,5 $\mathrm{mm}$ na área palatina. Os corpos de prova foram cimentados com fosfato de zinco no troquel e depois de 30 minutos foram submetidas à pressão com o auxílio de uma máquina de testes universal a uma velocidade de $0,5 \mathrm{~mm} / \mathrm{min}$ até ocorrer a fratura da porcelana. Os resultados encontrados foram de 98,3 kgf para as coroas do sistema In-Ceram, 83 kgf para as coroas do sistema IPS Empress e de 152,3 kgf para as coroas metalocerâmicas. O autor concluiu que os sistemas ceramocerâmicos mostraram valores aparentemente resistentes o suficiente para a avaliação clínica destes sistemas.

Em 1993, GREY; PIDDOCK; WILSON ${ }^{23}$ avaliaram in vitro a força requerida para fraturar coroas puras de cerâmica aluminizada (Vita $\mathrm{N}$ core), metalocerâmicas e In-Ceram Alumina. Para tanto, as coroas foram cimentadas com fosfato de zinco no troquel de latão que lhes deram origem. A resistência à fratura dos corpos de prova foi testada aplicando uma força a uma velocidade de $0,5 \mathrm{~mm} / \mathrm{min}$ dirigida ao centro das coroas. O resultado para as coroas de cerâmica pura aluminizada foi de 93,4 kgf, enquanto para as coroas In-Ceram Alumina foi de 164 kgf e para as coroas metalocerâmicas foi de 158,7 kgf. Os resultados deste teste in vitro mostraram que as coroas do sistema In-Ceram têm resistência similar às coroas metalocerâmicas.

ANDERSSON; ODEN² ${ }^{2}$ 1993, descreveram a obtenção de uma porcelana de alumina densamente sinterizada e com alta pureza (Procera AllCeram) capaz de produzir infra-estruturas cerâmicas pelo sistema CAD/CAM. Este sistema representava uma modificação no processo já 
existente de confecção de infra-estruturas metálicas. A descrição traz dados técnicos sobre a forma de preparo do dente, o sistema de obtenção da imagem do preparo assistido pelo computador e a confecção das coroas. Os autores também apresentaram resultados de pesquisas envolvendo resistência, estabilidade de cor, desgaste, precisão de ajuste, cimentação e biocompatibilidade do sistema Procera AllCeram.

Também em 1993, PRÖBSTER ${ }^{71}$, avaliou o comportamento clínico de 76 coroas de In-Ceram (61 coroas totais e 15 próteses fixas) durante cerca de 35 meses. Sessenta e uma delas eram coroas unitárias e 15 eram coroas integrantes de próteses parciais fixas. Os critérios avaliados foram: presença de trincas nas coroas, fratura da porcelana de recobrimento, fratura da infraestrutura e incidência de cárie. Durante o período de acompanhamento, uma prótese parcial fixa apresentou-se fraturada, outra foi removida por comprometimento periodontal dos pilares e uma coroa unitária apresentou incidência de lesão de cárie. Para o autor, as coroas In-Ceram podem ser consideradas adequadas para dentes anteriores e posteriores.

DONOVAN; WINSTON; CHEE $^{17}$, 1993, descreveram as características das restaurações metálicas de ouro e ceramocerâmicas, mostrando a importância de prover suporte adequado para a porcelana, assim como, uma espessura uniforme de $1,5 \mathrm{~mm}$ a 2,0 $\mathrm{mm}$ da porcelana, para evitar as falhas produzidas pela propagação das fendas de Griffith. Os autores explicaram que essas características são necessárias devido a baixa resistência da porcelana às forças de tensão.

Ainda em 1993, MUIA ${ }^{57}$ descreveu a importância do desenho da infra-estrutura para o sucesso das restaurações metalocerâmicas. O autor colocou os seguintes princípios: (1) a infra-estrutura metálica deve ser desenhada para oferecer suporte adequado à porcelana de cobertura e também deve oferecer resistência suficiente, já que as forças oclusais devem ser absorvidas pela infra-estrutura metálica da restauração; (2) se o desenho da infra-estrutura não oferece suporte conveniente à porcelana, as características de espessura, resistência e propriedades físicas do material da infra-estrutura pouco atuam no desempenho clínico das restaurações.

Em 1994, CASTELLANI et al. ${ }^{10}$ avaliaram in vitro a resistência à fratura de três sistemas de coroas ceramocerâmicas: Dicor, Hi-Ceram e coroas 
In-Ceram Alumina, comparando-as com a das coroas metalocerâmicas. Foram fabricados sete corpos de prova de cada sistema. As coroas foram colocadas no troquel metálico com características de um preparo de um pré-molar que Ihes deu origem e, em seguida, foram submetidas à pressão com o auxílio de uma máquina de testes universal Instron a uma velocidade de $1,0 \mathrm{~mm} / \mathrm{min}$. A força foi dirigida às áreas oclusal e axial dos corpos de prova. Os resultados foram: $17,048 \mathrm{~kg}$ para as coroas metalocerâmicas; 8,445 kg para as coroas HiCeram; 5,155 kg para as coroas Dicor; e 22,370 kg para as coroas In-Ceram Alumina. O sistema In-Ceram Alumina apresentou valores mais altos de resistência à fratura que os outros sistemas de coroas ceramocerâmicas, mas não apresentou diferença estatisticamente significante com as coroas metalocerâmicas. As coroas ceramocerâmicas tiveram uma fratura catastrófica independentemente dos valores de carga. As coroas metalocerâmicas apresentaram somente fraturas múltiplas da porcelana de cobertura.

Ainda em 1994, YOSHINARI; DÉRAND ${ }^{108}$ avaliaram in vitro a resistência à fratura de quatro sistemas de coroas ceramocerâmicas (Vita-Dur, In-Ceram, Dicor e IPS Empress) depois de aplicar carga cíclica nos corpos de prova numa atmosfera aquosa. Foram fabricados troquéis com dentes de bovino com dimensões similares ao preparo de um pré-molar. Os corpos de prova foram cimentados com diferentes agentes cimentantes nos troquéis e, a seguir, submetidos à pressão com o auxílio de uma máquina de testes universal, a uma velocidade de 0,225 mm/min. A força foi aplicada por meio de uma ponta esférica de 4,8 mm de diâmetro no meio da área oclusal, até ocorrer a fratura das coroas. Os resultados encontrados foram: 78,5 kgf para Vita-Dur, 108 kgf para In-Ceram, 85,6 kgf para Dicor e 90,8 kgf para IPS Empress. Os autores concluíram que a resistência das coroas convencionais de porcelana Vita-Dur diminuiu significativamente depois de ser sujeita a carga cíclica. As coroas Vita-Dur cimentadas com fosfato de zinco foram menos resistentes que as coroas cimentadas com cimentos poliquenólicos e resinosos.

CHICHE; PINAULT ${ }^{11}$, em 1994, descreveram as vantagens do sistema In-Ceram, tais como, maior resistência, excelente adaptação marginal e indicação para próteses fixas. Como desvantagens, citaram a necessidade de equipamento especial, alto custo, longo tempo para a confecção da prótese 
e necessidade de desgaste adequado do dente para mascarar a infra-estrutura de alumina.

Em 1995, SEGHI; SORENSEN ${ }^{83}$ avaliaram, in vitro, a resistência à flexão de seis cerâmicas: In-Ceram Zircônia, In-Ceram Alumina, In-Ceram Spinel, Dicor MGC, IPS Empress e Mark II (reforçada por sanidina). As cerâmicas Vita MK 68 e Soda lime-glass foram utilizadas como controle. Os corpos de prova foram confeccionados com dimensões finais de aproximadamente $5,0 \mathrm{~mm} \times 1,0 \mathrm{~mm} \times 20,00 \mathrm{~mm}$, seguindo-se as recomendações dos fabricantes de cada material. Utilizou-se o teste de carga de três pontos, com uma distância de 12,00 mm entre os apoios. Os resultados obtidos foram de 92,24 $\pm 13,04 \mathrm{MPa}$ para o grupo Soda lime-glass; 70,78 $\pm 6,91$

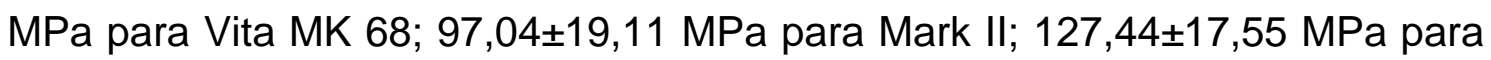
IPS Empress; 228,88 $\pm 11,30$ MPa para Dicor MGC; 377,62 $\pm 64,80$ MPa para In-

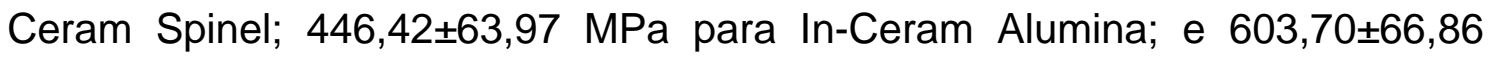
MPa para In-Ceram Zircônia. Os autores concluíram que os corpos de prova fabricados com In-Ceram Zircônia foram os mais resistentes à fratura, assim como, todas as novas cerâmicas apresentaram significativamente níveis maiores de resistência que o grupo controle de porcelana feldspática Vita MK 68.

Em 1996, ZENG; ODÉN; ROWCLIFFE ${ }^{109}$ compararam, in vitro, as falhas produzidas por estresse no sistema Procera AllCeram com três diferentes metodologias: (1) teste de carga de três pontos; (2) anel em anel; e (3) pistão em três esferas. No mesmo estudo foram utilizados os testes de anel em anel e pistão em três esferas nos sistemas de In-Ceram e IPS Empress como grupos de comparação. Os resultados dos testes foram substancialmente diferentes não sendo possível comparar diretamente os grupos. Os corpos de prova do sistema Procera AllCeram mostraram os valores de maior resistência à fratura por estresse, comparado com os outros dois grupos, obtendo valores de 601,4 MPa no teste de carga de três pontos, 469 MPa no teste de anel em anel e $640 \mathrm{MPa}$ no teste de pistão em três esferas.

WAGNER; $\mathrm{CHU}^{101}, 1996$, avaliaram a resistência flexional biaxial e dureza à fratura por endentação das cerâmicas In-Ceram, Procera AllCeram e Empress. Foram confeccionados 10 discos, medindo 16,0 mm de diâmetro por 2,0 $\mathrm{mm}$ de espessura para cada porcelana testada, de acordo com as 


\section{2 - REVISÃO DE LITERATURA}

Um fator de importância para o sucesso do desenvolvimento de restaurações em odontologia foi satisfazer as necessidades biomecânicas da cavidade oral, utilizando desenhos adequados dos materiais usados na construção destas. Em 1948, SMYD ${ }^{89}$ descreveu que todos os corpos apresentam deformação quando uma força é aplicada neles e não tem importância a intensidade da força, pois sempre existirá uma deformação. As forças de mastigação produzem deformação de compressão, tração, cisalhamento, dobramento, elongação e torção de alta magnitude na mucosa de revestimento, nos dentes e nas restaurações.

Em 1952, SMYD ${ }^{88}$ fez uma revisão de literatura, descrevendo que as forças de torque e dobramento são as responsáveis pelos fracassos das restaurações e, para prevenir as falhas dessa origem, deve ser feito um bom planejamento no desenho estrutural da restauração.

Também em 1952, SCHOLES ${ }^{80}$ em sua revisão de literatura relatou que materiais cerâmicos com boas propriedades mecânicas de resistência e dureza são usualmente cristalinos em estrutura e opacos à passagem da luz. 0 autor descreveu que dois fatores têm que ser considerados nos testes de produtos vítreos: os vidros falham sob tração e a superfície deles é o fator mais importante na sua resistência. Todas as trincas no vidro se iniciam de tensões produzidas por forças de compressão, tração, abrasão e cisalhamento. A origem destas tensões está na superfície e nos defeitos internos, tais como bolhas.

Em 1960, SILVER; KLEIN; HOWARD ${ }^{87}$ avaliaram e compararam in vitro as técnicas de fusão metal-porcelana. Os testes realizados foram a avaliação da união metal-porcelana e a resistência ao impacto da porcelana com infra-estrutura metálica. Para o teste de resistência ao impacto utilizaram o modelo falling ball test, tendo sido comparados os seguintes grupos: (1) 10\% irídio e paládio e porcelana Apco a 1.875º; (2) liga Permium 27 com porcelana Permadent a $2.100^{\circ} \mathrm{F}$; (3) liga Permium 22 com porcelana Permadent a $2.100^{\circ} \mathrm{F}$; (4) liga Micro-Bond e porcelana Micro-Bond regular; (5) liga MicroBond e porcelana Vacuum Micro-Bond; e (6) Ceramco Gold melhorado e 
recomendações de cada fabricante. Os discos foram suportados por três esferas com 3,2 mm de diâmetro posicionadas na parte inferior do disco. Em seguida, foram submetidos à pressão com auxílio de uma máquina de testes universal a uma velocidade de 1,0 mm/min; A dureza a força foi aplicada no centro do disco por meio um bastão de aço de 1,4 mm de diâmetro. Os resultados obtidos para à resistência flexional biaxial mostraram diferença estatisticamente significante sendo o IPS Empress apresentou os menores valores (134 MPa); o Procera AllCeram os maiores (687 MPa); e In-Ceram intermediários (352 MPa).

Também em 1996, PRÖBSTER ${ }^{72}$ conduziu um estudo clínico longitudinal de 95 coroas do sistema In-Ceram Alumina, por 56 meses. As coroas foram construídas a partir de preparos dentais em 18 pacientes e cimentadas com cimento de fosfato de zinco (dentes posteriores) e com cimento de ionômero de vidro (dentes anteriores). Os pacientes eram chamados para exame clínico ao menos uma vez ao ano e os critérios avaliados no exame foram: presença de trincas nas coroas, fratura da porcelana de recobrimento, fratura da infra-estrutura, infiltração nas margens, cáries e desgaste oclusal ou abrasão. A cobertura de uma coroa posterior apresentou fratura e quatro coroas apresentaram cárie em suas margens. As demais restaurações não apresentaram qualquer sinal, dentre os requisitos acima descritos, fazendo com que os autores concluíssem que o sistema InCeram Alumina estaria indicado para dentes anteriores e posteriores.

Em 1997, GARDNER et al. ${ }^{21}$ compararam a resistência à fratura de coroas metalocerâmicas fabricadas tradicionalmente com dois tipos de margem diferente (cintas faciais de metal e cintas faciais de porcelana), sobre um preparo de um canino fabricado com resina. As coroas foram jateadas com óxido de alumínio de $50 \mu \mathrm{m}$ e cimentadas no troquel de resina com cimento de ionômero de vidro híbrido. Depois de 24 horas foram submetidas à pressão sobre o ângulo da línea incisivo-lingual com auxílio de uma máquina de teste universal Instron a uma velocidade de $2,5 \mathrm{~mm} / \mathrm{min}$. Os resultados obtidos para as coroas com margem de porcelana foram de 192,7 kgf e para as coroas com margem metálica de 137,6 kgf. Os autores concluíram que a força requerida para fraturar as coroas metalocerâmicas com margem de porcelana foi maior e 
estatisticamente significante, quando comparado com as coroas com cinta marginal metálica.

O'BOYLE et al. ${ }^{63}, 1997$, avaliaram a resistência à fratura de coroas metalocerâmicas com um novo desenho de infra-estrutura. Foram fabricados vinte corpos de prova com vários graus de redução no metal da área vestibular marginal $(0,1,2$ e $3 \mathrm{~mm})$. As coroas foram cimentadas com um cimento resinoso dual no troquel metálico com características de um preparo de um incisivo central. Em seguida, as coroas foram submetidas à pressão com 0 auxílio de uma máquina de testes universal Instron a uma velocidade de 1,0 $\mathrm{mm} / \mathrm{min}$. A força foi aplicada nas bordas incisais, no longo eixo da coroa, por meio de uma ponta plana de aço de $3,6 \mathrm{~cm}$. Os resultados mostraram que o grupo controle ( $0 \mathrm{~mm}$ de redução) e o grupo com $1 \mathrm{~mm}$ de redução não apresentam diferença estatisticamente significante. A resistência à fratura das infra-estruturas com redução foi diminuindo ao mesmo tempo em que aumentava a redução da infra-estrutura.

RAMOS JUNIOR; BATISTA; MIRANDA ${ }^{76}, 1997$, descreveram os princípios para a confecção da infra-estrutura de restaurações metalocerâmicas: rigidez, controle das forças de tensão e compressão, condições de estética, biocompatibilidade da vitalidade do periodonto e dente, coeficiente de expansão térmica, espaço para espessura correta da porcelana, estrutura com superfície arredondada, dentes antagonistas não contatar na junção metal/porcelana e condições para higienização. Os autores também ressaltaram alguns conceitos básicos para as restaurações unitárias: (1) reforço de cinta em toda a borda da restauração, além de reforçar as margens do padrão de cera; (2) ombro lingual reforçado, pois a infra-estrutura requer mais rigidez que o provido pelo reforço da cinta; e (3) resistência à tração, ou seja, o desenho deverá ser de tal forma a dar suporte à porcelana, transformando as forças de tração em compressão, o que é bem tolerado pela porcelana, evitando então as fraturas.

MCLEAN $^{45}$, em 1998, chamou a atenção para o fato de que as infraestruturas das coroas ceramocerâmicas, como as feitas de alumina, deveriam apresentar as mesmas características das infra-estruturas das coroas metalocerâmicas, visando obter a resistência necessária para suportar os esforços mastigatórios. 
Em 1998, STRUB; BESCHINDT ${ }^{94}$ avaliaram, in vitro, a resistência à fratura de cinco sistemas para coroas ceramocerâmicas (In-Ceram, Empress 1, Empress 2, Celay sistema feldspático e Celay sistema In-Ceram), antes e depois de serem submetidos à carga cíclica numa boca artificial. Os autores utilizaram as coroas metalocerâmicas fabricadas com uma liga ouro-platina como grupo controle. Sessenta incisivos superiores foram extraídos e incluídos em blocos de resina e as coroas foram cimentadas aos dentes preparados utilizando um cimento resinoso. Metade dos corpos de prova (cinco coroas de cada grupo) foi colocada em um simulador artificial de movimentos mastigatórios (1,2 milhões de ciclos) e também submetida a 3.000 ciclos de termociclagem. Em seguida, todos os corpos de prova foram submetidos à pressão com auxílio de uma máquina de testes universal a uma velocidade de $2 \mathrm{~mm} / \mathrm{min}$. A força foi dirigida na borda incisal dos corpos de prova com uma inclinação de 30 graus em relação ao longo eixo do dente. Para a distribuição da força foi utilizada uma lâmina de estanho de $0,8 \mathrm{~mm}$ de espessura localizada entre a borda incisal da coroa e o ponto de aplicação da força. Os resultados obtidos para os corpos de prova submetidos aos movimentos de mastigação e termociclagem previamente ao teste de compressão foram significantemente menores, quando comparados com os demais corpos de prova. Não se verificou diferença estatística significante entre os grupos de coroas ceramocerâmicas e o grupo de coroas metalocerâmicas. Os autores concluíram que as coroas ceramocerâmicas podem ser utilizadas para restaurações na região anterior.

ODÉN et al. ${ }^{64}, 1998$, num estudo clínico, registraram um índice de fratura de 5,2\% para próteses unitárias de Procera AllCeram após 5 anos. Das 97 próteses unitárias que foram colocadas, 3,1\% fraturaram o núcleo cerâmico e a cerâmica de cobertura e 2,1\% fraturaram apenas a cerâmica de cobertura.

Ainda em 1998, NEIVA et al. ${ }^{62}$ compararam a resistência à fratura e a espessura da linha de cimento de três sistemas cerâmicos: IPS Empress, InCeram e Procera AllCeram. Para determinar a resistência à fratura, utilizaram 30 troquéis de resina com módulo de elasticidade semelhante ao da dentina, obtidos a partir de um troquel-padrão. Foram confeccionadas dez coroas para cada sistema, que foram cimentadas sobre seus respectivos troquéis com cimento resinoso Panavia 21. Após a cimentação, as próteses foram 
armazenadas em ambiente com 100\% de umidade, por 24 horas. Em seguida, foram submetidas à pressão axial sobre a superfície oclusal, com o auxílio de uma máquina de testes universal Instron a uma velocidade de 0,05 $\mathrm{mm} / \mathrm{min}$. A força foi aplicada no centro da face oclusal por meio de uma esfera de aço de 4,0 mm de diâmetro. O sistema IPS Empress apresentou a maior média de resistência à fratura $(222,45 \mathrm{~kg})$, enquanto o sistema Procera AllCeram, a menor $(194,20 \mathrm{~kg})$. O sistema In-Ceram apresentou um valor intermediária: $(218,80 \mathrm{~kg})$.

McLAREN; WHITE ${ }^{44}$, em 2000, realizaram um estudo prospectivo para avaliar a longevidade de coroas In-Ceram confeccionadas em clínica particular, desde a introdução do sistema em 1990 até 1997. Foram avaliadas 408 coroas confeccionadas por um único protético em 107 pacientes, no período de 1 a 86 meses. As coroas foram fabricadas seguindo as recomendações do fabricante. Vários tipos de cimentos foram utilizados para cimentação das coroas incluindo resinosos, ionômero de vidro modificado por resina, ionômero de vidro convencional, policarboxilato e fosfato de zinco. Depois de completar o tratamento, os pacientes foram chamados a cada seis meses para avaliação. Os autores encontraram baixa porcentagem de falhas, aproximadamente 1,35\% por ano, e que estavam associadas a fraturas da infra-estrutura $(0,6 \%)$, da porcelana $(0,3 \%)$ e descimentação $(0,3 \%)$. As falhas em pré-molares foram mais comuns que nos dentes anteriores, não havendo, porém, diferença estatisticamente significante entre dados.

GIORDANO $\|^{22}$, em 2000, descreveu alguns sistemas cerâmicos para confecção de coroas totais, destacando as propriedades físicas do sistema In-Ceram. Segundo o autor, as infra-estruturas fabricadas com alumina apresentavam resistência flexural entre $450 \mathrm{MPa}$ e $600 \mathrm{MPa}$, sendo indicadas em elementos isolados anteriores e posteriores e próteses parciais fixas anteriores de três elementos. O sistema In-Ceram Spinell diferiu do primeiro pela alta transluscência e menor resistência flexural (350 MPa), sendo indicado para inlays e onlays. O sistema, In-Ceram Zircônia apresento resistência flexural acima de 750 MPa e, devido a sua baixa translucidez, estaria indicado para coroas em dentes posteriores.

SEGAL ${ }^{81}, 2001$, estudou a longevidade de 546 coroas In-Ceram na região anterior $(32,4 \%, n=177)$ e posterior $(67,6 \%, n=369)$ da boca, em um 
período de seis anos. Todas as coroas foram preparadas, cimentadas e periodicamente avaliadas pelo mesmo clínico. As coroas foram fabricadas por diferentes laboratórios e técnicos dentais e cimentadas com ionômero de vidro modificado por resina. Depois de cimentadas todas as coroas foram mantidas em observação a cada seis meses. Os resultados obtidos foram: $0,9 \%$ das coroas falharam por fracasso na infra-estrutura e 0,5\% falharam por fratura da porcelana. O insucesso das coroas na região anterior foi de 1,1\%, e nas coroas da região posterior foi de $0,8 \%$. O autor concluiu que as coroas In-Ceram são duráveis e provêem ótima estética nas áreas anterior e posterior da boca, sempre que seja respeitado o protocolo de preparo e cimentação.

Em 2001, VAN DER ZEL et al. ${ }^{98}$ descreveram um método de fabricação de coroas chamado CICERO, o qual consiste na digitalização óptica do troquel de gesso e desenho da coroa. O material da infra-estrutura deve ser prensado e sinterizado com camadas consecutivas de alumina altamente resistente. Posteriormente é colocada uma camada de porcelana de dentina, e uma camada final de porcelana incisal. Os autores descreveram que o desenho da infra-estrutura deveria ser de uma espessura de 0,7 a 0,8 $\mathrm{mm}$, mas também poderia ser ajustado ás necessidades da restauração. Os autores definiriam o método CICERO como uma forma eficiente de fabricar restaurações ceramocerâmicas sem comprometer a estética e a função.

McLEAN $^{46}$, 2001, realizou uma revisão da evolução das porcelanas dentais no século $X X$, descrevendo o desenvolvimento dos vários tipos de porcelanas disponíveis no mercado. O grande marco da estética na prótese começou com a possibilidade da união da porcelana com o metal, para o desenvolvimento da técnica metalocerâmica. Segundo o autor, a partir de 1970, o aparecimento das porcelanas reforçadas por cristais de alumina possibilitou que estes materiais apresentassem o dobro de resistência (180 MPa) quando comparadas, ás porcelanas convencionais, e foi possível confeccionar coroas collarless. Também afirmou que as cerâmicas vítreas apareceram a partir de 1968 com ADAIR e GROSSMAN ${ }^{1}$ em 1973, surgiu o sistema Dicor (Dentsply). As porcelanas com alta concentração de alumina geralmente contém 95\% de óxido de alumina e apresentam alta resistência, (acima de $800 \mathrm{MPa}$ ) possibilitando a confecção de uma infra-estrutura que após infiltrada com vidro pode receber a aplicação de porcelana de 
revestimento para prover a estética necessária. Estão indicadas para confecção de coroas e próteses fixas de três elementos. A técnica de slipcasting foi refinada e usada por SADOUN ${ }^{79}$, em 1989, o que permitiu a utilização de porcelana aluminizada na confecção de infra-estruturas para coroas e prótese fixa sem comprometer a resistência, sendo comercializada com o nome de In-Ceram. Na técnica utiliza-se um pó de alumina sinterizada que recebe a injeção de vidro de baixa fusão de lantânio de sódio para produzir uma cerâmica composta de alta resistência (em torno de $630 \mathrm{Mpa}$ ) contendo uma concentração de alumina é de 72\%. O autor destacou a grande importância do trabalho do SADOUN ${ }^{79}$. Em 1993, ANDERSSON; ODEN ${ }^{2}$ desenvolveram um sistema conhecido comercialmente como Procera AllCeram, que utiliza porcelana com alta concentração de alumina $(99,9 \%)$ de grande pureza e que apresenta alta resistência, possibilitando a substituição das infra-estruturas metálicas nas coroas. As infra-estruturas são confeccionadas através da compactação de pó de alumina através de uma técnica de pressurização a seco. McLEAN ${ }^{46}, 2001$, conclui que no século 210 desafio de produzir coroas ceramocerâmicas com alta resistência sem sacrificar a translucidez pode ser atingido, mas as restaurações metalocerâmicas ainda serão utilizadas por muito tempo.

Em 2000, BOTTINO ${ }^{8}$ descreveu que o sistema In-Ceram Alumina possui grande quantidade de partículas de alumina com diâmetro entre 0,5 e 3,5 $\mu \mathrm{m}$ e por isso apresenta uma contração de sinterização de $0,3 \%$, possibilitando uma microestrutura organizada. Considerou que o tamanho das partículas, o baixo índice de contração e a facilidade da técnica permitem a obtenção de uma fidelidade marginal. O sistema In-Ceram Alumina por apresentar uma resistência flexional entre 300 e 600 MPa é indicado para confecção de próteses tanto na região anterior como na posterior. A infraestrutura deste sistema é obtida através da mistura de óxido de zircônia e óxido de alumina (67\%), o que aumenta a resistência flexural e a resistência do material à propagação de trincas.

SGRÒ ${ }^{84}$, 2002, baseado numa revisão cuidadosa das técnicas existentes, e em estudos de física, arquitetura e estudos de engenharia mecânica e arquitetural, propôs modificações do desenho da infra-estrutura para restaurações metalocerâmicas. Aplicou o principio de franzimento, ou 
seja, o método de concreto reforçado, e o principio de estresse compressivo do cimento para próteses ceramocerâmicas unitárias ou múltiplas. Assim, tanto os elementos metálicos como os cerâmicos afetam diretamente a resistência e rigidez da prótese, desde que a infra-estrutura forneça alta resistência à tensão, e a cerâmica forneça alta resistência à compressão. As modificações resultaram numa nova configuração geométrica da infra-estrutura, que garantiu uma restauração com maior e melhor desempenho clínico. Neste sistema stressbreakers, relacionados ao volume de cerâmica a ser suportada, divide a cerâmica e gera vários centros de contração que possibilitam controlar a contração da porcelana. Tanto na infra-estrutura metálica como na porcelana de revestimento existem linhas paralelas de estresse convergindo para certos centros de contração. Assim a cerâmica gera uma tensão radial na infraestrutura metálica, a qual coloca por sua vez a cerâmica em compressão circular. A compressão ocorre tanto na cerâmica como na interface metalocerâmica. Consequentemente, uma união mais resistente é produzida entre os dois materiais produzindo um sistema restaurador mais resistente. Esta proposta é muito diferente das apontadas para as infra-estruturas tradicionais, em que a maioria da resistência e rigidez é derivada da espessura da infraestrutura metálica suportando uma capa fina e superficial de cerâmica.

Também em 2002, ROSENSTIEL; LAND; FUJIMOTO ${ }^{78}$ descreveram o desenho da infra-estrutura para restaurações metalocerâmicas baseados no princípio de que as porcelanas odontológicas (que são, do ponto de vista químico, similares aos vidros) resistem à carga compressiva, mas tendem a sucumbir ao esforço de tensão. Portanto, as infra-estruturas devem ser projetadas de forma que qualquer esforço de tensão na porcelana seja minimizado. Propôs que a espessura da porcelana não deve exceder $2 \mathrm{~mm}$, para evitar a fratura e que para uma restauração esteticamente satisfatória a espessura mínima devia ser de $1 \mathrm{~mm}$. O desenho da infra-estrutura de uma prótese deve ser considerado durante o plano de tratamento e avaliado no preparo diagnóstico do dente no estágio do enceramento da restauração, já que o principal objetivo do enceramento é a formação de uma infra-estrutura que permita uma espessura de porcelana uniforme. Os autores concluíram que o desenho da infra-estrutura das restaurações metalocerâmicas deve ser baseado em uma compreensão das propriedades fundamentais do material. As 
restaurações devem ser enceradas até o contorno anatômico e depois reduzidas na área na qual a porcelana será aplicada, assim este procedimento cria uma espessura uniforme da porcelana, que promove propriedades mecânicas superiores nas restaurações, ao mesmo tempo em que padroniza a reprodução da tonalidade.

KU; PARK; YANG ${ }^{37}, 2002$, avaliaram a resistência à fratura três tipos de coroas de cerômeros (Artglass, Sculpture e Targis). Para determinar a resistência à fratura, utilizaram 10 troquéis de resina níquel-cromo obtidos a partir de um troquel-padrão de resina com forma similar ao um preparo de um incisivo. Foram fabricados 10 corpos de prova de cada grupo, que foram cimentadas sobre seus respectivos troquéis com cimento de ionômero de vidro híbrido. Em seguida, as coroas foram submetidas à pressão sobre a linha do ângulo inciso-lingual, com uma inclinação de 130 graus ao longo do eixo destas. Usou-se uma máquina de testes universal Instron a uma velocidade de $1 \mathrm{~mm} / \mathrm{min}$ até ocorrer à fratura catastrófica das coroas. Para aplicar a força foi utilizada uma barra de $7 \mathrm{~mm}$ de diâmetro. As coroas metalocerâmicas apresentaram a maior média de resistência à fratura (134,4 kgf), seguidas dos sistemas Sculpture (63,3 kgf), Targis (61,3 kgf) e Artglass (58,6 kgf). Os sistemas de cerâmica pura apresentaram valores menores de resistência à fratura quando comparados com as coroas metalocerâmicas, contudo excediam os valores normais das forças mastigatórias.

Também em 2002, FRADEANI; REDEMAGNI ${ }^{20}$ avaliaram o desempenho clínico de 125 coroas ceramocerâmicas do sistema IPS Empress num período de 4 a 11 anos. As coroas (93 coroas anteriores e 32 posteriores) foram cimentadas em 54 pacientes por dois clínicos distintos. Foram avaliadas clinicamente por radiografias e fotografias clínicas de acordo com o sistema de avaliação da Associação Dental da Califórnia. Os resultados para as 125 coroas foram: 95,2\% de êxito e 4,8\% de fracasso; das restaurações que fracassaram uma foi da região anterior e cinco foram da região posterior.

Ainda em 2002, ULUSOY; TOKSAVUL ${ }^{97}$ avaliaram a resistência à fratura de cinco desenhos diferentes de infra-estrutura para coroas metalocerâmicas. Para determinar a resistência à fratura foi elaborado um troquel-metálico a partir do um preparo de um incisivo central extraído. Foram fabricadas 25 coroas com diferentes níveis de redução na cinta metálica 
vestibular: grupo (1) cinta metálica estendida até a margem vestibular do preparo; grupo (2) margem metálica reduzida até a linha do ângulo axiogengival; grupo (3) margem metálica reduzida até $1 \mathrm{~mm}$ antes da linha do ângulo axiogengival; grupo (4) margem metálica reduzida até 0,5 mm antes da linha do ângulo axiogengival; e grupo (5) margem metálica reduzida até 1,5 mm antes da linha do ângulo axiogengival. Os corpos de prova foram submetidos à termociclagem e, em seguida submetidos à pressão axial com auxílio de uma máquina de testes universal Shimadzu a uma velocidade de $1 \mathrm{~mm} / \mathrm{min}$, até ocorrer a fratura deles. A força foi dirigida na borda incisal dos corpos de prova, paralela ao longo eixo, com a ajuda de uma ponta plana de aço de $15 \mathrm{~mm}$ de diâmetro. As coroas metalocerâmicas com cinta metálica apresentaram maiores valores de resistência à fratura que os grupos com redução da margem metálica. Assim, à medida que a redução da margem metálica aumentava, a resistência à fratura diminuía.

Em 2004, POLIKET; CHICHE; FINGER ${ }^{68}$ avaliaram e compararam a resistência à fratura em três tipos diferentes de coroas fabricadas com 2 sistemas cerâmicos variando a espessura da infra-estrutura e coroas metalocerâmicas. Para determinar a resistência à fratura foram utilizados 40 incisivos centrais superiores humanos e divididos em quatro grupos: (1) MMC de coroas metalocerâmicas (grupo controle); grupo (2) AC4 de coroas com 0,4 $\mathrm{mm}$ de espessura na infra-estrutura de óxido de alumínio (Procera AllCeram); grupo (3) AC6 de coroas com 0,6 mm de espessura na infra-estrutura de óxido de alumínio (Procera Allceram); e grupo (4) ZC6 de coroas com 0,6 mm de espessura na infra-estrutura de óxido de zircônia (Procera AllZircon). As coroas foram cimentadas nos dentes preparados com cimento resinoso Panavia 21 e, em seguida foram testadas a resistência à fratura com auxílio de uma máquina de testes universal, a uma velocidade de $2 \mathrm{~mm} / \mathrm{min}$. A força foi dirigida à borda incisal das coroas com um ângulo de 30 graus em relação ao longo eixo do dente. Os resultados obtidos foram de 41,3 kgf para o grupo MMC; 45,5 kgf para o grupo AC4; 48,5 kgf para o grupo AC6; e 38,8 kgf para o grupo ZC6. Os autores não encontraram diferença estatisticamente significante entre os grupos testados.

PALLIS et al. ${ }^{66}, 2004$, avaliaram e compararam a resistência à fratura e a origem da fratura de coroas ceramocerâmicas na região posterior de 
três sistemas cerâmicos (IPS Empress 2, Procera AllCeram e In-Ceram Zircônia). Foram fabricadas 50 coroas de cada sistema cerâmico e cimentadas com cimento resinoso Rely $\mathrm{X}$ em troquéis de resina simulando o preparo de um primeiro molar superior. Em seguida, as coroas foram submetidas à pressão axial em sentido oclusal com auxílio de uma máquina de testes universal Instron a uma velocidade de 0,5 mm/min. A força foi aplicada com uma ponta esférica de aço de 6,35 mm de diâmetro. Os resultados obtidos de resistência à fratura foram de 78,62 a 113,70 kgf para IPS Empress 2; 87,60 a 110,75 kgf para Procera AllCeram e 101,77 a 120,64 kgf para In-Ceram Zircônia. A origem da fratura encontrada na maioria dos corpos de prova IPS Empress 2 foi localizada na interface entre a cerâmica e a infra-estrutura e para Procera AllCeram e In-Ceram Zircônia, na interface da infra-estrutura e o agente cimentante.

VITA ${ }^{100}$, em 2005, publicou um fascículo a respeito da confecção de restaurações ceramocerâmicas. Recomendou um desenho para as infraestruturas das coroas na região posterior, especificando a espessura de 0,7 $\mathrm{mm}$ para a área oclusal e de 0,5 $\mathrm{mm}$ para a área circundante.

Em 2006, MENDES et al. ${ }^{55}$ descreveram as tendências atuais da prótese fixa. Os autores relataram que os sistemas ceramocerâmicos apresentam excelentes propriedades de biocompatibilidade e estéticas, no entanto, ainda não existem dados clínicos sobre a utilização em áreas de maior carga (posteriores), porque apresentam menor resistência a esforços tensionais, quando comparados com os sistemas metalocerâmicos.

Também em 2006, BOTTINO; FARIA; BUSO ${ }^{7}$ revisaram a literatura sobre o sistema In-Ceram e descreveram que o desenho e a espessura da infra-estrutura têm um efeito fundamental na resistência e na obtenção de estética. O desenho descrito pelos autores é uma infra-estrutura uniforme adaptada à forma do preparo e com uma espessura da infra-estrutura em coroas unitárias de $0,7 \mathrm{~mm}$ na face oclusal ou incisal e $0,5 \mathrm{~mm}$ para as faces proximais e, em próteses fixas de três elementos, de $0,7 \mathrm{~mm}$ na face oclusal ou incisal e 0,7 $\mathrm{mm}$ para as faces proximais.

VEDOVATO; YASUDA ${ }^{99}, 2006$, em sua revisão de literatura sobre o sistema Procera e com base em experiência clínica, relataram que apesar de existir grande integração entre a infra-estrutura e a porcelana de recobrimento 
deste sistema, é necessária uma infra-estrutura que dê suporte à porcelana durante a função mastigatória para evitar a fratura. Desta maneira, os autores recomendaram a confecção da infra-estrutura com um suporte horizontalproximal e palatino ou lingual, similar ao desenho de infra-estrutura para coroas metalocerâmicas.

Ainda em 2006, HAGMANN; MARINELLO; ZITZMANN ${ }^{27}$ investigaram a resistência à fratura de coroas ceramocerâmicas do sistema Procera AllCeram (tecnologia CAD/CAM), comparando um desenho de infraestrutura reduzida "collarless" com o desenho de infra-estrutura convencional. Investigaram, também, a influência da forma do preparo (molares ou prémolares) e do material de cimentação (ionômero de vidro ou resinoso). Para o estudo do formato do preparo foram fabricados 120 corpos de prova, sendo 30 coroas com infra-estrutura com margem reduzida "collarless" e 30 coroas com infra-estrutura convencional (grupo controle), tanto para os molares como os pré-molares. Para o teste de agente cimentante, 40 coroas de cada grupo foram cimentadas num troquel metálico com Ketac-Cem Aplicap ou Panavia F. Os outros 40 corpos de prova foram colocados num troquel de poliuretano, sem cimento. Todos os corpos de prova foram submetidos à pressão sobre a superfície oclusal até ocorrer a fratura catastrófica. Não foi encontrada diferença estatisticamente significante na resistência à fratura das coroas em molares, nem para os diferentes desenhos da infra-estrutura ("collarless" e grupo controle) nem para o agente cimentante. Para os pré-molares, ocorreu uma redução na resistência à fratura com o desenho "collarless", enquanto o uso de cimento resinoso foi associado ao incremento da resistência. Os resultados deste estudo in vitro indicaram que para o sistema de coroas ceramocerâmicas Procera AllCeram é preferível utilizar um desenho convencional na infra-estrutura e cimento resinoso em preparos de formato arredondado, especialmente na região posterior devido ao aumento das forças mastigatórias nesta região. Estes resultados carecem ainda de estudos clínicos. 


\section{3 - PROPOSIÇÃO}




\section{3 - PROPOSIÇÃO}

O objetivo deste estudo foi avaliar a resistência à fratura por compressão axial de infra-estruturas que receberam aplicação de cerâmica de revestimento, assim constituídos:

1. Infra-estruturas metálicas para coroas metalocerâmicas e de alumina (In-Ceram Alumina) para coroas ceramocerâmicas.

2. A presença ou ausência das estruturas de reforço (cinta lingual e poste proximal) nessas infra-estruturas.

3. O tipo de fratura decorrente da força de compressão axial. 


\section{4 - MATERIAL E MÉTODOS}




\section{4 - MATERIAL E MÉTODOS}

Para a realização deste trabalho, 40 troquéis de gesso especial foram obtidos a partir de quatro troquéis-padrão fundidos em liga de níquelcromo, reproduzidos a partir de um dente natural pré-molar superior preparado para coroa total. Foram confeccionadas 20 coroas metalocerâmicas e 20 ceramocerâmicas, com diferentes desenhos na suas infra-estruturas (com e sem reforço) e submetidas à análise de resistência à fratura usando uma máquina de teste universal, a uma velocidade de 0,5 mm/min. Os corpos de prova foram mantidos sob pressão até a ocorrência da fratura. Para possibilitar o desenvolvimento dessa metodologia, utilizou-se o seguinte material:

1. Accufilm IV - Parkell Biomaterials Division - Farminglade, NY, USA.

2. Acrílico autopolimerizante - JET (pó) Clássico - São Paulo, SP.

3. Acrílico autopolimerizante - JET (liquido) Clássico - São Paulo, SP.

4. Antibolhas Excelsior - S.S. White Artigos Odontológicos - Rio de Janeiro, RJ.

5. Borrachas abrasivas - Deco Dental - São Paulo, SP.

6. Brocas esféricas $\mathrm{n}^{\circ} 2$ Carbide - S.S. White Artigos Odontológicos Rio de Janeiro, RJ.

7. Centrífuga - Stipp - Juiz de Fora, MG.

8. Cera para fundição Rainbow opaca - Ceras Rainbow Ltda - Porto Ferreira, SP.

9. Cerâmica In-Ceram Alumina - VITA - Zahnfabrik, Bad Säckingen, Suíça.

10. Cimento de ionômero de vidro modificado por resina Rely- $X^{\mathrm{TM}}$ Luting 2 - 3M ESPE - St. Paul, MN, USA.

11. Delineador - DFL - São Paulo, SP.

12. Discos de carborundum - Dentorium n 221 - Nova York, NY, USA.

13. Forno elétrico - EDG - São Carlos, SP.

14. Gesso tipo IV Durone - Dentsply Ind. e Com. Ltda. - Petrópolis, RJ.

15. Inclusor a vácuo - Whip-Mix, C.i, Model B.- Louisville, IL, USA. 
16. Isolante para troquéis Desmoldy - Ind. e Com. Produtos Odontológicos Padron Ltda. - Porto Ferreira, SP.

17. Jato de óxido de alumínio Trijato - Labor Dental - São Paulo, SP.

18. Jogo de instrumentos PKT Labordent - Labordental Ltda. - São Paulo, SP.

19. Lâmina de bisturi $n^{\circ} 15$ - Feather - Japão.

20. Liga de níquel-cromo (Ni-Cr) VeraBond II - AlbaDent - Cordelia, CA, USA.

21. Lupa com aumento de $4 \mathrm{x}$ - Lactona Corporation - USA.

22. Máquina universal de testes Kratos, modelo K-2000MP Dinamômetros Kratos Ltda.,- São Paulo, SP.

23. Moldura circular de PVC.

24. Pedras de óxido de alumínio - SHOFU Dental - Alemanha.

25. Poliéter Impregum F (base, catalisador e adesivo)- ESPE Dental Alemanha.

26. Porcelana Noritake Super Porcelain EX-3 - Noritake Co. Limited Nagoya, Japão.

27. Porcelana Noritake Cerabien - Noritake Co. Limited - Nagoya, Japão.

28. Resina acrílica Duralay - Reliance Dental Mfg Co. Worth - IL, USA.

29. Revestimento Micro Fine 1700 - Talladium, I.N.C. - Valencia, CA, USA.

30. Silicona de condensação de massa densa - Zetaplus, Zhermack SpA - Itália.

31. Sonda Exploradora no 5 EXD5 - Hu-Friedy - Chicago, IL, USA.

32. Transferidor plástico - Waleu PT - São Paulo, SP.

33. Turbina de alta rotação Kavo Roll Air - Kavo do Brasil - Joinvile, SC.

34. Vaselina sólida - Ind. Farmacêutica Rioquímica Ltda - São José do Rio Preto, SP. 


\section{1 - OBTENÇÃO DOS TROQUÉIS-PADRÃO}

Um dente pré-molar superior foi preparado para coroa total, apresentando as seguintes características:

a) Ângulo de convergência aproximadamente de $15^{\circ}$;

b) Término cervical nítido em chanfrado, com redução circunferencial de 1,3 mm, localizado próximo à união cemento-esmalte;

c) Redução oclusal de 2,0 mm;

d) Altura da face vestibular de 5,0 $\mathrm{mm}$ e da face lingual de 4,5 mm;

e) Arredondamento dos ângulos.

Para o preparo foram utilizadas pontas diamantadas esférica e cilíndrica de extremidade arredondada, além de broca multilaminada cilíndrica de extremidade arredondada.

O dente assim preparado foi duplicado, utilizando-se silicona de condensação de massa densa; o molde foi preenchido com resina acrílica Duralay. Foram obtidas quatro réplicas, uma para cada grupo experimental, as quais foram incluídas e fundidas em liga de níquel-cromo, pela técnica da cera perdida. Após o acabamento superficial com pedras de óxido de alumínio e polimento com borrachas abrasivas, os troquéis-padrão metálicos foram fixados em uma base de resina acrílica incolor. Com o auxílio de um delineador, os troquéis-padrão foram posicionados verticalmente no centro de cilindros ocos de PVC com 22 mm de diâmetro e $30 \mathrm{~mm}$ de altura. Em seguida, a moldura foi preenchida com resina acrílica incolor ativada quimicamente, mantendo o término cervical do preparo cerca de $5 \mathrm{~mm}$ distante da borda superior da base (Figura 4.1). 


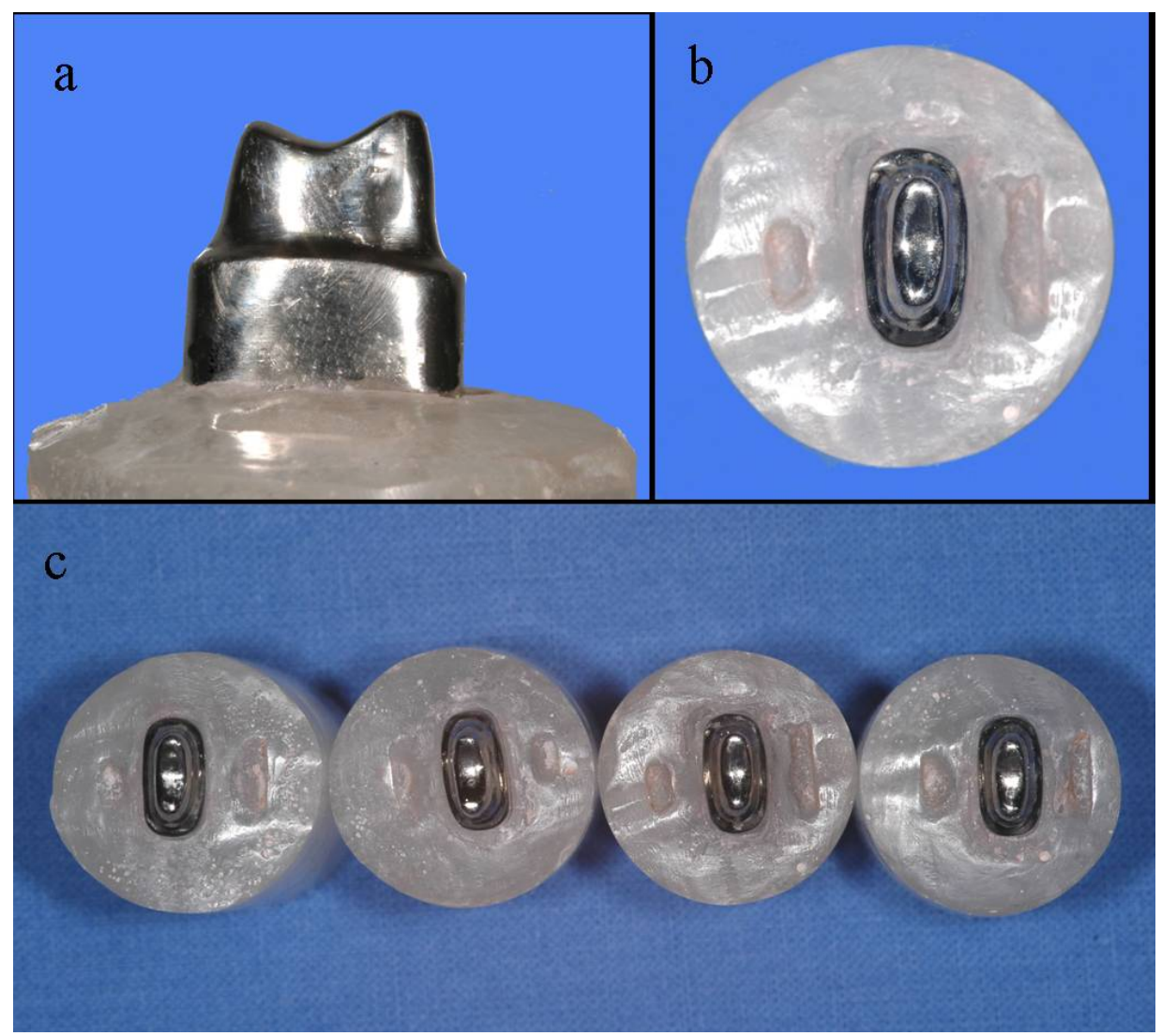

Figura 4.1 - Troquéis-padrão metálicos. Vista proximal (a) e vista oclusal (b) de um troquel; quatro troquéis, um para cada grupo experimental (c)

Os troquéis-padrão previamente preparados foram fixados a uma base de resina acrílica Duralay, com o auxílio de um delineador e um transferidor. Na sua porção inferior, essa base apresentava dois pinos que se encaixavam em dois orifícios preparados na plataforma de um paralelômetro modificado para esse experimento e que possibilitava o posicionamento dos troquéis-padrão/base de resina Duralay sempre na mesma posição (Figura 4.2). 


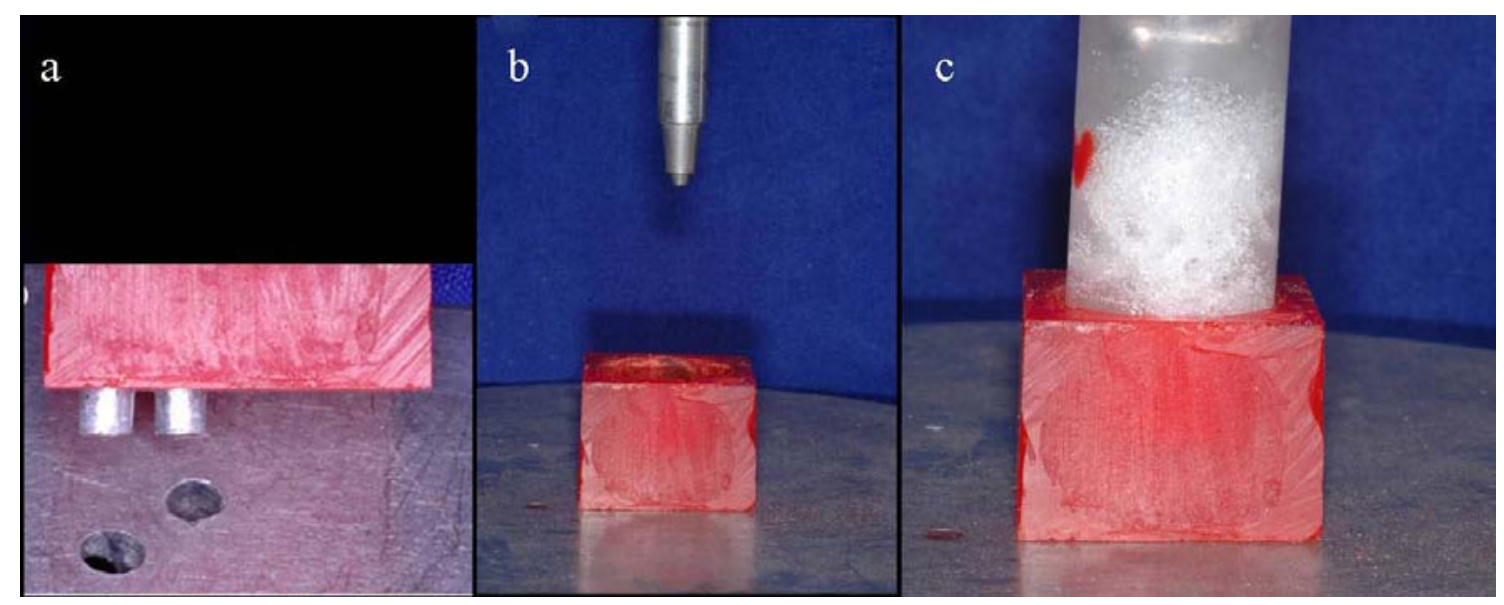

Figura 4.2 - Base da resina acrílica Duralay mostrando pinos que se encaixam nos orifícios na plataforma do paralelômetro modificado (a); base de resina acrílica Duralay fixada na plataforma do paralelômetro (b); e base e troquel-padrão fixados à base de resina Duralay (c)

\section{2 - OBTENÇÃO DOS TROQUÉIS DE GESSO}

A haste vertical do paralelômetro também foi modificada de tal forma que possibilitasse carga estática uniforme durante a tomada do molde.

$\mathrm{Na}$ extremidade inferior da haste vertical posicionou-se um mandril de peça de mão, o qual mantinha contato com as moldeiras individuais de resina acrílica Duralay e que possibilitou a uniformidade de espessura do material de moldagem. As moldeiras, que se encaixavam na base de resina acrílica incolor, foram confeccionadas com alívio interno de 0,5 mm, em relação à superfície externa dos troquéis-padrão.

$\mathrm{Na}$ extremidade superior da haste vertical confeccionou-se e fixou-se por meio de rosqueamento um dispositivo para a determinação da carga estática, que era constituído de aço inoxidável, de tal forma que o conjunto (dispositivo para carga, haste vertical e mandril) perfizesse 2 kg (Figura $4.3 \mathrm{a}$ ).

O material de moldagem utilizado foi o poliéter Impregum $F$, manipulado em porções iguais de acordo com as instruções do fabricante. As moldeiras individuais foram antecipadamente pinceladas com uma camada de adesivo próprio, que foi seco com jatos de ar. O material espatulado foi levado ao interior das moldeiras individuais. Realizou-se o assentamento sobre os troquéis-padrão por meio de pressão digital e, em seguida, a carga estática foi mantida pelos dispositivos fixados na haste vertical (Figura 4.3 b) 


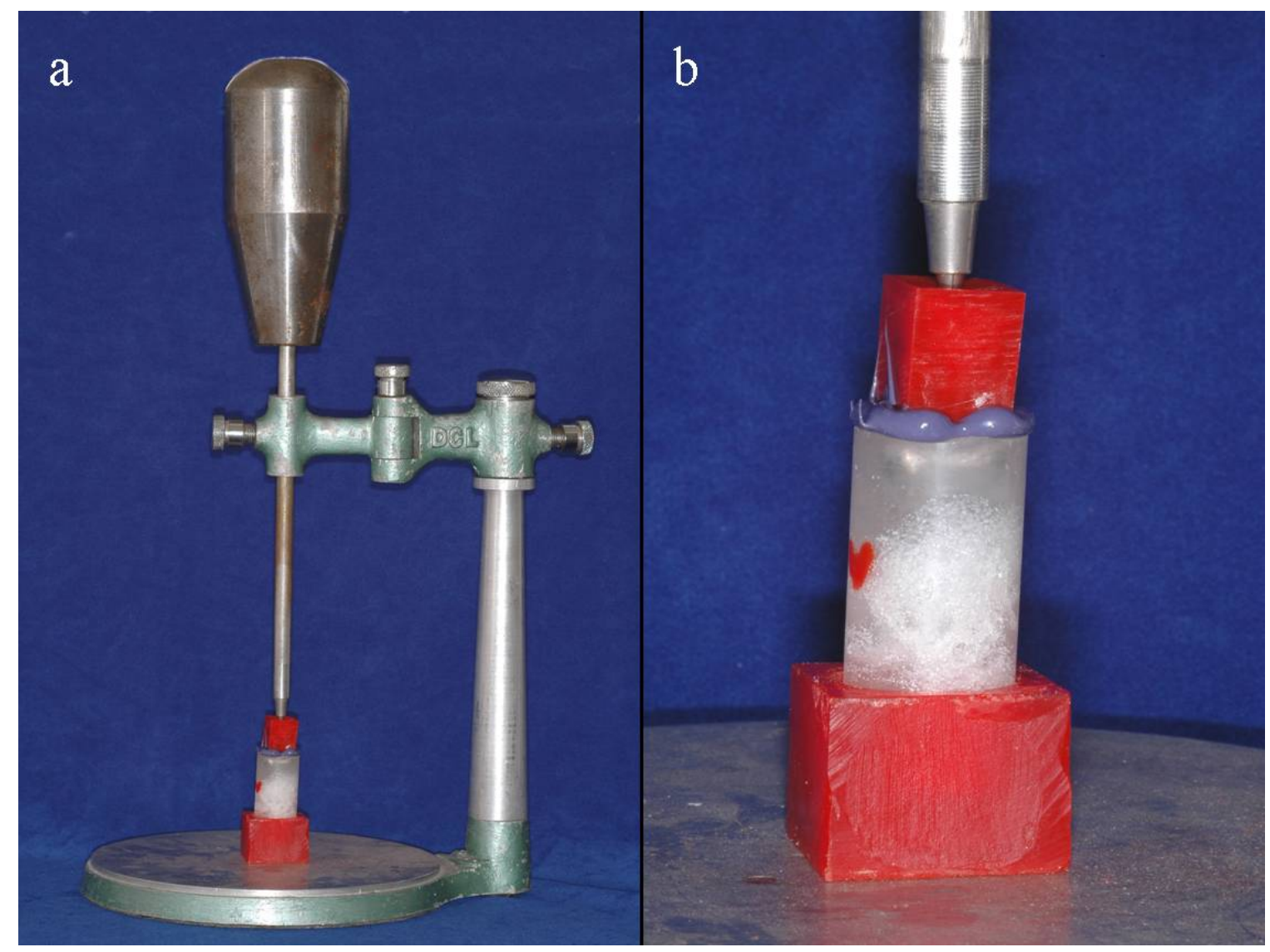

Figura 4.3 - Paralelômetro modificado com base acrílica encaixada e moldeira no troquel metálico (a); detalhe da carga estática mantida pelos dispositivos para carga (b)

Decorrido o tempo de polimerização do poliéter (8 minutos), a carga estática foi removida e as moldeiras individuais separada dos troquéismetálicos. Os moldes foram vazados com gesso tipo IV, utilizando-se a proporção de água e pó recomendada pelo fabricante. Após a cristalização do gesso (aproximadamente 60 minutos), os troquéis foram removidos e avaliados na sua reprodução.

Foram confeccionadas dez moldeiras individuais, sendo que cada uma delas foi utilizada quatro vezes (uma vez por grupo) na mesma seqüência descrita acima. Durante esta etapa, quando alguma área insatisfatória estivesse presente no molde ou troquel de gesso, os procedimentos eram repetidos até que estes fossem julgados satisfatórios. Ao todo, foram obtidos dez troquéis de gesso para cada troquel metálico (Figura 4.4). 


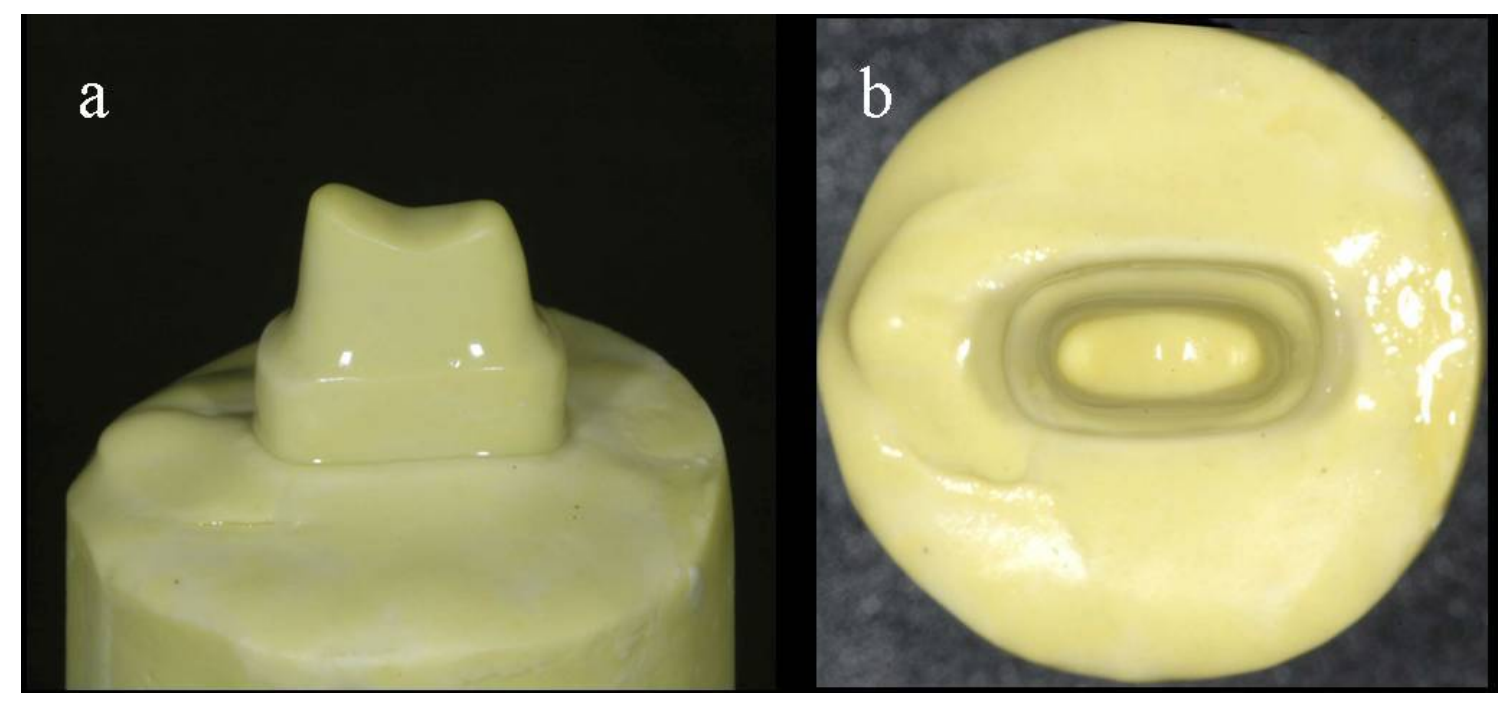

Figura 4.4 - Vista proximal (a) e oclusal (b) de um troquel de gesso tipo IV

\section{3 - OBTENÇÃO DAS INFRA-ESTRUTURAS}

Os 40 troquéis de gesso foram encaminhados para um laboratório comercial credenciado e familiarizado com a produção de coroas metalocerâmicas e ceramocerâmicas. Foram definidos quatro grupos experimentais cujas características se encontram descritas abaixo:

Grupo 1: obtenção de infra-estruturas de liga de níquel-cromo com desenho com reforço (cinta lingual e poste proximal) (Figura $4.5 \mathrm{a}, \mathrm{e}$ );

Grupo 2: obtenção de infra-estruturas de liga de níquel-cromo com desenho sem reforço (Figura $4.5 \mathrm{~b}, \mathrm{f}$ );

Grupo 3: obtenção de infra-estruturas de cerâmica In-Ceram Alumina, com desenho com reforço (cinta lingual e poste proximal) (Figura 4.5 c, g);

Grupo 4: obtenção de infra-estruturas de cerâmica In-Ceram Alumina com desenho sem reforço (Figura $4.5 \mathrm{~d}, \mathrm{~h}$ ).

Cada grupo era constituído por dez amostras $(n=10)$, totalizando 40 corpos de prova. 


\subsection{1 - DESENHO DAS INFRA-ESTRUTURAS}

O desenho das infra-estruturas com reforço, tanto para as metálicas de níquel-cromo (Figura 4.5 a, e), como para as de cerâmica de In-Ceram Alumina (Figura $4.5 \mathrm{c}, \mathrm{g}$ ), apresentava uma espessura variando de 0,3 mm a $0,5 \mathrm{~mm}$, assim como uma cinta na região lingual de $2,0 \mathrm{~mm}$ de altura, que se estendia para as faces proximais, e um poste proximal de $3,5 \mathrm{~mm}$ de altura e $1,0 \mathrm{~mm}$ de espessura, aproximadamente.

O desenho das infra-estruturas sem reforço, tanto para as metálicas de níquel-cromo (Figura 4.5 b, f) como para as de cerâmica de In-Ceram Alumina (Figura $4.5 \mathrm{~d}, \mathrm{~h}$ ), apresentava uma espessura variando de 0,3 a 0,5 mm, não apresentando a cinta lingual e o poste proximal.

Para a padronização das dimensões das infra-estruturas metálicas e cerâmicas foram realizadas duas matrizes divididas de gesso tipo IV (a primeira matriz para infra-estruturas com reforço e a segunda para infra-estruturas sem reforço), que foram utilizadas para a obtenção dos padrões de cera e de alumina, reproduzindo a metodologia utilizada por GUERRA ${ }^{26}$, em 1990.

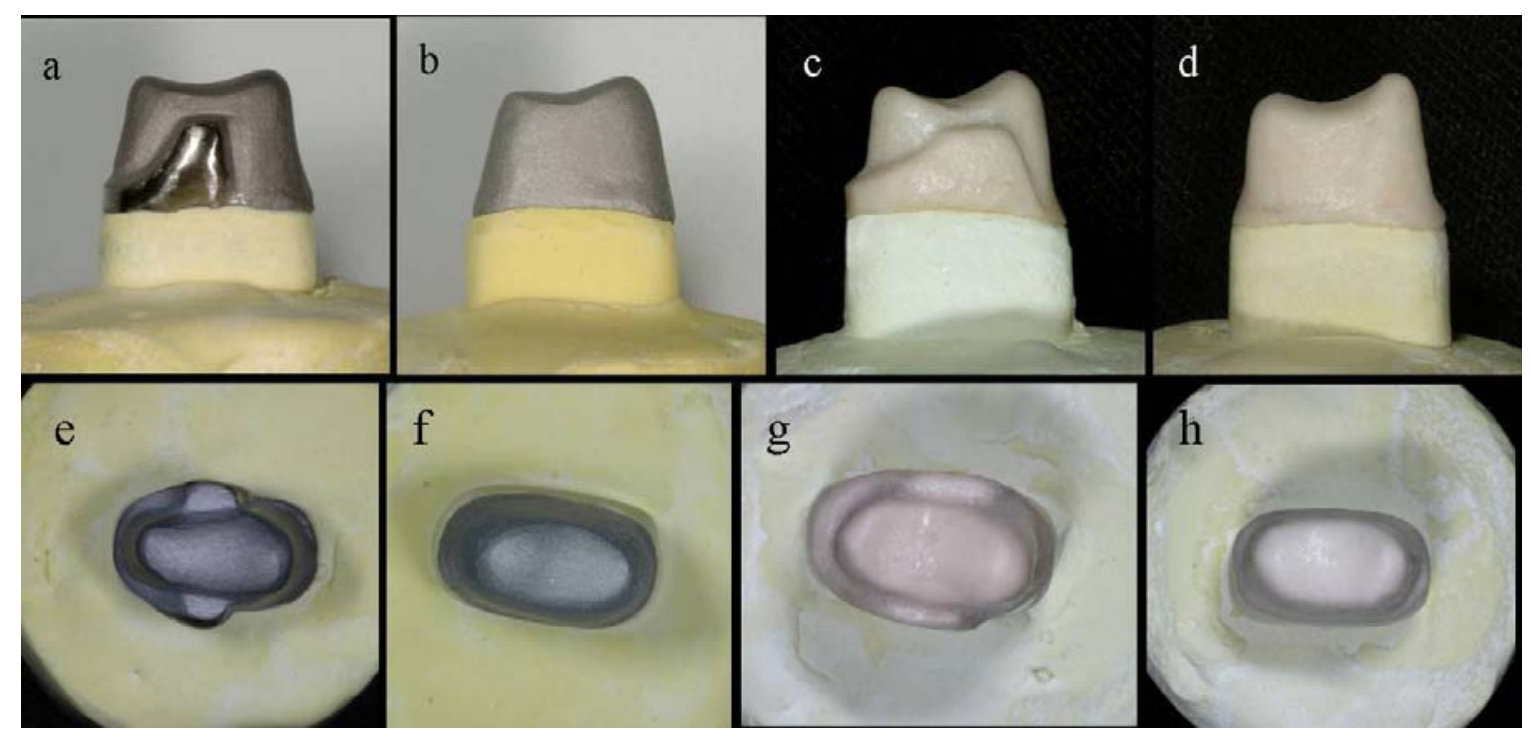

Figura 4.5 - Infra-estruturas metálicas de níquel-cromo com reforço $(a, e)$ e sem reforço (b, f); infra-estruturas cerâmicas In-Ceram Alumina com reforço (c, g) e sem reforço (d, h). Vista proximal (a-d) e vista oclusal (e-h) 


\subsection{2 - OBTENÇÃO DAS INFRA-ESTRUTURAS METÁLICAS}

\subsubsection{1 - Obtenção dos padrões de cera}

Os padrões de cera das infra-estruturas das coroas metalocerâmicas foram obtidos por técnica indireta, utilizando-se cera para fundição e isolamento dos troquéis com duas camadas de isolante próprio.

A cera foi liquefeita sobre a chama de uma lâmpada a álcool e aplicada no troquel por meio de instrumento PKT $\mathrm{n}^{\circ} 2$, envolvendo toda sua região e formando um fino casquete. Após escultura e acabamento, realizados com o instrumento $\mathrm{PKT} \mathrm{n}^{\circ} 4$, o padrão de cera foi removido do troquel e inspecionado, principalmente, para se avaliar a uniformidade da cera nas superfícies internas. A seguir, o padrão de cera foi novamente posicionado sobre o troquel e realizou-se o selamento marginal com o auxílio de uma lupa, sob aumento de quatro vezes $(4 \mathrm{x})$.

\subsubsection{2 - Inclusão e fundicãão}

Dois padrões de cera foram fixados a um fio de cera formador de conduto de alimentação para fundição, em $45^{\circ}$ em relação à face oclusal, na região línguo-oclusal do padrão. Em seguida, o padrão foi removido do troquel e fixado com cera liquefeita à base formadora de cadinho. Aplicou-se um agente redutor da tensão superficial em todo o padrão e fixou-se, na base formadora de cadinho, um anel de borracha para inclusão do revestimento.

Utilizou-se o revestimento Termocast, na proporção de $18 \mathrm{ml}$ de água para $100 \mathrm{~g}$ de pó, com manipulação e inclusão a vácuo em aparelho próprio, a uma pressão de 15 libras e 60 segundos de tempo de espatulação. Após a inclusão, o conjunto foi levado para uma câmara com pressão constante de dois bars. Passados 20 minutos, o anel de borracha e a base foram removidos do revestimento, permitindo sua expansão livre.

Decorridos 45 minutos da inclusão, o anel de revestimento foi colocado em forno elétrico com a entrada do cadinho voltada para baixo. Procedeu-se ao ciclo de aquecimento com elevação lenta da temperatura até $350^{\circ} \mathrm{C}$, mantendo-a por 1 hora. Inverteu-se o anel e se elevava a temperatura do forno até $850^{\circ} \mathrm{C}$, mantendo-a por 60 minutos. O cadinho para fundição também recebeu o mesmo ciclo de aquecimento do anel e, após armar-se a 
centrífuga, era posicionado em seu braço. O cadinho recebeu a liga Vera Bond II, em quantidade suficiente para ocorrer à fundição, realizada com maçarico gás-oxigênio, a 50 psi. Após a fusão da liga, o anel era retirado do forno e adaptado ao braço da centrífuga, que era imediatamente acionada. A seguir, o anel era removido do braço da centrífuga e aguardava-se o resfriamento completo para se proceder a desinclusão.

O revestimento foi removido por meio de lavagem com água corrente e escova, após o que se aplicava jato de óxido de alumínio de $50 \mu \mathrm{m}$ de diâmetro, por cerca de 5 segundos para complementar a limpeza do padrão fundido. Os condutos de alimentação foram secionados com discos de carborundum.

A superfície interna da infra-estrutura foi submetida a um exame minucioso com lupa, sob aumento de quatro vezes, para possibilitar a detecção de irregularidades, que foram removidas com brocas carbide esféricas $n^{\circ} 2 \mathrm{em}$ baixa rotação quando presentes.

A adaptação de cada uma das infra-estruturas metálicas foi avaliada sobre os troquéis-padrão metálicos que Ihes deram origem. Aquelas que não apresentavam assentamento adequado sobre seu troquel tinham seu interior ajustado com brocas carbide esféricas $\mathrm{n}^{\circ} 2$, em baixa rotação, nos pontos evidenciados pelo carbono líquido, spray Arti-Spot Red. O ajuste prosseguiu até que cada uma das coroas se assentasse, com o menor desajuste possível, sobre seu troquel.

\subsection{3 - OBTENÇÃO DAS INFRA-ESTRUTURAS CERÂMICAS}

Os troquéis de gesso para obtenção das infra-estruturas cerâmicas do sistema In-Ceram Alumina receberam a aplicação de uma camada do verniz espaçador do sistema, mantida a $1 \mathrm{~mm}$ da margem do preparo. Os troquéis foram duplicados com silicone de adição e os moldes vazados com o gesso específico do sistema. De acordo com a especificação do fabricante, após duas horas, os troquéis de trabalho foram removidos dos moldes e as bases recortadas a seco, propiciando uma superfície plana. As margens dos preparos foram delimitadas com grafite e os troquéis pincelados com uma fina camada 
de selador. Nessas condições, o conjunto estava pronto para receber a mistura In-Ceram Alumina.

\subsubsection{1 - Preparação da mistura}

Em um frasco de vidro apropriado verteu-se uma ampola de líquido de mistura In-Ceram Alumina e uma gota de aditivo In-Ceram Alumina. O frasco com os dois líquidos foi levado a um aparelho de ultra-som, Vitasonic II, para uma completa homogeneização.

Posteriormente a mistura foi colocada sobre um vibrador, adicionouse $38 \mathrm{~g}$ do pó In-Ceram Alumina lentamente e em pequenas porções, com a ajuda de uma espátula de vidro. Interrompe-se o procedimento por três vezes para colocar o frasco de vidro por dois minutos no aparelho de ultra-som. Finalizada a adição do pó, colocou-se o frasco de vidro por sete minutos novamente no aparelho de ultra-som. A suspensão foi agitada até se obtenha uma consistência regular e homogênea.

Em seguida, submeteu-se a mistura homogênea ao vácuo por um minuto. A aplicação da mistura In-Ceram Alumina sobre os troquéis foi feita com um pincel de pêlo sintético $n^{\circ} 4$.

Com uma lâmina de bisturi nova, procedeu-se á escultura da infraestrutura. Depois da escultura terminada, foi aplicada uma fina camada de estabilizante e prosseguiu-se com a sinterização.

\subsubsection{2 - Cocção de sinterização no forno Vita Inceramat}

- $\quad$ Aquecimento gradual: 6 horas a $150^{\circ} \mathrm{C}$.

- Aumento gradual de temperatura: 2 horas para atingir $1120^{\circ} \mathrm{C}$.

- $\quad$ Manutenção a $1120^{\circ} \mathrm{C}$ por 2 horas.

- Resfriamento até $400^{\circ} \mathrm{C}$ com o forno fechado.

- $\quad$ Abertura da porta do forno para resfriar até a temperatura ambiente.

Após a cocção, a infra-estrutura é facilmente separada do troquel, em função da contração deste, que ocorre durante o processo de sinterização. Pequenas correções da superfície externa deverão ser feitas nesse momento, 
com pontas diamantadas de granulação fina em baixa rotação. Pequenas trincas poderão ser detectadas com o auxílio do líquido (azul) para este fim, que acompanha o sistema. Se estas estiverem presentes, faz-se necessária a confecção de uma nova infra-estrutura.

A seguir, a mistura de pó de vidro e água destilada foi aplicada generosamente à superfície externa das infra-estruturas com um pincel. E esta foi, então, colocada sobre uma lâmina de platina para a cocção de infiltração.

\subsubsection{3 - Cocção de infiltração no forno Vita Inceramat}

- $\quad$ Aquecimento: 50 minutos para atingir $1140^{\circ} \mathrm{C}$

- $\quad$ Manutenção a $1.140{ }^{\circ} \mathrm{C}$ por 2 horas e trinta minutos.

- $\quad$ Resfriamento até $400^{\circ} \mathrm{C}$ com o forno fechado.

- $\quad$ Abre-se a porta do forno para resfriar até a temperatura ambiente.

Após a infiltração, as partículas de vidro excedente foram eliminadas com o auxílio de pontas diamantadas de granulação grossa, e logo depois foi jateada com óxido de alumínio de $50 \mu \mathrm{m}$ para eliminar os restos de vidro e ser novamente levada ao forno por 10 minutos a $960^{\circ} \mathrm{C}$. Um segundo jateamento com óxido de alumínio de $50 \mu \mathrm{m}$ foi efetuado para eliminar o vidro que eventualmente pode ter fluído.

Cada uma das infra-estruturas foi ajustada pelo técnico em prótese dentária sobre os respectivos troquéis metálicos originais e os ajustes, quando necessários, foram feitos com pontas diamantadas esféricas em motor elétrico.

\section{4 - APLICAÇÃO DA PORCELANA}

\subsection{1 - APLICAÇÃO E COCÇÃO DA PORCELANA SOBRE AS INFRA- ESTRUTURAS METÁLICAS}

Para a aplicação do opaco e do revestimento cerâmico nas infraestruturas metálicas foi utilizada a porcelana Noritake Super Porcelain EX-3, seguindo as especificações do fabricante. 
A aplicação da porcelana opaca foi realizada em duas etapas: inicialmente aplicou-se uma fina camada sobre o metal, por meio de um pincel e vibração, seguida de um pré-aquecimento por 8 minutos a $400^{\circ} \mathrm{C}$ com o forno aberto para secagem. A temperatura foi elevada $65^{\circ} \mathrm{C}$ por minuto até atingir $980^{\circ} \mathrm{C}$, que foi mantida por 1 minuto. A seguir, foi aplicada a segunda camada de porcelana opaca, e as infra-estruturas metálicas foram pré-aquecidas por 8 minutos e levadas a um forno a $400^{\circ} \mathrm{C}$, cuja temperatura aumentava $65^{\circ} \mathrm{C}$ por minuto, até atingir a temperatura máxima de $980^{\circ} \mathrm{C}$ a vácuo, sendo aí mantida por 1 minuto. Quando completado o ciclo, o resfriamento dos corpos de prova foi realizado a temperatura ambiente.

A aplicação de porcelana de dentina e esmalte foi realizada em pequenas porções, dando a anatomia de um pré-molar superior. Cuidados foram tomados na sua condensação e na eliminação do excesso de líquido com papel absorvente. A cocção realizada sob vácuo foi precedida de um préaquecimento por 8 minutos a $600^{\circ} \mathrm{C}$ com o forno aberto para secagem da porcelana. A temperatura foi elevada em $45^{\circ} \mathrm{C}$ por minuto, até atingir a temperatura máxima de $920^{\circ} \mathrm{C}$ a vácuo, sendo mantida por 1 minuto.

Após a queima da cerâmica, as coroas foram retiradas do forno, aguardando-se o resfriamento delas á temperatura ambiente, quando então o acabamento destas coroas foi realizado. Posteriormente, foi realizada a aplicação da camada de glaze, finalizando o procedimento com a terceira queima. Para tanto, os corpos de prova foram levados ao forno aberto por 5 minutos, para secagem. Após esse tempo foram queimados a $650^{\circ} \mathrm{C}$, subindo $130^{\circ} \mathrm{C}$ por minuto, até atingir a temperatura máxima de $930^{\circ} \mathrm{C}$, sendo mantida por 1 minuto. Após a queima do glaze, as coroas foram retiradas do forno, aguardando-se o resfriamento a temperatura ambiente (Figura $4.7 \mathrm{a}, \mathrm{b}$ ).

A padronização das espessuras de cerâmica aplicada foi realizada por meio de uma matriz dividida, construída em silicona de condensação de massa densa para padronizar a forma de pré-molar da coroa e a espessura da porcelana aplicada nas infra-estruturas, seguindo a metodologia empregada por GUERRA ${ }^{26}$, em 1990, (Figura 4.6). 


\subsection{2 - APLICAÇÃO E COCÇÃO DA PORCELANA SOBRE AS INFRA- ESTRUTURAS CERÂMICAS}

As infra-estruturas cerâmicas (In-Ceram Alumina) foram revestidas com porcelana Noritake Cerabien, segundo as instruções do fabricante.

O revestimento das infra-estruturas cerâmicas iniciou-se pela aplicação da primeira camada de porcelana opaca. Para tanto, utilizou-se um pincel fino, com a finalidade de se aplicar pequenas quantidades do material, começando pela região cervical até envolver toda a superfície uniformemente. Depois da aplicação da primeira camada de porcelana, as coroas foram submetidas a primeira queima, sendo os corpos de prova levados ao forno aberto por 6 minutos, para secagem. Após esse tempo, a porcelana foi queimada num ciclo térmico de $600^{\circ} \mathrm{C}$, subindo $50^{\circ} \mathrm{C}$ por minuto, até atingir a temperatura máxima de $1030^{\circ} \mathrm{C}$, que foi mantida por 4 minutos. Quando completado o ciclo, o forno desligou-se automaticamente para o resfriamento em temperatura ambiente.

Após a primeira queima, aplicou-se uma camada de dentina e de esmalte em pequenas porções para completar a forma e a superfície oclusal, obtendo-se a anatomia de um pré-molar superior sempre orientado pela matriz de silicona. Tomou-se cuidado para que não fosse aplicado material em excesso nas margens e, quando foi completada a aplicação da porcelana, removeu-se o excesso de umidade com papel absorvente. O formato da coroa foi concretizado em tamanho maior para compensar a contração produzida pela queima. Assim, as coroas foram submetidas a segunda queima, levando os corpos de prova ao forno aberto por 8 minutos, para secagem. Após esse tempo, a porcelana foi queimada num ciclo térmico de $600^{\circ} \mathrm{C}$, subindo $45^{\circ} \mathrm{C}$ por minuto, até atingir a temperatura máxima de $960^{\circ} \mathrm{C}$ a vácuo, que foi mantida por 4 minutos. Quando completado o ciclo, o forno desligou-se automaticamente para resfriamento a temperatura ambiente.

Após a segunda queima, o acabamento das coroas foi realizado por meio de uma uniformização da superfície e posteriormente foi realizada a aplicação da camada de glaze, finalizando o procedimento com a terceira queima. Para tanto, os corpos de prova foram levados ao forno aberto por 5 minutos, para secagem. Após esse tempo, os corpos de prova com glaze foram 
queimados a $600^{\circ} \mathrm{C}$, subindo $130^{\circ} \mathrm{C}$ por minuto, até atingir a temperatura máxima de $960^{\circ} \mathrm{C}$, que foi mantida por 4 minutos. Quando completado o ciclo, o forno desligou-se automaticamente para o resfriamento a temperatura ambiente.

A padronização das espessuras de cerâmica aplicada foi realizada por meio de uma matriz dividida, construída em silicona de condensação de massa densa para padronizar a forma de pré-molar da coroa e a espessura da porcelana aplicada nas infra-estruturas, seguindo a metodologia empregada por GUERRA ${ }^{26}$, em 1990 (Figura 4.6).

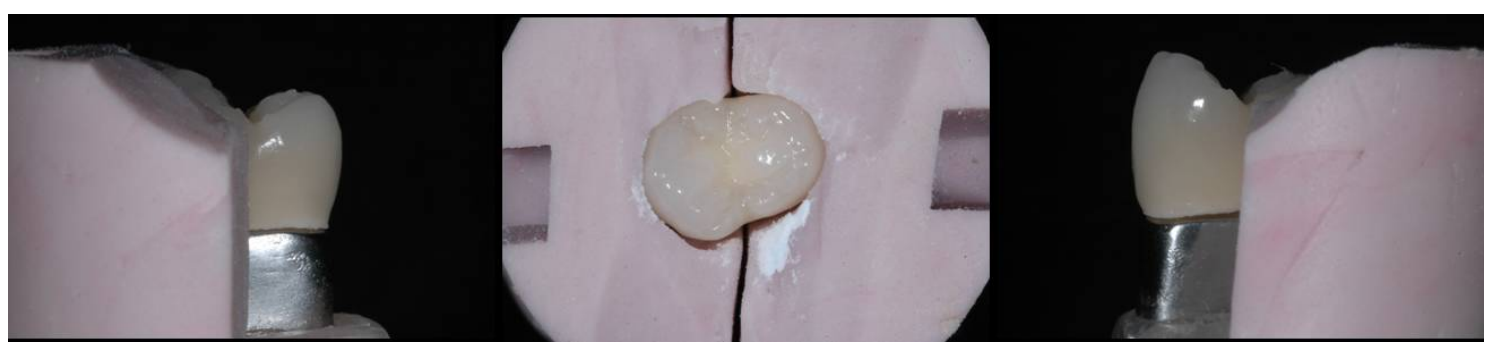

Figura 4.6 - Matriz de silicona para padronização da espessura de porcelana

Após a aplicação e cocção da porcelana de revestimento, as superfícies internas das coroas foram jateadas com óxido de alumínio de 50 $\mu \mathrm{m}$ a uma pressão de 3 bars aproximadamente (Figura 4.7 c, d).

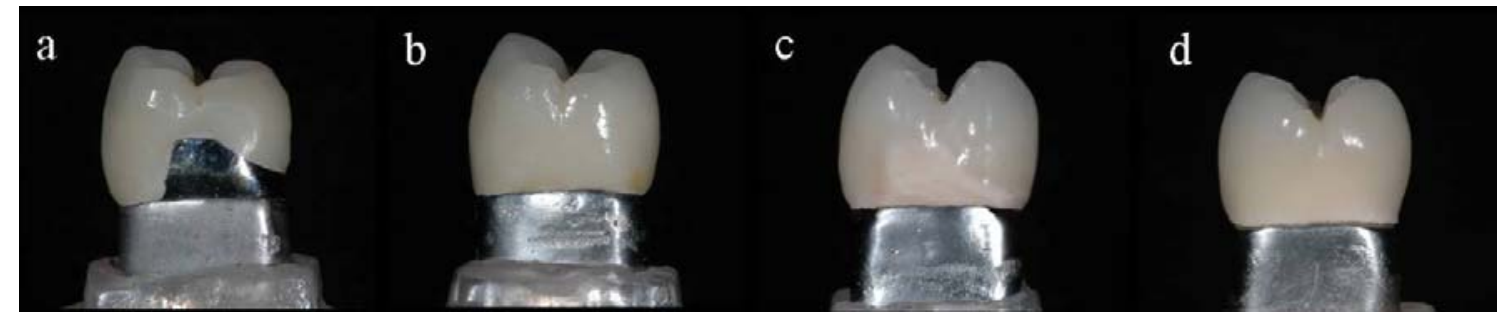

Figura 4.7 - Coroas metalocerâmicas com reforço (a) e sem reforço (b); coroas ceramocerâmicas com reforço (c) e sem reforço (d) 


\section{5 - CIMENTAÇÃO DOS CORPOS DE PROVA}

Os 40 corpos de prova dos 4 grupos foram cimentados com ionômero de vidro modificado por resina nos troquéis-padrão metálicos. O cimento foi manipulado num bloco de papel seguindo as instruções do fabricante e a mistura obtida foi pincelada numa fina camada na superfície interna das coroas, que foram levadas aos troquéis-padrão metálicos de cada grupo e assentadas sob pressão digital. Em seguida, o conjunto foi levado ao paralelômetro modificado e recebeu carga estática de $2 \mathrm{~kg}$, mantida por 10 minutos. Durante este tempo ocorreu a completa polimerização do cimento e os excessos dele foram removidos com auxílio de uma lâmina de bisturi no 15 . Em seguida, todos os corpos de prova foram mantidos durante 24 horas, a $100 \%$ de umidade a $37^{\circ} \mathrm{C}$, sendo imediatamente submetidos aos testes de resistência à fratura. Previamente à cimentação, cada troquel metálico foi isolado com o objetivo de facilitar a remoção da coroa após o teste de resistência à fratura, sem danos para o troquel.

\section{6 - TESTES DE RESISTÊNCIA À FRATURA}

Os testes de resistência à fratura por compressão axial foram realizados com auxílio de uma máquina universal de testes Kratos, onde foi acoplada uma célula de carga de $500 \mathrm{kgf}$, regulada a uma velocidade de 0,5 mm/min. Um dispositivo especial metálico (Figura 4.8 a) acoplado à porção inferior da máquina Kratos permitiu a colocação do corpo de prova durante a execução dos testes, possibilitando que a coroa ficasse posicionada em uma inclinação de $90^{\circ}$ em relação ao plano horizontal (Figura 4.8 b). A transmissão de força foi feita por meio de um cilindro de aço com 8,0 $\mathrm{mm}$ de diâmetro adaptada a parte superior da máquina de testes Kratos (Figura $4.8 \mathrm{c}$ ). O ponto de aplicação da força foi sempre o mesmo em todos os corpos de prova, nas duas vertentes internas das cúspides de cada coroa (Figura 4.8 d) assegurando, assim, que a distribuição das cargas fosse sempre semelhante e na mesma direção. 
A máquina de ensaios foi programada de forma que a carga era automaticamente descontinuada (paralisação da máquina) quando o sistema falhasse, o seja, fratura da cerâmica de revestimento ou fratura da cerâmica de revestimento junto com a fratura da infra-estrutura.

Realizou-se o teste de resistência à fratura em cada corpo de prova, registrando-se a máxima força requerida para sua fratura.

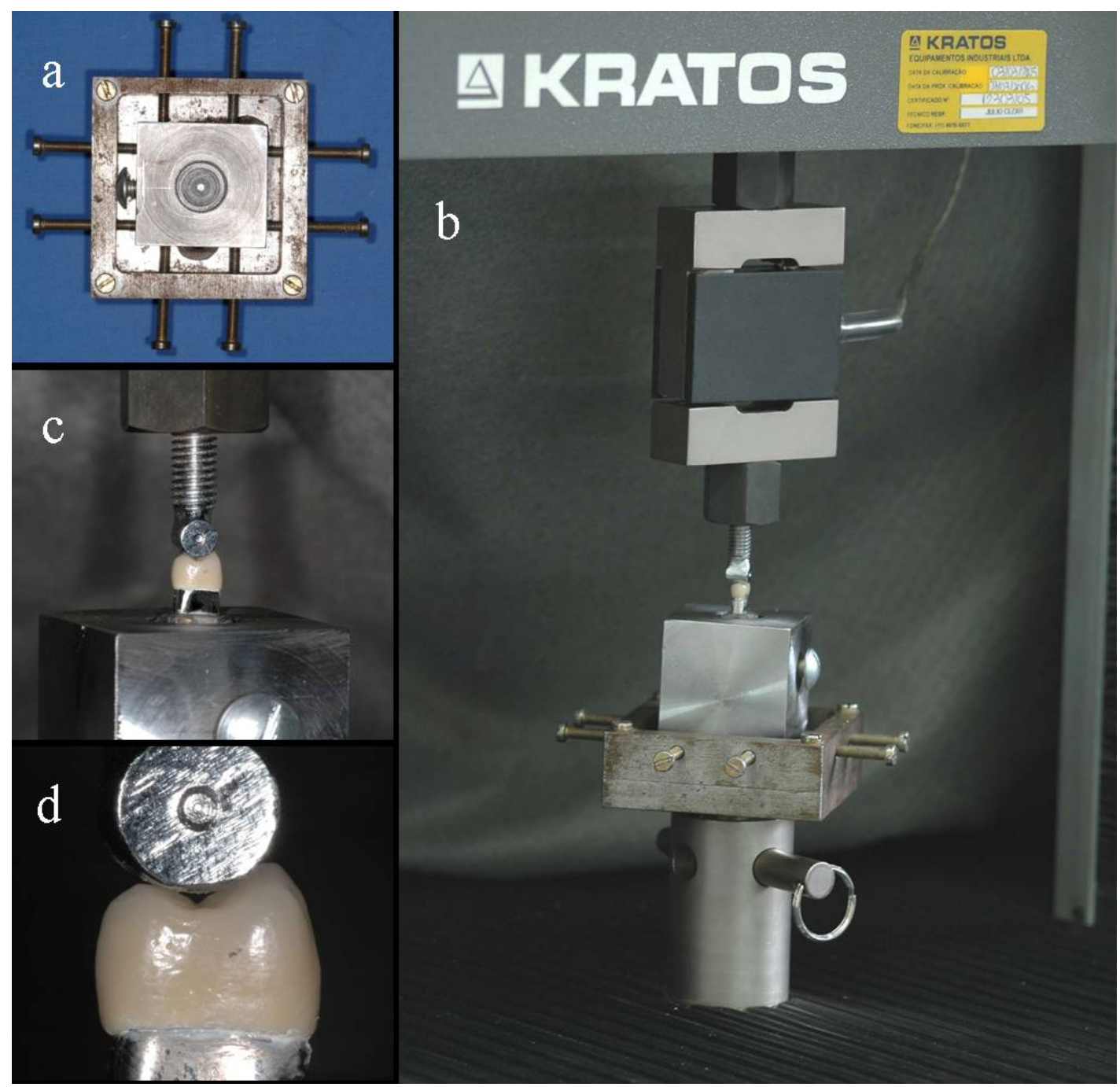

Figura 4.8 - Base metálica para fixação do troquel metálico (a); parte da máquina de testes universal Kratos com a base metálica acoplada (b); cilindro de aço em contato com o corpo de prova (c); detalhe do cilindro de aço em contato com as duas vertentes internas das cúspides da coroa (d) 


\subsection{1 - REGISTRO DO LIMIAR DE FALHA}

Para todos os corpos de prova foi registrado o limiar de falha, que é a carga máxima que o corpo de prova pode suportar antes que ocorra algum tipo de falha (fratura da cerâmica de revestimento ou fratura da cerâmica de revestimento junto com a fratura da infra-estrutura) (ANUSAVICE $\left.{ }^{3}, 2005\right)$.

O limiar de falha e o gráfico de aplicação das forças representadas no monitor do computador acoplado à máquina de ensaios, posteriormente impressos e os valores organizados em tabelas.

\subsection{2 - ANÁLISE DOS CORPOS DE PROVA FRATURADOS}

O tipo de fratura dos corpos de prova foi registrado por meio de análise visual das coroas metalocerâmicas e ceramocerâmicas com e sem reforço na sua infra-estrutura.

\section{7 - ANÁLISE ESTATÍSTICA}

Os resultados encontrados dos testes de resistência à fratura dos 40 corpos de prova dos 4 grupos, foram submetidos à análise de variância (ANOVA) a dois critérios (desenho da infra-estrutura e material da infraestrutura) e a análise de Tukey. O nível de significância considerado em todas as análises foi de $5 \%(p<0,05)$. 


\section{5 - RESULTADOS}




\section{5 - RESULTADOS}

O valor de resistência à fratura (kgf) obtido para cada corpo de prova e as médias e os respectivos desvios padrão para os diferentes grupos de coroas, após os ensaios na máquina de testes universal Kratos, são apresentados na tabela 5.1.

Tabela 5.1 - Valores de resistência à fratura (kgf) para cada corpo de prova e médias e respectivos desvios padrão para os grupos de coroas metalocerâmicas e ceramocerâmicas, com e sem reforço na infra-estrutura

\begin{tabular}{ccccc}
\hline $\begin{array}{c}\text { Corpos de } \\
\text { prova }\end{array}$ & $\begin{array}{c}\text { Coroas } \\
\text { metalocerâmicas } \\
\text { com reforço }\end{array}$ & $\begin{array}{c}\text { Coroas } \\
\text { metalocerâmicas } \\
\text { sem reforço }\end{array}$ & $\begin{array}{c}\text { Coroas } \\
\text { ceramocerâmicas } \\
\text { com reforço }\end{array}$ & $\begin{array}{c}\text { Coroas } \\
\text { metalocerâmicas } \\
\text { sem reforço }\end{array}$ \\
\hline $\mathbf{1}$ & 221,750 & 156,125 & 106,875 & 90,885 \\
\hline $\mathbf{2}$ & 205,500 & 187,625 & 120,875 & 78,500 \\
\hline $\mathbf{3}$ & 263,500 & 172,125 & 129,150 & 108,375 \\
\hline $\mathbf{4}$ & 219,750 & 154,125 & 115,625 & 88,250 \\
\hline $\mathbf{5}$ & 234,000 & 202,750 & 133,350 & 101,375 \\
\hline $\mathbf{6}$ & 234,750 & 146,875 & 150,250 & 112,000 \\
\hline $\mathbf{7}$ & 228,875 & 198,000 & 119,500 & 93,875 \\
\hline $\mathbf{8}$ & 237,250 & 164,750 & 156,125 & 112,500 \\
\hline $\mathbf{9}$ & 286,000 & 155,885 & 121,880 & 55,500 \\
\hline $\mathbf{1 0}$ & 245,000 & 179,125 & 122,250 & 97,885 \\
\hline Média & 237,637 & 171,738 & 127,588 & 93,914 \\
\hline $\begin{array}{c}\text { Desvio } \\
\text { padrão }\end{array}$ & 23,011 & 19,524 & 15,302 & 17,345 \\
\hline & & & & \\
\hline
\end{tabular}


As médias de resistência à fratura e desvios padrão dos grupos experimentais estão mostrados na tabela 5.2 e na figura 5.1 .

Tabela 5.2 - Médias de resistência à fratura (kgf) e respectivos desvios padrão para coroas metalocerâmicas com reforço (Grupo 1) e sem reforço (Grupo 2), e coroas ceramocerâmicas com reforço (Grupo 3) e sem reforço (Grupo 4)

\begin{tabular}{lcc}
\hline \multicolumn{1}{c}{ Grupos } & Média & Desvio padrão \\
\hline $\begin{array}{l}\text { Coroas } \\
\text { metalocerâmicas } \\
\text { Com reforço (1) }\end{array}$ & 237,637 & 23,011 \\
$\begin{array}{l}\text { Coroas } \\
\text { metalocerâmicas } \\
\text { Sem reforço (2) }\end{array}$ & 171,738 & 19,524 \\
$\begin{array}{l}\text { Coroas } \\
\text { ceramocerâmicas } \\
\text { Com reforço (3) }\end{array}$ & 127,588 & 15,302 \\
\hline $\begin{array}{l}\text { Coroas } \\
\text { ceramocerâmicas } \\
\text { Sem reforço (4) }\end{array}$ & 93,914 & 17,345 \\
\hline
\end{tabular}

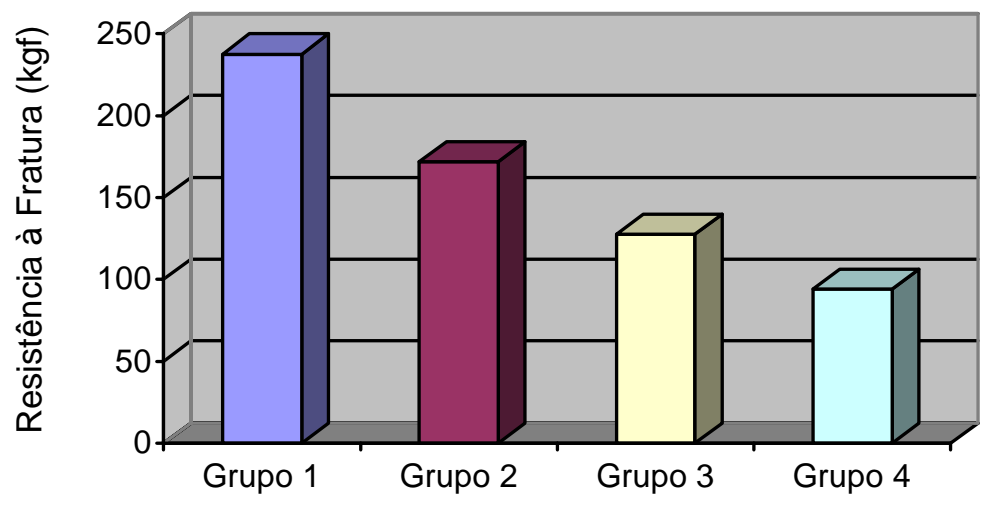

Figura 5.1 - Média de resistência à fratura das coroas metalocerâmicas com reforço (Grupo 1) e sem reforço (Grupo 2); e das coroas ceramocerâmicas com reforço (Grupo 3) e sem reforço (Grupo 4) 
O teste de análise de variância (ANOVA) a dois critérios (1= material da infra-estrutura: níquel-cromo e In-Ceram Alumina; 2= Presença de reforço: cinta lingual e poste proximal) demonstrou existir diferença estatisticamente significante $(p<0,05)$ entre os valores de resistência à fratura dos corpos de prova (Tabela 5.3).

Tabela 5.3 - Análise de variância (ANOVA) a dois critérios (1= Material da infra-estrutura: níquel-cromo e In-Ceram Alumina; 2= Presença de reforço: cinta lingual e poste proximal) para os valores de resistência à fratura dos corpos de prova

\begin{tabular}{lccccccc}
\hline & $\begin{array}{c}\text { Graus de } \\
\text { Liberdade }\end{array}$ & $\begin{array}{c}\text { Quadrado } \\
\text { Médio }\end{array}$ & $\begin{array}{c}\text { Graus de } \\
\text { Liberdade }\end{array}$ & $\begin{array}{c}\text { Quadrado } \\
\text { Médio }\end{array}$ & & \\
& Efeito & Efeito & Erro & Erro & F & $\begin{array}{c}\text { Probabilidade } \\
(\mathrm{p})\end{array}$ \\
\hline $\mathbf{1}$ Material & 1 & 888241,13 & 36 & 361,4278 & 244,1459 & $0,0000^{*}$ \\
\hline 2 Reforço & 1 & 24786,71 & 36 & 361,4278 & 68,57996 & $0,0000^{*}$ \\
\hline $\mathbf{1}$ e 2 & 1 & 2596,207 & 36 & 361,4278 & 7,183197 & $0,0110^{*}$ \\
\hline
\end{tabular}

* Diferença estatisticamente significante $(p<0,05)$

O teste de Tukey foi aplicado para comparações múltiplas, visando localizar as diferenças entre as médias dos valores de resistência à fratura (kgf) dos grupos de coroas metalocerâmicas com reforço (1), coroas metalocerâmicas sem reforço (2), coroas ceramocerâmicas com reforço (3) e coroas ceramocerâmicas sem reforço (4) (Tabela 5.4). O teste de Tukey revelou a existência de diferenças estatisticamente $(p<0,05)$ na comparação aos pares, de cada grupo com cada um dos demais. 
Tabela 5.4 - Teste de TUKEY para comparações múltiplas entre as médias dos valores de resistência à fratura (kgf) entre todos os grupos: coroas metalocerâmicas com reforço (1), coroas metalocerâmicas sem reforço (2), coroas ceramocerâmicas com reforço (3) e coroas ceramocerâmicas sem reforço (4)

Interação 1 × 2

(1)

(2)

(3)

(4)

\begin{tabular}{lcccc}
\hline \multicolumn{1}{c}{ Média } & 237,637 & 171,738 & 127,588 & 93,914 \\
$\begin{array}{l}\text { Coroas } \\
\text { metalocerâmicas } \\
\text { com reforço (1) }\end{array}$ & $0,0002^{*}$ & $0,0002^{*}$ & $0,0002^{*}$ \\
$\begin{array}{l}\text { Coroas } \\
\text { metalocerâmicas } \\
\text { sem reforço (2) }\end{array}$ & $0,0002^{*}$ & $0,0002^{*}$ & $0,0002^{*}$ \\
$\begin{array}{l}\text { Coroas } \\
\text { ceramocerâmicas } \\
\text { com reforço (3) }\end{array}$ & $0,0002^{*}$ & $0,0002^{*}$ & & $0,0020^{*}$ \\
$\begin{array}{l}\text { Coroas } \\
\text { ceramocerâmicas } \\
\text { sem reforço (4) }\end{array}$ & $0,0002^{*}$ & $0,0002^{*}$ & $0,0020^{*}$ & \\
\hline * Diferença estatisticamente significante $(p<0,05)$ & & \\
\hline
\end{tabular}

* Diferença estatisticamente significante $(p<0,05)$

Evidenciou-se comportamento diferente no tipo de fratura nos materiais testados. A fratura das coroas metalocerâmicas foi exclusivamente da porcelana de revestimento e a das coroas ceramocerâmicas foi correspondente à porcelana de revestimento junto com a infra-estrutura (Figura 5.2).

As coroas metalocerâmicas com e sem reforço apresentaram fratura similar na porcelana de revestimento, que ocorreu em uma das duas cúspides a partir do ponto de transmissão de força pela ponta cilíndrica de aço, estendendo-se até a parte cervical das coroas (Figura 5.2 a, b). Aparentemente, na fratura das coroas metalocerâmicas sem reforço, a área exposta da infra-estrutura foi maior quando comparada à do grupo com reforço. 
As coroas ceramocerâmicas com reforço apresentaram fratura resultou na divisão mesio-distal das coroas (Figura 5.2 c). As coroas ceramocerâmicas sem reforço, por sua vez, apresentaram fratura cominutiva, resultando em fragmentação múltipla das coroas (Figura 5.2 d).

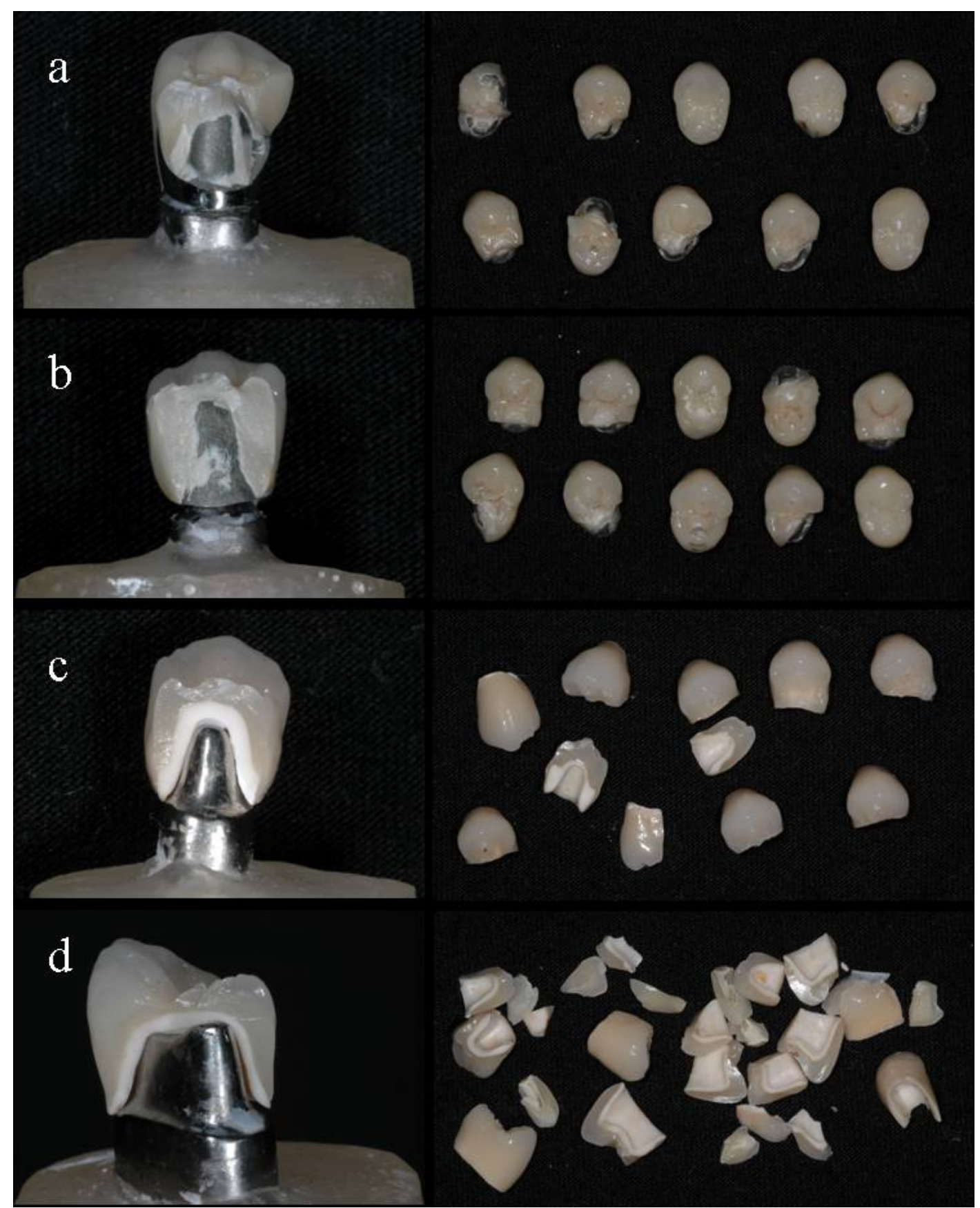

Figura 5.2 - Aspecto das coroas fraturadas. As imagens à esquerda mostram uma das coroas com fratura de cada grupo, em maior aumento. Coroas metalocerâmicas com reforço (a) e sem reforço (b); coroas ceramocerâmicas com reforço (c) e sem reforço (d) 


\section{6 - DISCUSSÃO}




\section{6 - DISCUSSÃO}

Durante as últimas décadas, o uso de ligas básicas como as de níquel-cromo e cobalto-cromo em substituição às ligas de ouro na fabricação das infra-estruturas de próteses fixas ganhou grande espaço, impulsionado principalmente pela vantagem financeira trazida por esta mudança (ANUSAVICE ${ }^{3}$, 2005, CHICHE; PINAULT ${ }^{11}$, 1994, HOBO; SHILLINGBURG ${ }^{29}$, 1973, MILLER ${ }^{56}, 1977$, NAYLOR $^{61}$, 1992). A consagração das restaurações metálicas indiretas fundamenta-se nos resultados clínicos favoráveis relatados na literatura e evidenciado por sua aplicação através dos anos, em todo o mundo (CHICHE; PINAULT ${ }^{11}$, 1994, GREY; PIDDOCK; WILSON ${ }^{23}, 1993$, HOBO $^{28}$, 1983, JOSEPHSON et al. ${ }^{34}, 1991$, NAYLOR ${ }^{61}$, 1992, RAMOS JUNIOR; BATISTA; MIRANDA $\left.{ }^{76}, 1997\right)$. Dessa forma, é inevitável que qualquer material inovador que venha a ser apresentado como substituto do metal nas próteses fixas, deva ser comparado ao sistema metalocerâmico.

As tradicionais coroas metalocerâmicas satisfazem à demanda da alta resistência requerida pela cavidade oral, mas estas restaurações apresentam deficiência estética como a presença de sombra do metal na área gengival, assim como reações de hipersensibilidade causadas pelas ligas metálicas (CASTELLANI et al. ${ }^{10}, 1994$, CHICHE; PINAULT ${ }^{11}$, 1994, RAMOS JUNIOR; BATISTA; MIRANDA ${ }^{76}, 1997$, THOMPSON; REKOW $\left.{ }^{96}, 2004\right)$. Por sua vez, o sistema ceramocerâmico possui qualidades estéticas superiores às do sistema metalocerâmico, contudo, apresenta características relacionadas à resistência que limitam o seu uso às áreas de menor incidência de forças, como na região anterior da cavidade oral (JOSEPHSON et al. ${ }^{34}, 1991$, $\operatorname{MCLEAN}^{47}, 1967, \operatorname{MCLEAN}^{45}, 1998$, MCLEAN $^{46}, 2001$, McLEAN; HUGHES ${ }^{51}$, 1965, MCLEAN; KEDGE ${ }^{54}$, 1987, POLIKET; CHICHE; FINGER ${ }^{68}, 2004$, STRUB; BESCHNIDT ${ }^{94}$, 1998).

A resistência está relacionada às propriedades de dureza dos materiais, desenho da infra-estrutura, espessura da porcelana, porosidade, geometria, módulo de elasticidade, rigidez de suporte, coeficiente térmico de expansão e integridade marginal (CASTELLANI et al. ${ }^{10}$, 1994, CHICHE; 
PINAULT ${ }^{11}, 1994$, MILLER $^{56}, 1977$, NAYLOR $^{61}, 1992$, THOMPSON; REKOW $^{96}$, 2004). Vale ressaltar que o sistema metalocerâmico foi extensamente pesquisado, apresentando uma excelente taxa de sucesso a longo prazo, quando os requisitos do desenho da infra-estrutura são aplicados de forma adequada (BERGER ${ }^{6}$, 1989, CHICHE; PINAULT ${ }^{11}$, 1994, CRAIG; ELEBRASHI; PEYTON ${ }^{14}$, 1971, HOBO; SHILLINGBURG ${ }^{29}, 1973$, HUDSON $^{33}$, 1959, KORNFELD ${ }^{36}, 1974$, KUWATA $^{38}, 1988$, MCLEAN $^{49}, 1983$, McLEAN $^{45}$, 1998, McLEAN; KEDGE ${ }^{54}, 1988$, MILLER $^{56}, 1977$, MUMFORD $^{58}, 1965$, NAYLOR ${ }^{61}$, 1992, RAMOS JUNIOR; BATISTA; MIRANDA ${ }^{76}$, 1997 , ROSENSTIEL; LAND; FUJIMOTO ${ }^{78}$, 2002, SGRÒ ${ }^{84}$, 2002, SHELBY ${ }^{85}, 1962$, SOZIO $^{90}$, 1977, STEIN; KUWATA ${ }^{92}$, 1977, STRAUSSBERG; KATZ; KUWATA $^{93}, 1966$, WARPEHA; GOODKIND ${ }^{104}$, 1976, WEISS ${ }^{106}$, 1977).

Para avaliar a resistência à fratura dos materiais utilizados na confecção das restaurações ceramocerâmicas, tem sido normalmente utilizado o teste de carga de 3 pontos (ANDERSSON; ODEN ${ }^{2}, 1993$, BAN; ANUSAVICE $^{5}, 1990$, NEIVA et al. ${ }^{62}$, 1998, PROBSTER; DIEHL ${ }^{73}, 1992$, SEGHI ${ }^{83}$, 1995, SEGHI; DAHER; CAPUTO ${ }^{82}$, 1990, WAGNER; $\mathrm{CHU}^{101}$, 1996, WOHLWEND; STRUB; SCHARER ${ }^{107}$, 1989, ZENG; ODEN; ROWCLIFFE ${ }^{109}$, 1996), em que o corpo de prova de forma retangular é apoiado em suas extremidades com a força incidindo em sua porção central. Podem ainda ser utilizadas avaliações por meio de análise com elemento finito bidimensional (MAGNE et al. ${ }^{41}, 2002$, PROOS et al. ${ }^{74}$, 2002) ou tridimensional (POSPIECH et al. $\left.{ }^{69}, 1996\right)$. Vale ressaltar que estes testes de resistência realizados com as metodologias acima descritas não têm levado em consideração a influência do desenho da infra-estrutura das restaurações. Geralmente foram testados corpos de prova com formas simples, nos quais a morfologia da porcelana não foi considerada (ORAM; DAVIES; CRUICKSHANKS-BOYD ${ }^{65}$, 1984).

As cerâmicas odontológicas apresentam grande resistência à carga compressiva, mas tendem a sucumbir à tensão de tração e cisalhamento (ANUSAVICE $^{3}, 2005$, ARAUJO $^{4}, 2000$, HUDSON$^{33}, 1959$, McLEAN $^{49}, 1983$, ROSENSTIEL; LAND; FUJIMOTO ${ }^{78}$, 2002), portanto, as características do desenho da infra-estrutura são de grande importância para compensar as desvantagens da friabilidade das cerâmicas odontológicas (CHICHE; 
PINAULT ${ }^{11}, 1994$, McLEAN $^{48}, 1990$, NAYLOR $^{61}$, 1992, ROSENSTIEL; LAND; FUJIMOTO $^{78}$, 2002).

A análise dos resultados deste estudo (Tabela 5.1) mostrou diferença estatisticamente significante, entre os materiais utilizados para confecção das infra-estruturas e a presença ou ausência de reforço (Tabela 5.3). Quando foi aplicado o teste de Tukey, os resultados mostraram diferenças estatisticamente significante entre todos os grupos (Tabela 5.4).

Observa-se que a resistência à fratura das coroas metalocerâmicas com reforço $(237,588 \mathrm{kgf})$ apresentou valores aproximadamente $86 \%$ maiores daqueles obtidos para as coroas ceramocerâmicas com o mesmo desenho $(127,588$ kgf). Apesar das limitações da metodologia empregada neste estudo, estes dados parecem justificar o excelente comportamento a longo prazo dessas coroas na cavidade oral, não apenas pelo reforço da porcelana proporcionado pelo metal, mas também pela proteção interna da porcelana devido à propagação de micro-fraturas (McLEAN $\left.{ }^{48}, 1990\right)$.

$\mathrm{Na}$ ausência de reforço nas infra-estruturas, as coroas metalocerâmicas apresentaram valores médios de 171,738 kgf, enquanto as coroas ceramocerâmicas apresentaram média de 93,914 kgf, diferença esta de 83,8\% e estatisticamente significante. Numa inferência clínica é lógico supor que grande parte das infra-estruturas das coroas metalocerâmicas não apresentam características ideais de reforço lingual e poste proximal, como as aqui testadas e, apesar disso, mostram excelente comportamento a longo prazo (CAMPBELL ${ }^{9}, 1989$, COORNAERT; ADRIAENS; DEBOEVER ${ }^{13}, 1984$, MCLEAN $^{45}$, 1998, ROSENSTIEL; LAND; FUJIMOTO ${ }^{78}$, 2002, STEIN; KUWATA $^{92}$, 1977). Por outro lado, torna-se extremamente difícil a comparação entre valores de resistência à fratura encontrados na literatura devido a diferentes metodologias e materiais usados (CASTELLANI et al. ${ }^{10}$, 1994, JOSEPHSON et al. $^{34}$, 1991, KU; PARK; YANG ${ }^{37}, 2002$, O'BOYLE et al. $^{63}$, 1997, POLIKET; CHICHE; FINGER ${ }^{68}$, 2004, ULUSOY; TOKSAVUL ${ }^{97}$, 2002).

Quando se analisou a resistência à fratura levando-se em conta 0 material, a infra-estrutura metálica com reforço (237,637 kgf) proporcionou valores $38,5 \%$ maiores que o grupo sem reforço (171,738 kgf). Esses valores demonstraram a importância do desenho na resistência à fratura. Esse mesmo aspecto pode ser comprovado ao se analisar a resistência à fratura das coroas 
ceramocerâmicas, nas quais os valores do grupo com reforço foram 36,5\% maiores do que as sem reforço. Todas essas diferenças foram estatisticamente significantes $(p<0,05)$ (Tabela 5.3) e demonstraram a superioridade das características mecânicas da infra-estrutura de níquel-cromo quando comparadas as de In-Ceram Alumina, independentemente do seu desenho, mas que se acentua com a ausência do reforço lingual e poste proximal. Esta ocorrência leva ao aumento da possibilidade de fraturas em condições fisiológicas e, obviamente, potencializa as chances dessa ocorrência na presença de hábitos parafuncionais, mesmo que eventuais.

As coroas com infra-estruturas metálicas com reforço apresentaram média 154,8\% maior que as coroas ceramocerâmicas com infra-estrutura sem reforço $(237,637$ e 93,914 kgf, respectivamente). Por outro lado, as coroas metalocerâmicas sem reforço apresentaram valores médios 34,6\% maiores do que as coroas ceramocerâmicas com reforço, demonstrando que mesmo em condições ideais de desenho, a presença do metal é preponderante para a resistência.

Além de apresentar a menor resistência à fratura entre os quatro grupos analisados, as coroas ceramocerâmicas sem reforço apresentaram também o maior desvio padrão entre os grupos (17, 345 kgf) e diferenciaramse no tipo de fratura (cominutiva); o desvio padrão nos demais grupos foi praticamente igual (Tabela 5.2).

Já em 1988, McLEAN; KEDGE ${ }^{53}$, demonstraram que nenhum sistema ceramocerâmico igualava a resistência à fratura dos sistemas metalocerâmicos, embora tenham utilizado outros tipos de cerâmicas na infraestrutura em seu estudo. JOSEPHSON et al. ${ }^{34}$, 1991, PRÖBSTER ${ }^{70}, 1992$, GREY; PIDDOCK; WILSON ${ }^{23}$, 1993, STRUB; BESCHNIDT ${ }^{94}$, 1998, e KU; PARK; YANG ${ }^{37}$, 2002, trabalhando com restaurações metalocerâmicas e ceramocerâmicas sem reforço, também encontraram valores maiores de resistência à fratura para as coroas metalocerâmicas. ORAM; DAVIES; CRUICKSHANKS-BOYD ${ }^{65}$, 1984, JOSEPHSON et al. $^{35}$, 1985, McLEAN; KEDGE $^{53}, 1988$, McLEAN $^{48}, 1990$, e PROOS et al. ${ }^{74}, 2002$, consideram que as propriedades físicas das infra-estruturas metalocerâmicas são totalmente diferentes da ceramocerâmicas. Isso permite afirmar que mesmo com muitos avanços em técnicas e materiais empregados na elaboração das coroas 
ceramocerâmicas, estas ainda apresentam amplas desvantagens mecânicas em relação ao sistema metalocerâmico.

Vale ressaltar que os resultados obtidos neste trabalho estão em contradição com os dados obtidos por GREY; PIDDOCK; WILSON ${ }^{23}$, 1993, e CASTELLANI et al. ${ }^{10}$, 1994, que indicam ter as coroas do sistema In-Ceram alumina resistência similar a das coroas metalocerâmicas, embora estes autores tenham utilizado metodologias diferentes.

O grupo de coroas ceramocerâmicas sem reforço (Grupo 4) apresentou valor médio de resistência à fratura de 93,914 kgf; os trabalhos de PROBSTER $^{70}$, 1992, GREY; PIDDOCK; WILSON ${ }^{23}$, 1993, YOSHINARI; DÉRAND ${ }^{108}, 1994$, e STRUB; BESCHNIDT ${ }^{94}, 1998$, obtiveram valores médios de 98,308 kgf, 112,178 kgf, 108,098 kgf e 50,480 kgf, respectivamente, para coroas fabricadas com o mesmo material. Porém, como as metodologias não foram similares à utilizada no presente trabalho, fica difícil fazer uma comparação. Com relação ao grupo de coroas ceramocerâmicas com reforço (grupo 3) o valor médio de resistência à fratura foi de 127,588 kgf, superior aos valores citados acima.

Com relação ao tipo de fratura, nas coroas metalocerâmicas ela ocorreu exclusivamente na porcelana de revestimento, com ou sem exposição do metal ou opaco, independentemente da presença do reforço. Apesar disso, quando sem reforço, as fraturas deste grupo aparentemente apresentavam-se maiores e com maior exposição do metal da infra-estrutura. Algumas dessas fraturas se ocorressem clinicamente, seriam reparáveis por meio de ácido fluorídrico, silano, adesivo, opaco e resina composta.

Por outro lado, as fraturas em todas as coroas ceramocerâmicas com reforço incluíram a porcelana de revestimento e a infra-estrutura de alumina, nenhuma delas reparáveis por técnica adesiva restauradora. $\mathrm{Na}$ ausência de reforço, a força de compressão axial provocou estilhaçamento da porcelana de revestimento e da infra-estrutura de todas as coroas, gerando pequenos fragmentos típicos de uma fratura cominutiva. Essas fraturas foram provavelmente semelhantes às descritas por DICKINSON et al. ${ }^{16}$, 1989, e CASTELLANI et al. ${ }^{10}$, 1994, denominadas de "catastróficas".

A diferença no tipo de fratura pode também ser creditada às diferentes características mecânicas dos 2 materiais (níquel-cromo e In-Ceram 
Alumina), incluindo o módulo de elasticidade (CAMPBELL ${ }^{9}, 1989$, CASTELLANI et al. ${ }^{10}$, 1994), porosidade $\left(\right.$ MCLEAN $^{49}, 1983$, MUNOZ et al. ${ }^{59}$, 1982), geometria (CAMPBELL $\left.{ }^{9}, 1989\right)$ e espessura $\left(\right.$ RILEY $\left.^{77}, 1977\right)$ que conformavam a infra-estrutura dos corpos de prova.

O alto módulo de elasticidade das infra-estruturas metálicas aumenta a resistência ao estresse que limita a extensão da fratura às camadas superficiais (CASTELLANI et al. ${ }^{10}$, 1994). Quando comparados com ligas metálicas, os materiais cerâmicos geralmente apresentam menores valores para o módulo de elasticidade (CAMPBELL ${ }^{9}$, 1989) e, assim, eles oferecem menor resistência ao estresse favorecendo a fratura em todas as camadas (CASTELLANI et al. ${ }^{10}$, 1994).

Vários trabalhos laboratoriais (CASTELLANI et al. ${ }^{10}, 1994$, LUND; BARBER $^{40}$, 1992, ULUSOY; TOKSAVUL ${ }^{97}$, 2002, WEBBER; MCDONALD; KNOWLES ${ }^{105}$, 2003) são unânimes em afirmar a importância do desenho da infra-estrutura na resistência à fratura de coroas metalocerâmicas e sugerem que nas próteses sejam respeitados os critérios de desenho estabelecidos na literatura (BERGER ${ }^{6}, 1989, \quad$ CHICHE; PINAULT ${ }^{11}, 1994$, HOBO; SHILLINGBURG ${ }^{29}, 1973$, KORNFELD $^{36}, 1974$ MILLER $^{56}, 1977$, MUMFORD $^{58}$, 1965, NAYLOR ${ }^{61}$, 1992, RAMOS JUNIOR; BATISTA; MIRANDA ${ }^{76}, 1997$, ROSENSTIEL; LAND; FUJIMOTO ${ }^{78}$, 2002, SOZIO ${ }^{90}, 1977$, STEIN; KUWATA ${ }^{92}$, 1977, STRAUSSBERG; KATZ; KUWATA ${ }^{93}, 1966$. WEISS $\left.^{106}, 1977\right)$.

Assim, a presença do reforço na infra-estrutura parece ser um fator determinante no aumento da resistência à fratura. Os resultados obtidos corroboram as sugestões propostas por McLEAN ${ }^{45}, 1998$, MENDES et al. ${ }^{55}$, 2006, e BOTTINO; FARIA; BUSO7, 2006 e indicam a necessidade de se cumprir a indicação dos elementos de reforço na infra-estrutura, como a cinta lingual e o poste proximal, para melhorar as características mecânicas de resistência à fratura das coroas ceramocerâmicas.

Deve ser ressaltado que os valores de resistência à fratura das coroas ceramocerâmicas obtidos neste trabalho (Tabela 5.1) são suficientes para resistir às forças mastigatórias funcionais, que podem variar de 5 a $25 \mathrm{kgf}$ na região anterior e de 45 a 90 kgf na região de primeiro molar (MANNS; MIRALLES; PALAZZI ${ }^{42}$, 1979, WALTIMO; KONONEN ${ }^{102}$, 1993, WALTIMO; KONONEN ${ }^{103}$, 1995). Entretanto, torna-se difícil, como em muitos estudos 
laboratoriais, extrapolar os resultados obtidos para aplicações diretas em situações clínicas.

Assim, enquanto não forem executadas mais pesquisas confirmando que as coroas ceramocerâmicas são clinicamente eficientes a longo prazo, deve-se ponderar ou até mesmo evitar indicá-las para situações de risco aumentado, tais como: 1) bruxismo, 2) prótese fixas anteriores de mais de 3 elementos, 3) próteses fixas posteriores, 4) oclusão desfavorável e 5) força de mordida superior à habitual (BOTTINO; FARIA; BUSO ${ }^{7}, 2006$, VITA $^{100}$, 2005). Atenção deve ser dada aos pacientes saudáveis e portadores de restaurações ceramocerâmicas, que poderiam desenvolver, posteriormente, um hábito parafuncional.

Convém citar, ainda, que as situações laboratoriais reais nem sempre respeitam as recomendações determinadas pelos fabricantes (VITA ${ }^{100}$, 2005) confeccionando infra-estruturas com espessura menor que a indicada, e as sugeridas na literatura, como a colocação de reforço nas infra-estruturas (BOTTINO; FARIA; BUSO ${ }^{7}, 2006$, McLEAN $^{45}, 1998$, MENDES et al. ${ }^{55}$, 2006).

Embora esta pesquisa tenha trazido dados relevantes sobre a resistência à fratura das coroas metalocerâmicas e das ceramocerâmicas utilizando diferentes desenhos na infra-estrutura, deve ser salientado que o teste de resistência à fratura foi realizado aplicando-se uma única carga estática. Este tipo de teste é usado quando se deseja conhecer o comportamento de um material submetido a deformações grandes e permanentes. Porém, recomenda-se que em próximas pesquisas de resistência à fratura sejam utilizados testes dinâmicos, como por exemplo, avaliando a capacidade do material de suportar, sem se romper, carregamentos repetitivos e/ou cíclicos, visando a obtenção de mais informações que possibilitem o sucesso clínico a longo prazo dos materiais e desenhos propostos.

Pelo fato de ser relativamente recente o emprego das cerâmicas IPS Empress, In-Ceram e Procera nas infra-estruturas (MENDES et al. ${ }^{55}, 2006$ ), poucos estudos de avaliação clínica a longo prazo existem, tornando-se necessário o desenvolvimento de mais pesquisas para orientar o cirurgiãodentista a indicar com segurança este material em prótese. 
Os resultados desta pesquisa e os disponíveis na literatura (ANDERSSON; ODEN ${ }^{2}, 1993$, BERGER $^{6}, 1989$, CHICHE; PINAULT ${ }^{11}, 1994$, CRAIG; EL-EBRASHI; PEYTON ${ }^{14}$, 1971, GREY; PIDDOCK; WILSON ${ }^{23}, 1993$, HOBO; SHILLINGBURG ${ }^{29}$, 1973, KUWATA ${ }^{38}$, 1988, McLAREN; WHITE ${ }^{44}$, 2000, McLEAN ${ }^{45}$, 1998, McLEAN ${ }^{46}, 2001$, McLEAN; HUGHES ${ }^{51}, 1965$, MCLEAN et al. $^{52}$, 1978, MCLEAN; KEDGE ${ }^{54}$, 1987, MILLER ${ }^{56}, 1977$, MUMFORD $^{58}, 1965$, PROBSTER $^{70}, 1992$, PROBSTER $^{71}, 1993$, PROBSTER $^{72}$, 1996, PROBSTER; DIEHL ${ }^{73}$, 1992, ROSENSTIEL; LAND; FUJIMOTO ${ }^{78}, 2002$, SEGAL ${ }^{81}, 2001$, SGRÒ ${ }^{84}$, 2002, SHELBY ${ }^{85}, 1962$, SMYD $^{89}, 1948$, SMYD $^{88}$, 1952, SOZIO ${ }^{90}$, 1977, STEIN; KUWATA ${ }^{92}$, 1977, STRAUSSBERG; KATZ; KUWATA $^{93}$, 1966, STRUB; BESCHNIDT ${ }^{94}$, 1998, WEISS ${ }^{106}, 1977$, YOSHINARI; DÉRAND ${ }^{108}$, 1994) permitem afirmar que o conhecimento do desenho da infra-estrutura nas restaurações indiretas, e o desenvolvimento de porcelanas mais resistentes, como Procera AllCeram, Procera AllZircon, sistema Lava, Cercon, assim como os materiais fabricados a partir de Yttria de zircônia parcialmente estabilizada (3Y-TZP) (GUAZZATO et al. ${ }^{25}$, 2004, HAGMANN; MARINELLO; ZITZMANN ${ }^{27}$, 2006, RAIRGRODSKI ${ }^{75}, 2004$, VEDOVATO; YASUDA ${ }^{99}$, 2006, WEBBER; MCDONALD; KNOWLES ${ }^{105}$, 2003) são elementos significativos que favoreceriam a elaboração de coroas ceramocerâmicas com melhores características mecânicas de resistência à fratura.

As restaurações ceramocerâmicas são sistemas que têm como objetivo substituir os sistemas metalocerâmicos, entretanto ainda carecem de muitas características mecânicas que limitam sua indicação clínica, principalmente para os dentes posteriores. Ampliando-se as pesquisas clínicas e de laboratório que envolvam as restaurações ceramocerâmicas pode-se conseguir um aperfeiçoamento máximo do sistema, que apresenta, a priori, grande vantagem do ponto de vista estético. 
7 - CONCLUSÕES 


\section{7 - CONCLUSÕES}

De acordo com os resultados obtidos e após a análise estatística, pôde-se concluir que:

7.1 A presença do reforço (cinta lingual e poste proximal) nas infraestruturas resultou em aumento da resistência à fratura.

7.2 As infra-estruturas das coroas metalocerâmicas com reforço apresentaram a maior resistência à fratura entre os grupos testados.

7.3 As infra-estruturas das coroas metalocerâmicas com ou sem reforço, apresentaram os maiores valores de resistência à fratura.

7.4 O menor valor de resistência à fratura ocorreu com as infraestruturas de alumina, sem reforço.

7.5 As coroas metalocerâmicas com ou sem reforço sofreram fraturas conservativas na porcelana de revestimento, enquanto as coroas ceramocerâmicas sofreram fraturas catastróficas e cominutivas (infra-estruturas sem reforço). 


\section{REFERÊNCIAS BIBLIOGRÁFICAS}

1. Adair PJ, Grossman D. The castable ceramic crown. Int J Periodontics Restorative Dent 1984;4(2):32-46.

2. Andersson M, Odén A. A new all-ceramic crown. A dense-sintered, highpurity alumina coping with porcelain. Acta Odontol Scand 1993;51(1):5964.

3. Anusavice KJ. Cerâmicas Odontológicas. In: Anusavice KJ, editor. Phillips, materiais dentários. São Paulo: Elsevier; 2005. p. 619-77.

4. Araújo CRP. Formas e características das infra-estruturas para próteses metalocerâmicas. In: Pegoraro LF, editor. Prótese Fixa. São Paulo: EAP•APCD; 2000. p. 205-18.

5. Ban S, Anusavice KJ. Influence of test method on failure stress of brittle dental materials. J Dent Res 1990;69:1791-9.

6. Berger R. Esthetic and physiologic considerations in metallic framework design. Dent Clin North Am 1989;33(2):293-9.

7. Bottino MA, Faria R, Buso L. Sistema In-Ceram na atualidade. In: Dib LL, Saddy MS., editor. Atualização clínica em odontologia Estética e Prótese. São Paulo: Artes Medicas; 2006. p. 411-45.

8. Bottino MA, Giannini V, Miyashita E, Quintas AF. Materiais cerâmicos. In: Bottino MA, editor. Estética em Reabilitação Oral: Metal Free. São Paulo: Artes Médicas; 2000. p. 211-331.

9. Campbell SD. A comparative strength study of metal ceramic and allceramic esthetic materials: Modulus of rupture. J Prosthet Dent 1989;62(4):476-9.

10. Castellani D, Baccetti T, Giovannoni A, Bernardini UD. Resistence to fracture of metal ceramic and all-ceramic crowns. Int J Prosthodont 1994;7:149-54.

11. Chiche GJ, Pinault A. All-Ceramic crowns and foils corwns. In: Chiche GJ, Pinault A, editors. Esthetics of anterior fixed prosthodontics. Singapore: Quintessence Books; 1994. p. 97-113. 
12. Christensen GJ. Ceramic vs. porcelain fused to metal crowns. J Am Dent Assoc 1994;125(1):311-4.

13. Coornaert J, Adriaens P, DeBoever J. Long-term clinical study of porcelain-fused-to-gold restorations. J Prosthet Dent 1984;51(3):338-42.

14. Craig RG, El-Ebrashi MK, Peyton FA. Stress distribution in porcelainfused-to-gold crowns and preparations constructed with photoelastic plastic. J Dent Res 1971;50(5):1278-83.

15. DeHoff $\mathrm{PH}$, Anusavice $\mathrm{KJ}$. Effect of metal design on marginal distortion of metal-ceramic crowns. J Dent Res 1984;63(11):1327-31.

16. Dickinson AJG, Moore BK, Harris RK, Dykema RW. A comparative study of the strength of aluminous porcelain and all-ceramic crowns. J Prosthet Dent 1989;61(1):297-304.

17. Donovan TE, Chee WWL. Conservative indirect restorations for posterior teeth. Cast versus bonded ceramic. Dent Clin North Am 1993;37(3):43343.

18. Farah JW, Craig RG. Distribution of stresses in porcelain-fused-to-metal and porcelain jacket crowns. J Dent Res 1975;54(2):255-61.

19. Faucher RR, Nicholls Jl. Distortion related to margin design in porcelainfused-to-metal restorations. J Prosthet Dent 1980;43(2):149-55.

20. Fradeani M, Redemagni M. An 11-year clinical evaluation of leucitereinforced glass-ceramic crowns: A retrospective study. Quintessence Int 2002;33(7):503-10.

21. Gardner FM, Tillman-McCombs KW, Gaston ML, Runyan DA. In vitro failure load of metal-collar margins compared with porcelain facial margins of metal-ceramic crowns. J Prosthet Dent 1997;78(1):1-4.

22. Giordano II R. A comparison of all-ceramic restorative systems: Part 2 Gen Dent 2000;48(1):38-45.

23. Grey NJA, Piddock V, Wilson MA. In vitro comparison of conventional crowns and a new all-ceramic system. J Dent 1993;21:47-51.

24. Guazzato M, Pross K, Quach L, Swain MV. Mechanical properties of inceram alumina and inceram zirconia. J Dent Res 2001;80:640.

25. Guazzato M, Pross K, Quach L, Swain MV. Strength, reliability and mode of fracture of bilayered porcelain/zirconia (Y-TZP) dental ceramics. Biomaterials 2004;25:5045-52. 
26. Guerra SM. Avaliação do desajuste cervical de coroas metalocerâmicas, obtidas a partir da fundição com cinco ligas de $\mathrm{Ni}-\mathrm{Cr}$ e duas porcelanas odontológicas. Bauru: Universidade de São Paulo; 1990.

27. Hagmann E, Marinello CP, Zitzmann NU. Fracture resistance of Procera Allceram depending on the framework design--an in vitro study. Schweiz Monatsschr Zahnmed 2006;116(1):25-32.

28. Hobo S. Accuracy of porcelain occlusals. In: McLean JW, editor. Dental ceramics: Proceedings of The First International Symposium on Ceramics. Chicago: Quintessence; 1983. p. 313-35.

29. Hobo S, Shillingburg HT. Porcelain fused to metal: Tooth preparation and coping design. J Prosthet Dent 1973;30(1): 28-36.

30. Hojjatie B, Anusavice KJ. Three-dimensional finite element analysis of glass-ceramic dental crowns. J Biomech 1990;23(11):1157-66.

31. Holand W, Schweiger M, Frank M, Rheingberg V. Comparison of the microstructure and properties of the IPS empress 2 and the IPS empress glass-ceramics. J Biomed Mater Res 2000;53:297-303.

32. Hondrum SO. A review of the strength properties of dental ceramics. J Prosthet Dent 1992;67(6):859-65.

33. Hudson JT. Some physical properties of three dental porcelains. J Prosthet Dent 1959;9(2):325-35.

34. Josephson BA, Schulman A, Dunn ZA, Hurwitz W. A compressive strength study of complete ceramic crowns. Part II. J Prosthet Dent 1991;65(3):388-91.

35. Josephson BA, Schulman A, Dunn ZA, Hurwitz W. A compressive strength study of an all-ceramic crown. J Prosthet Dent 1985;53(3):3013.

36. Kornfeld M. Essential and fundamental factors in crown and bridge prosthodontics. In: Mouth rehabilitation clinical and laboratory procedures St. louis: Mosby; 1974. p. 248-345.

37. Ku C, Park S, Yang H. Comparison of the fracture strength of metalceramic crowns and three ceromer crowns. J Prosthet Dent 2002;88(2):170-5.

38. Kuwata M. Fabricación de la sub-estructura metálica soporte de la porcelana. In: Kuwata $\mathrm{M}$, editor. Atlas a color de tecnologia en metal- 
cerámica. Caracas: Actualidades Médico-Odontólogicas Latinoamérica C.A.; 1988. p. 235-312.

39. Land C. Porcelain dental arts. Dental Cosmos 1903;45:615-20.

40. Lund PS, Barber BA. The effect of porcelain veneer extension on strength of metal ceramic crowns. Int J Prosthodont 1992;5(3):237-43.

41. Magne P, Peraksi N, Belser UC, Krejci I. Stress distribution of inlayanchored adhesive fixed partial dentures: A finite element analysis of the influence of restorative materials and abutment preparation design. $\mathrm{J}$ Prosthet Dent 2002;87(5):516-27.

42. Manns A, Miralles R, Palazzi C. EMG, bite force and elongation of the masseter muscle under isometric voluntary contractions and variations of vertical dimension. J Prosthet Dent 1979;42(6):674-82.

43. Marker JM, Goodkind RJ, Gerberich WW. The compressive strength of nonprecious versus precious ceramometal restorations with various frame designs. J Prosthet Dent 1986;55(5):560-7.

44. McLaren EA, White SN. Survival of In-Ceram crowns in a private practice: A prospective clinical trial. J Prosthet Dent 2000;83(2):216-22.

45. McLean JW. Modern dental ceramics. In: McLean JW, editor. Advances in Clinical Prosthodontics. Padova: Piccin Nuova Libraria S.p.A.; 1998. p. 1-44.

46. McLean JW. Evolution of dental ceramics in the twentieth century. J Prosthet Dent 2001;85(1):61-6.

47. McLean JW. High-alumina ceramics for bridge pontic construction. Brith Dent J 1967;123(12):571-7.

48. McLean JW. The failed restoration: Causes of failure and how to prevent them. Int Dent J 1990;40(6):354-8.

49. McLean JW. Dental ceramics: Proceedings of the first international symposium on ceramics. Chicago: Quintessence 1983.

50. McLean JW. Long-term esthetic dentistry. Quintessence Int 1989;20(10):701-8.

51. McLean JW, Hughes TH. The reinforcement of dental porcelain with ceramic oxides. Brith Dent J 1965;119(6):251-67.

52. McLean JW, Jeansonne EE, Bruggers H, Lynn DB. A new metal-ceramic crown. J Prosthet Dent 1978;40(3):273-87. 
53. McLean JW, Kedge MI. High-strength ceramics. Quintessence Int 1987;18(2):97-106.

54. McLean JW, Kedge MI. High-strength ceramics. In: Preston JD, editor. Perspectives in dental ceramics: Proceedings of The Fourth International Symposium on Ceramics. Chicago: Quintessence; 1988. p. 153-65.

55. Mendes WB, Bonfante G, Bonfante EA, Consani S. Tendências atuais da prótese fixa. In: Dib LL, Saddy MS., editor. Atualização clínica em odontologia Estética e Prótese. São Paulo: Artes Medicas; 2006. p. 387409.

56. Miller LL. Framework design in ceramo-metal restorations. Dent Clin North Am 1977;21(4):699-716.

57. Muia PJ. Porcelain fracture: Causes, repair and prevention. In: MUIA PJ, editor. Esthetic Restorations. Chicago: Quintessennce books; 1993. p. 187-208.

58. Mumford G. The porcelain fused to metal restoration. Dent Clin North Am 1965:241-9.

59. Munoz CA, Goodacre CJ, Moore BK, Dykema RW. A comparative study of the strength of aluminous porcelain jacket crowns constructed with the conventional and twin foil techniques. J Prosthet Dent 1982;48:271-81.

60. Nally JN, Farah JW, Craig RG. Experimental stress analysis of dental restorations. Part IX. Two-dimensional photoelastic stress analysis of porcelain bonded to gold crowns. J Prosthet Dent 1971;25(3):307-16.

61. Naylor WP. Essentials of metal ceramic substructure design. In: Naylor WP, editor. Introduction to metal ceramic technology. Chicago: Quintessence; 1992. p. 43-64.

62. Neiva G, Yaman P, Dennison JB, Razzog ME, Lang BR. Resistance to fracture of three all-ceramic systems. J Esthet Dent 1998;10(2):60-6.

63. O'Boyle KH, Norling BK, Cagna DR, Phoenix DP. An investigation of the new metal framework design for metal ceramic restorations. J Prosthet Dent 1997;78(3):295-301.

64. Odén A, Andersson M, Krystek-Ondracek I, Magnusson D. Five-year evolution of Procera AllCeram crowns. J Prosthet Dent 1998;80:450-6.

65. Oram DA, Davies EH, Cruickshanks-Boyd DW. Fracture of ceramic and metalloceramic cylinders. J Prosthet Dent 1984;52(1):221-30. 
66. Pallis K, Griggs JA, Woody RD, Guillen GE, Miller AW. Fracture resistance of three all-ceramic restorative systems for posterior applications. J Prosthet Dent 2004;91(6):561-9.

67. Philp GK, Burkl CE. Compressive strengths of conventional, twin foil, and all-ceramic crowns. J Prosthet Dent 1984;52(1):215-20.

68. Poliket N, Chiche G, Finger IM. In vitro fracture strength of teeth restored with different all-ceramic crown system. J Prosthet Dent 2004;92(5):4915.

69. Pospiech P, Rammelsberg P, Goldhofer G, Gernet W. All-ceramic resinbonded bridges. A 3-dimensional finite-element analysis study. Eur J Oral Sci 1996;104:390-5.

70. Probster L. Compressive strength of two modern all-ceramic crowns. J Prosthodont 1992;5(5):409-14.

71. Probster L. Survival rate of In-Ceram restorations. Int J Prosthodont 1993;6(3):259-63.

72. Probster L. Four year clinical study of glass-infiltrated, sintered alumina crowns. J Oral Rehabil 1996;23(3):147-51.

73. Probster L, Diehl J. Slip-casting alumina ceramics for crown and bridge restorations. Quintessence Int 1992;23(1):25-31.

74. Proos KA, Swain MV, Ironside J, Steven GP. Finite element analysis studies of an all-ceramic crown on a first premolar. Int J Prosthodont 2002;15(4):404-12.

75. Rairgrodski AJ. Contemporary all-ceramic fixed partial dentures: a review. Dent Clin North Am 2004;48:531-44.

76. Ramos Junior L, Batista JG, Miranda ME. Características da infraestrutura para restaurações metalocerâmicas. Odonto Pope 1997;1(3):160-9.

77. Riley EJ. Ceramo-metal restoration. Sate of the science. Dent Clin North Am 1977;21:669-82.

78. Rosenstiel SF, Land MF, Fujimoto J. Design da estrutura e seleção do metal para as restaurações metalocerâmicas. In: Rosenstiel SF, Land MF, Fujimoto J, editor. Próteses fixa contemporânea. São Paulo: Santos; 2002. p. $488-512$. 
79. Sadoun M. Slip cast alumina ceramics. In: GC International Conference on Dental Ceramics; 1989 September 13; Leed Castle, England; 1989.

80. Scholes SR. Modern Glass Practice. Chicago: Industrial Publications; 1952.

81. Segal BS. Retrospective assessment of 546 all-ceramic anterior and posterior crowns in a general practice. J Prosthet Dent 2001;85(6):54450.

82. Seghi RR, Daher T, Caputo A. Relative flexural strength of dental restorative ceramics. Dent Mat 1990;6:181-4.

83. Seghi RR, Sorensen JA. Relative flexural strength of six new ceramic materials. Int J Prosthdont 1995;8(3):239-46.

84. Sgrò S. Principles of the metal framework design in metal-ceramic reconstructions. Quintessence of Dental Technology 2002;25:21-52.

85. Shelby DS. Practical considerations and design of the porcelain fused to metal. J Prosthet Dent 1962;12(3):542-8.

86. Shillingburg HT, Hobo S, Fisher DW. Preparation design and margin distortion in porcelain-fused-to-metal restorations. J Prosthet Dent 1973;29(3):276-84.

87. Silver M, Klein G, Howard MC. An evaluation and comparison of porcelains fused to cast metals. J Prosthet Dent 1960;10(6):1055-64.

88. Smyd ES. Mechanics of dental structures: Guide to teaching dental engineering at undergraduate level. J Prosthet Dent 1952;2(5):668-92.

89. Smyd ES. Dental engineering. J Dent Res 1948;27(6):649-60.

90. Sozio RB. The marginal aspect of the ceramo-metal restoration: the collarless ceramo-metal restoration. Dent Clin North Am 1977;21(4):787801.

91. Stein RS. Periodontal dictates for esthetic ceramometal crowns. J Am Dent Assoc 1987;115:63.

92. Stein RS, Kuwata M. A dentist and a dental technologist analyze current ceramo-metal procedures. Dent Clin North Am 1977;21(4):729-49.

93. Straussberg G, Katz G, Kuwata M. Design of gold supporting structures for fused porcelain restorations. J Prosthet Dent 1966;16(5):928-36.

94. Strub JR, Beschnidt SM. Fracture strength of 5 different all-ceramic crown systems. Int J Prosthodont 1998;11(6):602-9. 
95. Tesk JA, Anusavice KJ. Summary of conference on design of dental prostheses. Dent Mater 1988;4(1):49-50.

96. Thompson VP, Rekow DE. Dental ceramics and the molar crown testing ground. J Appl Oral Sci 2004;12:26-36.

97. Ulusoy M, Toksavul S. Fracture resistance of five different metal framework designs for metal-ceramic restorations. Int J Prosthodont 2002;15(6):571-4.

98. Van der Zel JM, Vlaar S, Ruiter WJ, Davidson C. The CICERO System for CAD/CAM fabrication of full-ceramic crowns. J Prosthet Dent 2001;85(3):261-7.

99. Vedovato E, Yasuda SH. Sistema Procera. In: Dib LL, Saddy MS., editor. Atualização clínica em Odontologia Estética e Prótese. São Paulo: Artes Medicas; 2006. p. 557-77.

100. Vita. Vita In-Ceram ALUMINA. In: Vita System; 2005.

101. Wagner WC, Chu TM. Biaxial flexural strength and indentation fracture toughness of three new dental core ceramics. J Prosthet Dent 1996;76(2):140-4.

102. Waltimo A, Kononen M. A novel bite force recorder and maximal isometric bite force values for healthy young adults. Scand J Dent Res 1993;101(3):171-5.

103. Waltimo A, Kononen M. Maximal bite force and its association with signs and symptoms of craniomandibular disorder in young finnish nonpatients. Acta Odontol Scand 1995;53(4):254-8.

104. Warpeha WS, Goodkind RJ. Design and technique variables affecting fracture resistance of metal-ceramic restorations. J Prosthet Dent 1976;35(3):291-8.

105. Webber B, McDonald A, Knowles JC. An in vitro study of the compressive load at fracture of procera allceram crowns whit varying thickness of veneer porcelain. J Prosthet Dent 2003;89(2):154-60.

106. Weiss PA. New design parameters: Utilizing the properties of nickelchromium super alloys. Dent Clin North Am 1977;21(4):769-85.

107. Wohlwend A, Strub JR, Scharer P. Metal ceramic and all-porcelain restorations: Current considerations. Int J Prosthodont 1989;2(1). 
108. Yoshinari M, Dérand T. Fracture strength of all-ceramic crowns. Int $\mathrm{J}$ Prosthodont 1994;7(4):329-38.

109. Zeng K, Oden A, Rowcliffe D. Flexure tests on dental ceramics. Int J Prosthodont 1996;9:434-9. 
ABSTRACT 


\author{
ABSTRACT \\ FRACTURE RESISTANCE OF METAL-CERAMIC AND ALL-CERAMIC \\ CROWNS MADE WITH AND WITHOUT REINFORCED COPING DESIGN
}

\begin{abstract}
Metal-ceramic restorations present reports of long-term clinical success, and the characteristics of reinforcement coping (lingual collar and buttressing shoulder) seem to be of great importance for this success. These reinforcements are often absent in all-ceramic coping restorations. The aim of the current study was to evaluate and compare the in vitro fracture resistance of metal-ceramic and In-Ceram Alumina all-ceramic crowns, with and without reinforced coping design. Forty crowns were fabricated and divided into four groups ( $n=10)$ : group 1, metal-ceramic crown with reinforced coping design; group 2, metal-ceramic crown without reinforced coping design; group 3, allceramic crown with reinforced coping design and group 4, all-ceramic crown with out reinforced coping design. The forty crowns were cemented on stainless steel dies and axially loaded in a universal testing machine until fracture occurred, and the maximum load (kgf) was recorded. Data were analyzed by one-way analysis of variance (ANOVA) and Tukey test $(p<0.05)$ The results showed a statistical significant superiority $(p<0.05)$ of the reinforcement coping groups (237.637 kgf for metalo-ceramic crowns and $127.588 \mathrm{kgf}$ for all-ceramic crowns), regarding to non reinforcement coping groups (171.738 kgf for metalo ceramic crowns and $93.914 \mathrm{kgf}$ for all-ceramic crowns). These founds denote that: (1) crowns made with reinforcement coping had presented greater fracture resistance than those confectioned without it and (2) metal-ceramic crowns had presented greater fracture resistance than all-ceramic crowns.
\end{abstract}

Keywords: All-ceramic crowns. Metal-ceramic crowns. Coping design. Fracture resistance. Lingual collar. Buttressing shoulder. 